\title{
Pre-breeding food habits and condition of ruffed grouse and effects on reproduction in the central and southern Appalachians
}

\author{
C. Robert Long \\ West Virginia University
}

Follow this and additional works at: https://researchrepository.wvu.edu/etd

\section{Recommended Citation}

Long, C. Robert, "Pre-breeding food habits and condition of ruffed grouse and effects on reproduction in the central and southern Appalachians" (2007). Graduate Theses, Dissertations, and Problem Reports. 2520.

https://researchrepository.wvu.edu/etd/2520

This Thesis is protected by copyright and/or related rights. It has been brought to you by the The Research Repository @ WVU with permission from the rights-holder(s). You are free to use this Thesis in any way that is permitted by the copyright and related rights legislation that applies to your use. For other uses you must obtain permission from the rights-holder(s) directly, unless additional rights are indicated by a Creative Commons license in the record and/ or on the work itself. This Thesis has been accepted for inclusion in WVU Graduate Theses, Dissertations, and Problem Reports collection by an authorized administrator of The Research Repository @ WVU. For more information, please contact researchrepository@mail.wvu.edu. 
PRE-BREEDING FOOD HABITS AND CONDITION OF RUFFED GROUSE AND EFFECTS ON REPRODUCTION IN THE CENTRAL AND SOUTHERN

APPALACHIANS

C. ROBERT LONG

A Thesis Submitted to the Davis College of Agriculture, Forestry, and Consumer Sciences at West Virginia University in Partial Fulfillment of the Requirements for the Degree of

MASTER OF SCIENCE

in

Wildlife and Fisheries Resources

Division of Forestry and Natural Resources

John W. Edwards, Ph.D., Chair

James T. Anderson, Ph.D.

P. Brett Kenney, Ph.D.

Morgantown, West Virginia

2007

Keywords: Appalachian Mountains, Bonasa umbellus, condition, food habits, nutrition, nutritional ecology, reproduction, ruffed grouse

Copyright 2007 C. Robert Long 


\section{ABSTRACT \\ PRE-BREEDING FOOD HABITS AND CONDITION OF RUFFED GROUSE AND EFFECTS ON REPRODUCTION IN THE CENTRAL AND SOUTHERN APPALACHIANS}

\section{ROBERT LONG}

Previous researchers have hypothesized that low ruffed grouse densities in the central and southern Appalachians may be related to nutritional constraints. Working as part of the Appalachian Cooperative Grouse Research Project (ACGRP), I investigated the pre-breeding food habits and body condition of 432 ruffed grouse from 9 states and explored relations between nutrition of breeding females and productivity in the central and southern Appalachians. The pre-breeding diet of ruffed grouse in the Appalachians differed substantially from grouse in more northern regions and was highly variable among and within sites and years. Grouse feeding on hard mast contained 71-79\% greater fat reserves during the pre-breeding period than grouse feeding on alternate forages. I found evidence to suggest that pre-breeding females in poor condition may decrease reproductive output at the site-level via delayed nesting, smaller clutch size, and reduced chick survival. Chick survival to 5-weeks post-hatch on sites containing females with low fat reserves was $50 \%$ to $65 \%$ lower than on sites containing females with moderate or high fat levels. My findings support the hypothesis that nutrition and condition of breeding females influences the population dynamics of ruffed grouse in the central and southern Appalachians. Because substantial variation in nutritional ecology was evident among regions, land managers should formulate habitat management prescriptions that will fulfill the local nutritional needs of ruffed grouse. 


\section{ACKNOWLEDGMENTS}

Primary funding and personnel were provided by the Kentucky Department of Fish and Wildlife Resources, Maryland Department of Natural Resources (W-61-R), Ohio Department of Natural Resources (W-134-P), Rhode Island Division of Fish and Wildlife (W-23-R), Virginia Department of Game and Inland Fisheries (WE-99-R), West Virginia Division of Natural Resources (W-48-R), and the Richard King Mellon Foundation. Partial funding and additional logistical support for the project was provided by the Ruffed Grouse Society, USFWS Region V Northeast Administrative Funds, George Washington and Jefferson National Forests, MeadWestvaco Corporation, Champlain Foundation, North Carolina Wildlife Resources Commission, Pennsylvania Department of Conservation and Natural Resources, Pennsylvania Game Commission, Coweeta Hydrologic Lab, and the Campfire Conservation Fund. California University of Pennsylvania, Eastern Kentucky University, Fordham University, University of Rhode Island, University of Tennessee, Virginia Tech, and West Virginia University sponsored graduate students working on the cooperative project. I thank the following individuals for their support of the ACGRP: Mark Banker, Buddie Chandler, Dan Dessecker, Mark Ford, Pat Keyser, Scott Klopfer, Roy Kirkpatrick, Tom Lail, John Organ, Mike Seamster, Dave Samuel, Terry Sharpe, Randy Tucker, Jim Vose, Michael Watson, and Gary White.

I thank my graduate committee members Jim Anderson and Brett Kenney for their helpful insight and expertise. I am grateful to John Edwards, my major advisor, for providing opportunity, support, constructive criticism, and a great deal of patience that has and will continue to help me immensely in my career. Gary Norman not only coordinated ACGRP efforts with excellence, but also encouraged, challenged, and guided me in my research and career. He is a role model and friend that I will always be indebted to. I also thank Tom Allen, 
Steve Bittner, Scott Friedhof, Rick Horton, Gary Norman, Mike Seamster, Terry Sharpe, Harry Spiker, Al Stewart, Gordon Warburton, and Keith Warnke for coordinating state grouse collection efforts. Numerous state agency and university personnel provided valuable on-theground collection assistance that allowed this project to succeed. Technicians Seth Lemley and Brandon Scurlock assisted with the arduous task of hand-plucking hundreds of grouse. I also acknowledge Rich Ciaffoni, Pat Devers, Bill Grafton, Bill Guiliano, Bill Harvey, Dave Helon, George Seidel, Susan Slider, and Tammy Webster for contributing to various aspects of my project. My family deserves special thanks for their unwavering support. Finally, I thank my amazing wife, Michelle, who has enabled me to pursue my goals without question and, more importantly, has given me the most treasured things in my life - our 2 wonderful sons, Justin and Jacob. 


\section{TABLE OF CONTENTS}

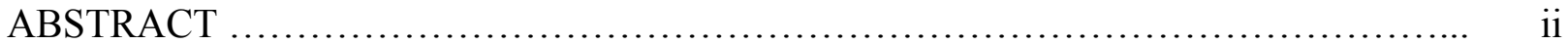

ACKNOWLEDGMENTS ........................................................ iii

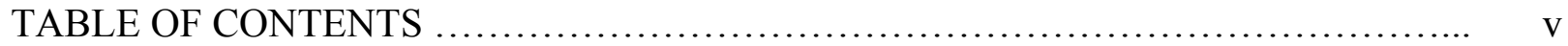

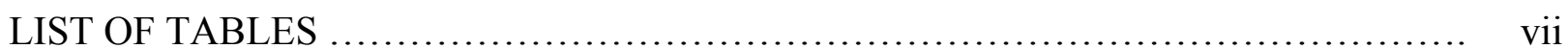

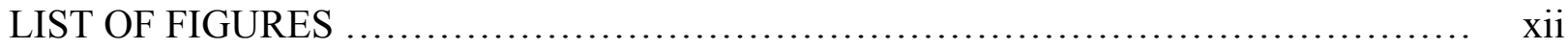

INTRODUCTION ........................................................................ 1

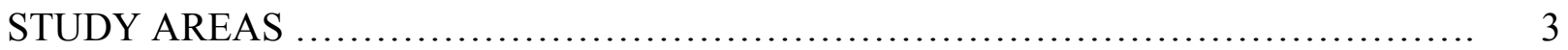

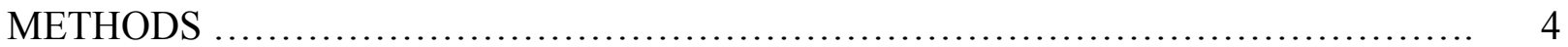

Grouse Collections .............................................................. 4

Carcass Composition........................................................ 5

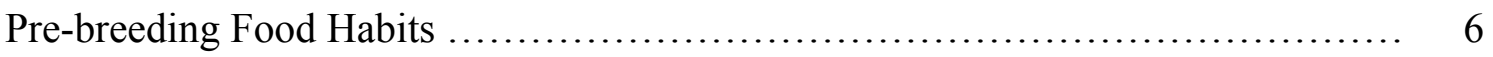

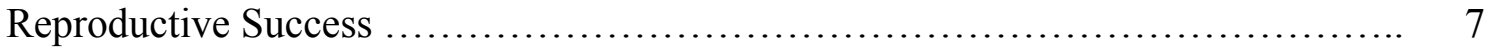

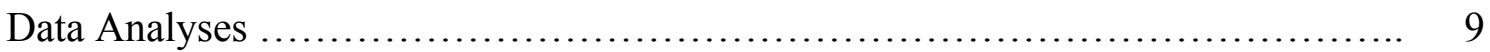

Diet-Condition Relations ............................................ 9

Condition-Reproduction Relations ................................... 11

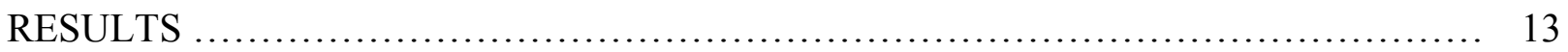

Pre-breeding Food Habits .............................................. 13

Regional Comparisons .............................................. 13

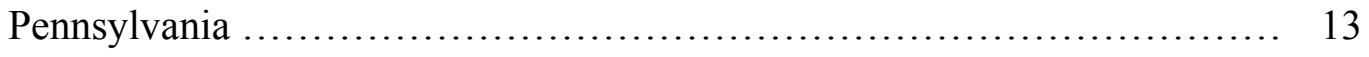

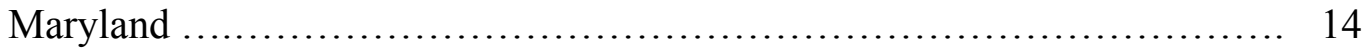

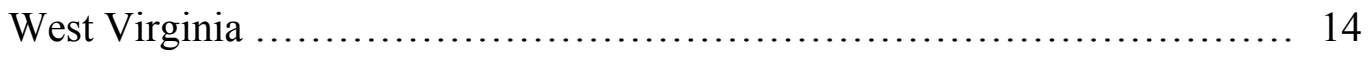

Virginia ............................................................... 15 


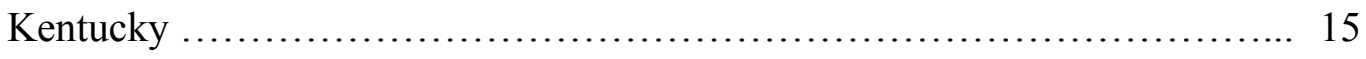

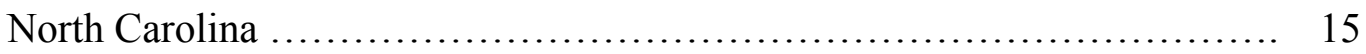

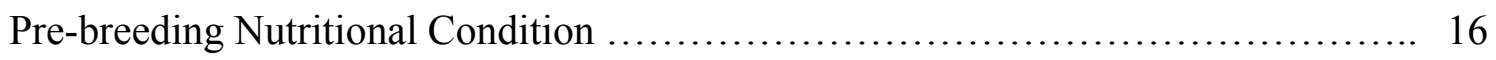

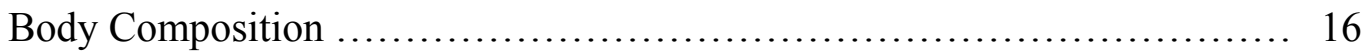

Diet-Condition Relations .............................................. 16

Condition-Reproduction Relations ...................................... 17

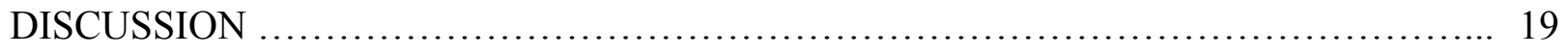

Pre-breeding Food Habits ................................................ 19

Pre-breeding Nutritional Condition.......................................... 23

Effects of Nutrition and Condition on Reproduction ............................. 25

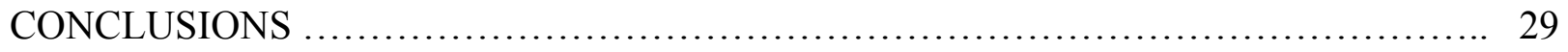

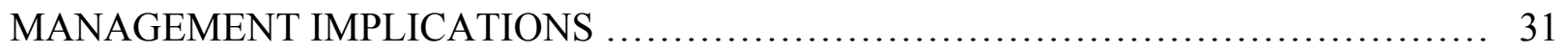

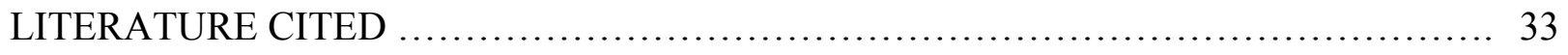

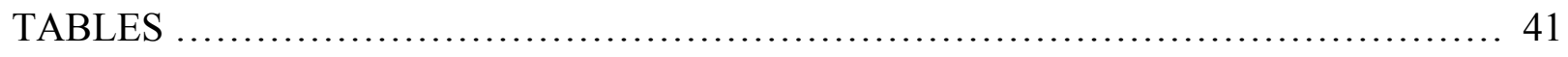

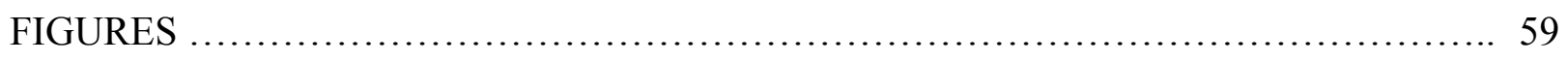

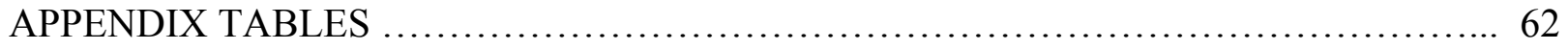




\section{LIST OF TABLES}

Table 1. Collection dates and distribution of 432 ruffed grouse collected among regions, sites,

sexes, and years.

Table 2. Aggregate mass (\%), occurrence (\%), and Importance Values of forage classes found in crop contents of ruffed grouse collected in Michigan, Wisconsin and Minnesota (Northern) and 8 study sites in the central and southern Appalachians, 2000-2002. 42

Table 3. Aggregate mass (\%), frequency of occurrence, and Importance Values (IV) of forage classes from crops of ruffed grouse collected in March and April, 2000-2002 in Michigan, Wisconsin, and Minnesota (Northern) and 8 study sites in the central and southern Appalachians ${ }^{\mathrm{b}}$.

Table 4. Mean Importance Values of forages from crops of ruffed grouse collected in March and April, 2000-2002 in Michigan, Wisconsin, and Minnesota (Northern) and 8 study sites in the central and southern Appalachians. Only forages with IV $>0.05$ in at least 1 year are presented. Abbreviations are $1 .=$ leaves, fl.=flowers, c. $=$ catkins, $b t .=$ buds and twigs,

fr. $=$ fruit.

Table 5. Carcass fat (\%) of ruffed grouse collected March-April 2000-2002 in Michigan, Wisconsin, and Minnesota (Northern) and at 8 sites in the central and southern Appalachians. 


\section{LIST OF TABLES (Continued)}

Table 6. Results of information-theoretic model selection to evaluate competing a-priori models predicting mean pre-breeding carcass fat $(\%)$ of ruffed grouse collected from 8 sites in the central and southern Appalachians, 2000-2002 using crop food category Importance Values $^{\mathrm{a}}$ and the control variable Sex $(n=48)$. Statistics presented are number of parameters $(K)$, Akaike's Information Criterion adjusted for small sample size $\left(\mathrm{AIC}_{c}\right)$,

$\operatorname{AIC}_{c}$ difference $\left(\Delta_{i}\right)$, and $\operatorname{AIC}_{c}$ weight $\left(\omega_{i}\right)$.

Table 7. Results of information-theoretic model selection to evaluate competing a-priori models predicting mean pre-breeding carcass fat (\%) of ruffed grouse collected from 8 sites in the central and southern Appalachians, 2000-2002 using control variables (Sex, Site, Forest type) and Mast Index values $(n=48)$. Statistics presented are number of parameters $(K)$, Akaike's Information Criterion adjusted for small sample size $\left(\mathrm{AIC}_{c}\right)$, $\operatorname{AIC}_{c}$ difference $\left(\Delta_{i}\right)$, and $\mathrm{AIC}_{c}$ weight $\left(\omega_{i}\right)$

Table 8. Results of information-theoretic model selection to evaluate competing a-priori models predicting pre-breeding carcass fat (\%) of ruffed grouse collected from 8 sites in the central and southern Appalachians, 2000-2002 using control variables (Sex, Site, Forest type) and the presence/absence of acorns or beechnuts in crop (Mast; $n=326)$. Statistics presented are number of parameters (K), Akaike's Information Criterion (AIC), AIC difference $\left(\Delta_{i}\right)$, and AIC weight $\left(\omega_{i}\right)$. 


\section{LIST OF TABLES (Continued)}

Table 9. Results of information-theoretic model selection to evaluate competing a-priori models predicting pre-breeding reproductive organ mass for females (ovary mass + oviduct mass) and males (paired testes mass) ruffed grouse collected from 8 sites in the central and southern Appalachians, 2000-2002 using \% carcass fat, crop-free body mass (MASS), and control variables (Site, Year). Statistics presented are number of parameters $(K)$, Akaike’s Information Criterion adjusted for small sample size $\left(\mathrm{AIC}_{c}\right)$,

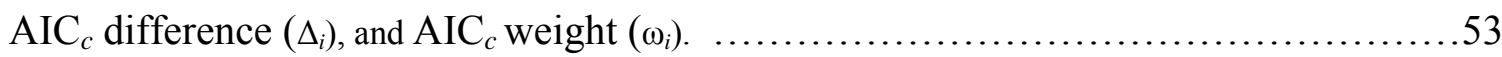

Table 10. Results of information-theoretic model selection to evaluate 8 a-priori models and 3 post-hoc models (models including fat class) predicting mean incubation date, clutch size, and hatching success of radio-transmittered ruffed grouse nests on 8 sites in the central and southern Appalachians, 2000-2002 using site, year, mean pre-breeding carcass fat (\%) and carcass fat class (low, moderate, high) of grouse collected from same sites $(n=22)$. Statistics presented are number of parameters $(K)$, Akaike's Information Criterion adjusted for small sample size $\left(\mathrm{AIC}_{c}\right), \mathrm{AIC}_{c}$ difference $\left(\Delta_{i}\right)$, and $\mathrm{AIC}_{c}$ weight $\left(\omega_{i}\right)$.

Table 11. Results of information-theoretic model selection to evaluate 8 a-priori models and 3 post-hoc models (models including fat class) predicting nest success and hen success of radio-transmittered ruffed grouse nests and females on 8 sites in the central and southern Appalachians, 2000-2002 using site, year, mean pre-breeding carcass fat (\%) and carcass fat class (low, moderate, high) of grouse collected from same sites $(n=22)$. Statistics presented are number of parameters $(K)$, Akaike's Information Criterion adjusted for small sample size $\left(\mathrm{AIC}_{c}\right), \mathrm{AIC}_{c}$ difference $\left(\Delta_{i}\right)$, and $\mathrm{AIC}_{c}$ weight $\left(\omega_{i}\right)$. 


\section{LIST OF TABLES (Continued)}

Table 12. Results of information-theoretic model selection to evaluate 8 a-priori models and 3 post-hoc models (models including fat class) predicting realized ${ }^{\mathrm{a}}$ chick survival and Recruitment Indices (number chicks alive at 5 weeks post-hatch per female alive on April 1) of radio-transmittered ruffed grouse on 8 sites in the central and southern Appalachians, 2000-2002 using site, year, mean pre-breeding carcass fat (\%) and carcass fat class (low, moderate, high) of grouse collected from same sites $(n=22)$. Statistics presented are number of parameters $(K)$, Akaike's Information Criterion adjusted for small sample size $\left(\mathrm{AIC}_{c}\right), \mathrm{AIC}_{c}$ difference $\left(\Delta_{i}\right)$, and $\mathrm{AIC}_{c}$ weight $\left(\omega_{i}\right) \ldots \ldots \ldots \ldots \ldots \ldots \ldots . \ldots \ldots$

Table 13. Results of information-theoretic model selection to evaluate 8 a-priori models and 3 post-hoc models (models including fat class) predicting potential ${ }^{\mathrm{a}}$ chick survival and Recruitment Indices (number chicks alive at 5 weeks post-hatch per female alive on April 1) of radio-transmittered ruffed grouse on 8 sites in the central and southern Appalachians, 2000-2002 using site, year, mean pre-breeding carcass fat (\%) and carcass fat class (low, moderate, high) of grouse collected from same sites $(n=22)$. Statistics presented are number of parameters $(K)$, Akaike's Information Criterion adjusted for small sample size $\left(\mathrm{AIC}_{c}\right), \mathrm{AIC}_{c}$ difference $\left(\Delta_{i}\right)$, and $\mathrm{AIC}_{c}$ weight $\left(\omega_{i}\right)$.

Table 14. Mean post-hatch reproductive parameters of central and southern Appalachian study sites by condition class of collected ruffed grouse, 2000-2002. Contrasts were used to test for differences between groups and numeric superscripts denote significant differences $(P$ $<0.05$ ) between the classes as follows: $1=$ low vs. high, $2=$ low vs. moderate and high combined. No differences were found between high vs. low and moderate combined. .58 


\section{LIST OF TABLES (Continued)}

Table A.1. Percent aggregate mass, frequency of occurrence, and Importance Values (IV) ${ }^{\mathrm{a}}$ of forages from crops of ruffed grouse collected in March and April, 2000-2002 in Michigan, Wisconsin, and Minnesota (Northern) and 8 study sites in the central and southern Appalachians. Only forages with IV $>0.05$ in at least 1 year are presented. Abbreviations are 1.=leaves, fl.=flowers, $\mathrm{c} .=$ catkins, bt. $=$ buds and twigs, fr. $=$ fruit. $\ldots \ldots .62$

Table A.2. Body composition (grams water, lipid, protein, and ash) of ruffed grouse collected in March - April, 2000-2002 in Michigan, Wisconsin and Minnesota (Northern) and 8 sites in the central and southern Appalachians. 71

Table A.3. Body composition (percent water, lipid, protein, and ash) of ruffed grouse collected in March - April, 2000-2002 in Michigan, Wisconsin and Minnesota (Northern) and 8 sites in the central and southern Appalachians. 


\section{LIST OF FIGURES}

Figure 1. Locations of Appalachian Cooperative Grouse Research Project study sites used in this research in 2000-2002. Square markers identify study sites having oak-hickory forests; circles identify study sites having mixed-mesophytic forests. Study site abbreviations and collection dates are: PA = Pennsylvania (28 March - 3 April); MD = Maryland (23 March - 29 March); WV1 = West Virginia 1 (21 March - 27 March); WV2 = West Virginia 2 (19 March - 25 March); VA1 = Virginia 1 (21 March - 27 March); VA3 = Virginia 3 (25 March - 19 March); KY = Kentucky (13 March - 9 March); NC = North Carolina (13 March - 19 March).

Figure 2. Relation between the Mast Index (sum of the rankings of red/black oak, white oak, chestnut oak, and beech production as none [0], light [1], moderate [2], or heavy [3]) and mean pre-breeding carcass fat (\%) of female ruffed grouse on 8 sites in the central and southern Appalachians, 2000-2002 $(n=24)$.

Figure 3. Relation between the Mast Index (sum of the rankings of red/black oak, white oak, chestnut oak, and beech production as none [0], light [1], moderate [2], or heavy [3]) and mean pre-breeding carcass fat (\%) of male ruffed grouse on 8 sites in the central and southern Appalachians, 2000-2002 $(n=24)$. 


\section{INTRODUCTION}

Ruffed grouse (Bonasa umbellus) are an important game bird whose range includes much of Canada, the northern United States, and the central and southern Appalachian mountains (Aldrich 1963). Grouse densities are lower in the central and southern Appalachians (Weber and Barick 1963, Stoll and Culbertson 1995) than in northern portions of their range (Bump et al. 1947, Rusch and Keith 1971a, Fischer and Keith 1974). Moreover, biologists are concerned by hunter surveys that suggest possible population declines in the Appalachians (Gwynn 1980, Wright 1995).

An inadequate winter diet has been hypothesized to negatively influence pre-breeding condition of females and possibly contribute to low grouse densities in the central and southern Appalachians (Servello and Kirkpatrick 1987, 1988). Leaves of evergreen plants, fruits, and ferns comprise the majority of the winter diet of grouse in the southern Appalachians (Gilfillan and Bezdek 1944, Stafford and Dimmick 1979, Seehorn et al. 1981, Servello and Kirkpatrick 1987, Barber et al. 1989a), whereas grouse in the northern United States and Canada forage primarily on buds, twigs, and catkins of aspen (Populus spp.) and, to a lesser extent, other northern hardwood tree species (Bump et al. 1947, Rusch and Keith 1971b, Svoboda and Gullion 1972, Doerr et al. 1974, Jakubas and Gullion 1991). Where available, soft and hard mast are used extensively during fall and winter months in the southern Appalachians, but substantial annual and regional variations in mast production may limit its ability to sustain grouse through winter (Servello and Kirkpatrick 1987). Many evergreen forages consumed in winter by grouse in the southern Appalachians have low energy and protein levels (Treichler et al.1946, Billingsley and Arner 1970, Servello and Kirkpatrick 1987, Guglielmo and Karasov 1995) and contain toxic secondary compounds that may inhibit digestion (Servello and Kirkpatrick 1987, 
Hewitt and Kirkpatrick 1997a). Poor quality diets can lead to reduced egg production, hatching success, and chick survival in captive ruffed grouse (Beckerton and Middleton 1982), northern bobwhite (Colinus virginianus; Giuliano et al. 1996), wild turkey (Meleagris gallapavo; Porter et al. 1983) and poultry (Harms and Waldroup 1963, Begin and Insko 1972, Butts and Cunningham 1972, Gardner and Young 1972, Menge et al. 1979), but effects of diet on condition and reproductive success have not been examined in wild ruffed grouse.

Age ratios of grouse in the Appalachians suggest lower recruitment (Davis and Stoll 1973, Norman et al. 1988) compared to the northern range (Dorney 1963, Rusch and Keith 1971a), which may be the result of lower nest success and/or higher chick mortality. Research conducted by the Appalachian Cooperative Grouse Research Project (ACGRP) indicates lower chick survival in the central and southern Appalachians than in other regions (Norman et al. 2004). Proximate causes of high chick mortality, such as exposure and predation, may ultimately be the result of poor female condition due to a low-quality diet and high energetic demands in late-winter and early spring.

Pre-breeding nutritional ecology of ruffed grouse is poorly understood. Ruffed grouse feeding habits are primarily limited to examination of hunter-killed birds, which only provides dietary information during fall and winter periods (Svoboda and Gullion 1972, Stafford and Dimmick 1979, Seehorn et al. 1981, Servello and Kirkpatrick 1987, Jakubas and Gullion 1991). Limited data regarding late-winter and early-spring diets are available from Ohio (Stoll et al. 1980) and New York (Woehr and Chambers 1975), but were obtained using fecal analysis methods, which may have inherent bias due to differential digestion of foods (Korschgen 1967). Two studies conducted in southwestern Virginia examined crop contents and assessed body condition during the breeding season. Norman and Kirkpatrick (1984) reported mean percent 
carcass fat from 3 females collected in March as 4.8\%. Servello and Kirkpatrick (1988) found substantially higher mean fat levels $(13.8-22.4 \%)$ in female grouse $(n=39)$ collected during March and April over a 3-year period, suggesting annual differences in diet quality and body condition. No studies to date have compared pre-breeding body condition from different regions or examined the effects of female nutrition and condition on productivity or recruitment.

A thorough knowledge of the factors limiting ruffed grouse in the central and southern Appalachians is important to the development of management guidelines for the region. The ACGRP was initiated in 1996 to examine ruffed grouse ecology and population dynamics in the central and southern Appalachians. Working in cooperation with the ACGRP, I investigated regional variation in pre-breeding nutrition and condition that may influence ruffed grouse productivity and population dynamics in the southern portion of the range. The primary objectives of my research were to: (1) document regional and annual differences in pre-breeding food habits and condition of ruffed grouse, (2) examine the relations between pre-breeding diet and condition of ruffed grouse, and (3) investigate the effect of pre-breeding condition on reproductive success of ruffed grouse in the central and southern Appalachians.

\section{STUDY AREAS}

Grouse were collected for food habits and condition data on 8 ACGRP study areas in the central and southern Appalachians (Fig. 1) and throughout Michigan, Wisconsin, and Minnesota (hereafter referred to as "Northern"). Reproductive and mast availability data were obtained only on ACGRP sites. Forest cover was classified as oak-hickory on the Kentucky (KY), Virginia-1 (VA1), and West Virginia-2 (WV2) study areas and mixed mesophytic on the Maryland (MD), North Carolina (NC), Pennsylvania (PA), Virginia-3 (VA3), and West Virginia- 
1 (WV1) sites (Braun 1950, Norman et al. 2004). Important tree species associated with oakhickory sites included white oak (Quercus alba), red oak (Q. rubra), chestnut oak (Q. prinus), black oak (Q. velutina) scarlet oak (Q. coccinea), pignut hickory (Carya glabra), mockernut hickory (C. tomentosa), bitternut hickory (C. cordiformis), shagbark hickory (C. ovata), red maple (Acer rubrum), sugar maple (A. saccharum), American beech (Fagus grandifolia), Virginia pine (Pinus virginiana), pitch pine (P. rigida), Table Mountain pine (P. pungens), white pine (P. strobes) and eastern hemlock (Tsuga canadensis). Mountain laurel (Kalmia latifolia) and great rhododendron (Rhododendron maximum) thickets were common understory components (Braun 1950). Tree species on study sites with a mixed mesophytic association included black cherry (Prunus serotina), sweet birch (Betula lenta), yellow birch (B. alleghaniensis), American beech, sugar maple, basswood (Tilia americana), northern red oak, yellow-poplar (Liriodendron tulipifera), white pine, and eastern hemlock (Braun 1950). Norman et al. (2004) provides more detailed site descriptions including vegetative survey data for ACGRP sites. Ruffed grouse were collected statewide in northern states. Efforts were made to collect grouse in aspen or aspen-conifer forest types that are typical of grouse habitat in the region (Barber et al. 1989b).

\section{METHODS}

\section{Grouse Collections}

Ruffed grouse were collected by shooting beginning 9 weeks prior to the mean hatching date for each site as determined by preliminary ACGRP data or published literature and ending after 1 week on ACGRP sites and 2 weeks in northern states (Table 1). In the Appalachians, 
grouse were collected from similar habitats located within a $30-\mathrm{km}$ radius of each ACGRP study site.

Each specimen was externally sexed (Servello and Kirkpatrick 1986, Kalla and Dimmick $1995)$ and frozen in 2 plastic freezer bags (i.e., double bagged). After partial thawing ( $<24$ hours in refrigerator) and mass determination, all feathers were plucked, the head was at the base of the skull, and the legs were removed at the tibio-tarsus-tarsometatarsus junction to facilitate homogenization. Crop and esophageal contents (hereafter referred to as crop contents) were removed and weighed and then re-froze them for later analysis. Crop-free mass was determined by subtraction. Digestive and reproductive tracts were removed. Fat adhering to the crop, gizzard, and intestines was stripped and placed back into the body cavity. After blotting surface moisture with a paper towel, ovaries, oviducts, and paired testes were weighed to determine the extent of gonadal recrudescence. The remainder of the carcass was sectioned into 3-5-cm pieces, refroze, and ground in a commercial meat grinder.

\section{Carcass Composition}

Ground carcasses were weighed, placed in aluminum pans, lyophilized for approximately 96 hours, and reweighed to determine initial percent moisture. The dried sample was then homogenized in a 1-L commercial blender (Waring ${ }_{\circledast}$ Commercial, Torrington, Connecticut), randomly subsampled, and placed in airtight bags. West Virginia University Division of Animal and Veterinary Sciences personnel performed all proximate analyses (Association of Official Analytical Chemists 1990). Moisture remaining after lyophilization (residual moisture) was determined for duplicate, 2-g homogenate subsamples by oven-drying at $110^{\circ} \mathrm{C}$ for 12 hours. Ether-extractable lipids of 2, 1.5-g subsamples were extracted for 18-24 hours using petroleumether in a Soxhlet apparatus. Percent protein $(6.25 \times \mathrm{N})$ was calculated for 20.75 -g samples 
using the Kjeldahl procedure (Association of Official Analytical Chemists 1990). Two, 3-g homogenate samples were combusted for 12 hours in a $550^{\circ} \mathrm{C}$ muffle furnace to determine percent ash. Percentages were averaged for the duplicate measures of each analysis. Residual and initial moisture percentages were summed to determine total percent moisture of the sample. Proportions of lipid, protein, and ash were multiplied by dry carcass mass to obtain dry mass of respective carcass components.

\section{Pre-Breeding Food Habits}

Individual crop contents were thawed and separated food items into 11 forage classes based on structural and nutritional differences: (1) herbaceous leaves and flowers; (2) evergreen leaves; (3) deciduous leaves; (4) ferns; (5) buds and twigs; (6) oak and beech fruits; (7) other hard fruits; (8) soft fruits; (9) catkins; (10) aspen flower buds; and (11) animal matter. Grit was excluded from all analyses because it was only found in trace amounts and has little nutritional value. The evergreen leaf class consisted largely of broad-leaved shrubs and vines that commonly hold leaves year-round including mountain laurel, greenbrier (Smilax spp.), and trailing arbutus (Epegaea repens). Due to the timing of collections, most of the deciduous leaf class was comprised of leaves recently emerging from swelled buds. Buds that were swelled, but not broken, were placed in the bud and twig class. Hard fruits were defined as forages from which the primary nutritional value is obtained from the seed (e.g., maple [Acer spp.] samaras and witch-hazel [Hamamelis virginiana] seeds). Soft fruits were classified as forages in which the pericarp surrounding the seed provides the most nourishment (e.g., grape [Vitis spp.], greenbrier, and sumac [Rhus spp.]). This classification is similar to Servello and Kirkpatrick (1987), with the exception of 2 additional categories. Oak and American beech fruits and aspen flower buds were separated from other classes due to their apparent high nutritional value 
(Servello and Kirkpatrick 1987) and use during the pre-breeding period. Specific foods that were commonly found in crops were identified and the proportion of the food category that was comprised of the forage was visually estimated.

Separated crop contents were placed in paper envelopes, labeled, and air-dried for a minimum of 7 days. Air-dried contents were desiccated in a $50^{\circ} \mathrm{C}$ convection oven until they reached a constant mass ( $>24$ hours) to determine dry mass of each forage class. I modified the aggregate volume method (AM) of calculating food habits data by substituting mass for volume (Martin et al. 1946). This method expresses percentages of forages as a percent of the total aggregate mass crop contents from a given study area and year. I developed an Importance Value (IV = [aggregate mass (\%) calculated using AM method / $100+$ occurrence (\%) / 100] / 2) to assess the relative importance of forage classes and individual foods on a scale of 0 to 1 . Because AM is biased when a few individuals consume inordinate amounts of a rare forage (Swanson et al. 1974), percent occurrence (proportion of grouse from a given site and year with food class in crop) was incorporated into the IV. Therefore, the 2 components of the equation buffer each other and minimize potential biases.

Mast production was assessed for each study site by visually estimating production of common mast producing species between August and December. Observers ranked the production of white oak, chestnut oak, red/black oak, and American beech as none (0), light (1), moderate (2), or heavy (3). The Mast Index was computed as the sum of the ranks of red/black oak, white oak, chestnut oak, and beech (possible range of 0-12).

\section{Reproductive Success}

Reproductive data were gathered only at ACGRP study sites. Grouse were captured in fall or late winter in clover-leaf traps (Liscinsky and Bailey 1955, Gullion 1965), sexed, aged 
(Servello and Kirkpatrick 1986, Kalla and Dimmick 1995), leg-banded, and fitted with a 10-g necklace-style radio transmitter equipped with an 8-hour mortality switch (Advanced Telemetry Systems, Inc., Isanti, Minnesota, USA). Transmitters were attached with an 8.3-cm nylon overbraid steel cable encased in shrink tubing. Grouse were released at the capture site immediately after processing. Radio-telemetry was used to monitor daily movements during the reproductive season (April-June). If a transmittered female was found at the same location for several consecutive days, incubation was assumed and the nest was visually located and flagged. If telemetry results suggested nest abandonment, predation, or hatching, researchers revisited the nest-site to determine its status. Females that were unsuccessful in first nest attempts were monitored for renest attempts. Within \pm 1 day of 21 and 35 days post-hatch, successful females were visually located and chicks counted. A recount was conducted if observers believed the first count was incomplete. If the number of chicks counted was lower than the number hatched or the previous count, chicks were assumed dead. If the number of chicks counted was higher than previous counts, underestimation on the prior check was assumed and data were adjusted.

Nesting rate, mean clutch size, mean incubation initiation date, hatching success, and nest success was calculated annually for each site using data from first nesting attempts only. Nesting rate, proportion of females that attempted to nest, was 1.0 on nearly all sites and years and therefore was excluded from analyses. Hatching success was calculated as the proportion of eggs from all nests that hatched. Nest success was calculated as the proportion of nests from which 1 or more chicks hatched. Female success, the proportion of females with at least 1 successful nest, was determined for the entire nesting season. Data relative to renest attempts were limited and therefore were not included in these analyses. Realized chick survival at brood counts was estimated as the number of chicks counted/number of eggs hatched in each brood. 
Because female condition may be unrelated to mortality of the adult female and subsequent entire brood loss, potential chick survival was also calculated by censoring broods of females that were killed prior to brood counts. Realized Recruitment Index was the number of chicks alive at 5-weeks post hatch per female alive on April 1, whereas the potential Recruitment Index was the number of chicks alive at 5-weeks post hatch per female that survived through the nesting and brood-rearing period. Additional detail regarding ACGRP reproductive data collection procedures and parameter calculation is found in Devers (2004).

\section{Data Analyses}

Prior to analyses, all data were screened for normality using the Shapiro-Wilk statistic and homogeneity of variances using Levene's test. The variable percent carcass fat was logtransformed for all bird-level analyses, but untransformed means and standard errors are reported. Continuous variables were tested for pair-wise correlation; all comparisons showed $r<$ 0.5 and therefore no variables were removed. SAS software was used for all analyses (SAS Institute, 1996, Cary, North Carolina). Small sample sizes precluded analysis for each state in Michigan, Wisconsin, and Minnesota and those data were subsequently pooled and termed "Northern." A General linear model (PROC GLM) was used to identify differences in condition between regions and gender with year as a covariate.

Diet-Condition Relations.-To investigate the relation between pre-breeding diet and condition of ruffed grouse in the Appalachians, I used an information-theoretic approach (Burnham and Anderson 1998) and conducted 3 separate model selection exercises. First, I used general linear models (PROC GLM) to assess the ability of 29 a-priori models to predict carcass fat levels. I summarized food habits data and used food class importance values as the explanatory variables related to mean percent carcass fat for each site/sex/year combination. 
Models were developed to explain possible relations based on known nutritional values of forages and previous research. I incorporated various combinations of the following variables into the series of models: HERB (herbaceous leaves and flowers IV), OAKBEECH (oak and beech fruits IV), EVERGREEN (evergreen leaves IV), FERN (ferns IV), BUD (buds and twigs IV), SOFTMAST (soft mast IV), HARDMAST (hard mast except oak and beech IV), and CATKIN (catkins IV). Because animal matter, aspen flower buds, and deciduous leaves were found rarely in samples, their respective food categories were excluded from the analysis. I expected large differences between sexes based on previous studies (Norman and Kirkpatrick 1984, Servello and Kirkpatrick 1988). Therefore, I included sex as a control variable in 14 models.

In this and all subsequent information-theoretic analyses, I evaluated the fit of each global model (i.e., most highly parameterized model) using $R^{2}$ values (Eberhardt 2003). If the global model provided an adequate fit I continued with the model selection process; if the global model did not provide an adequate fit, the model selection process was ended. Model selection was based on Akaike's Information Criterion (AIC), AIC differences $\left(\Delta_{\mathrm{i}}\right)$, and Akaike weights $\left(\omega_{i}\right)\left(\right.$ Burnham and Anderson 1998). AIC adjusted for small sample size $\left(\mathrm{AIC}_{\mathrm{c}}\right)$ was used when $n / K<40$ (Burnham and Anderson 2002). Akaike weight estimates the probability that a particular model is the best model in the candidate set. Models within $2 \mathrm{AIC}$ or $\mathrm{AIC}_{\mathrm{c}}$ units were considered the "best" competing models. Beta coefficients were examined for all continuous parameters in competing models and were positive unless reported.

Secondly, I specifically examined the effect of oak and beechnut production and consumption on the condition of pre-breeding ruffed grouse in the central and southern Appalachians. I developed 13 a-priori models using combinations of control variables [Sex, 
Site, and Forest Type (either oak-hickory or mixed mesophytic; Braun 1950)] and Mast Index to investigate the relation between mast availability and mean percent carcass fat at the site level. Because differences between sites were not of interest in this study and sites were treated simply as sampling locations within the Appalachian region, the variable site was modeled as a random coefficient, not a fixed variable, in all analyses (Longford 1993). As a result inferences obtained via the analyses presented here are applicable beyond the boundaries of the individual study areas. An information-theoretic approach was used to assess models as previously described. However, PROC MIXED was used to handle random and fixed effects simultaneously. These tests determined the effects of mast production at the site-level, but I suspected that mast variation within sites might be masking the relation between mast and condition at the bird-level. Although nutritional information regarding individual birds was limited to crop contents, I hypothesized that the presence or absence of acorns or beechnuts in the crop at the time of collection may be adequate to suggest that grouse had access to hard mast throughout the winter period to such a level as to increase the nutritional fitness of that bird. Therefore, I conducted a third modeling exercise using the same models and variables as the preceding test except that MASTCROP was used instead of the Mast Index and was categorized as 0 (acorns or beechnuts absent from crop) and 1 (acorns or beechnuts present in crop).

Condition-Reproduction Relations.- To better understand the potential effects of prebreeding ruffed grouse condition on reproduction in the central and southern Appalachians, I conducted a series of information model selection exercises. I tested the hypothesis that carcass fat levels influence the extent of reproductive organ development using 15 a-priori models. The same set of models was used with 2 data sets, one using female reproductive organ mass (sum of ovary and oviduct mass) as the response variable and the second using male paired-testes mass 
as the dependent variable. The primary explanatory variable of interest was percent carcass fat, but I also included MASS (crop-free dry mass) in some models to account for differences in body size. Site and year were included as control variables in some models to account for variation due to unknown factors related to each location or annual weather differences that may affect reproductive chronology.

A second series of models was assessed to investigate the effects of female condition on reproductive success. I developed 8 a-priori models to explain variation in mean incubation date, mean clutch size, nesting success, hatching success, realized chick survival to 3 weeks posthatch, potential chick survival to 3 weeks post-hatch, realized chick survival to 5 weeks posthatch, potential chick survival to 5 weeks post-hatch, realized Recruitment Index, and potential Recruitment Index. The main explanatory variable of interest was mean percent carcass fat of female grouse for each site/year combination, but I also included Site and Year as control variables in some models. I also examined models containing only control variables. Following initial analysis and data inspection, I developed 3 a-posteriori models. I divided the site/year carcass fat means into 3 classes (low, moderate, or high) and then used this new variable, Fat Class, as an explanatory variable. Because these post-hoc analyses were not planned and were added to reveal an apparent trend, inferences gathered from the results should be viewed with caution. If a model including Fat Class was considered competing, contrasts (PROC GLM, CONTRAST option) were used to compare means between condition classes: low vs. high, low vs. moderate and high combined, and high vs. low and moderate combined. Only site/year combinations with a complete suite of data (all parameters obtained from the sample of females/broods) were included. Data from North Carolina and Kentucky in 2002 were excluded due to several missing reproduction data. 


\section{RESULTS}

Over the 3-year period, 432 ruffed grouse were collected, including 352 from the 8 ACGRP sites in the central and southern Appalachians and 80 from Michigan, Wisconsin, and Minnesota (Table 1). Thirty-one crops (7\%) did not contain foods and were eliminated from food habits analyses. Heads were destroyed by shooting on 2 specimens and were subsequently excluded from analyses involving crop-free mass, but were included in the remainder of analyses. Collections also resulted in damaged testes $(n=20)$, ovaries $(n=9)$, and oviducts $(n=$ 8) and these data were discarded from respective analyses.

\section{Pre-breeding Food Habits}

Regional Comparisons. - Pre-breeding diets of grouse inhabiting oak-hickory and mixed-mesophytic forests in the Appalachians differed qualitatively from diets of northern grouse found primarily in aspen or aspen-conifer forests (Table 2). Aspen flower buds made up $46 \%$ of crop contents in northern samples but $<1 \%$ in samples from the Appalachians. Bud and twig and catkin consumption was slightly higher in northern states than in samples from the Appalachians. Herbaceous leaves and flowers were eaten regularly in both regions, occurring in $80 \%$ of northern crops and $91 \%$ of Appalachian crops, despite making up only $24 \%$ and $25 \%$ of the aggregate dry mass, respectively. Evergreen leaves, ferns, oak and beech fruits, and soft fruits were important forages in the Appalachians (IVs > 0.17) but rarely occurred in northern crops (IVs < 0.02). Animal matter, primarily "fireflies" (Photinus spp.), was found in $24 \%$ of northern crops but only comprised $0.6 \%$ of the total crop contents.

Pennsylvania.- Among ACGRP sites, aspen flower buds occurred only in crops from Pennsylvania in 2000 and made up 16\% of contents (Table 3). Herbaceous leaves and flowers occurred in most crops in all years and comprised between $12 \%$ and $56 \%$ of crop contents with 
cinquefoil (Potentilla spp.) and avens (Guem spp.) leaves and coltsfoot (Tussilago farfara) flowers as the most common forages in the class (Table 4; See Table A.1 for annual food habits data for each forage). The bud and twig forage class, largely comprised of serviceberry (Amelachier spp.), black birch, and cherry was important in 2000 and 2001 (IVs > 0.40), but comprised only $2 \%$ of crop contents in 2002 . Catkin use was moderate during $2000(\mathrm{IV}=0.27)$, but was nearly absent in 2001 and 2002. Hard and soft mast species comprised $>20 \%$ of crop contents in all years, primarily consisting of sumac and greenbrier fruits in 2000 and maple and beech fruits in 2001. Acorns were heavily used by 6 of 13 grouse collected in 2002 and accounted for $78 \%$ of total crop mass.

Maryland.- Grouse in Maryland used herbaceous leaves and flowers extensively in all years (IVs > 0.68; Table 3). Cinquefoil, birdsfoot-trefoil (Lotus corniculatus), and avens leaves and coltsfoot flowers were important individual herbaceous forages (Table 4). Evergreen and deciduous leaf classes were found in few crops, but fern use was moderate (IVs $>0.25$ ). Buds and twigs were present in 6 of 9 crops in 2001, comprising $11 \%$ of contents, but were absent in 2002 when $31 \%$ of the crop contents were made up of acorns. Other hard mast fruits were rarely consumed with the exception of 2001 when maple samaras comprised $50 \%$ of crop contents (IV $=0.14)$ and cherry fruits $(\mathrm{IV}=0.14)$ were the most common fruits eaten.

West Virginia.- Herbaceous leaves and flowers occurred in $>77 \%$ of crops from WV1 and WV2, but accounted for a much smaller percentage of the aggregate mass in both sites and years (13-45\%; Table 3). Evergreen leaves, primarily mountain laurel and dewberry (Rubus hispidus), comprised 18\% and 55\% of crop contents from WV1 in 2000 and 2001, respectively. Greenbrier fruits made up 20\% of crop contents from WV1 in 2000, and hard and soft mast fruit classes comprised $18 \%$ of contents in 2001. Acorns were consumed by 5 of 13 grouse from 
WV2 in 2000 and accounted for $65 \%$ of crop contents, but were only moderately important forages in 2001 and 2002 (IV $=0.11$ and 0.27 , respectively). Only 1 crop from WV2 contained acorns in 2001, whereas witch-hazel, maple, greenbrier and grape fruits were used extensively. Evergreen leaves were present in 11 of 14 crops from WV2 in 2002 and made up $38 \%$ of total crop mass.

Virginia. - In 2000, acorns made up a large portion of the diet at VA1 (61\%) and VA3 (24\%), despite being consumed by relatively few individuals ( 5 of 16 and 3 of 21, respectively; Table A.1). Greenbrier berries and coltsfoot flowers also contributed substantially to crop contents in 2000. Herbaceous leaves and flowers (IV >0.64), evergreen leaves (IV >0.31), and ferns (IV > 0.11) were relatively abundant in 2001 at both sites and in 2002 at VA1 (Table 3). Soft fruits, mainly Viburnum spp., made up 20\% of contents in VA1 in 2001, whereas buds and twigs were more important at VA3. Acorns dominated the diet of grouse at VA3 in 2002, with 11 of 13 grouse consuming oak mast totaling $90 \%$ of crop contents.

Kentucky.-Although food habits data from Kentucky in 2000 and 2001 was limited to only 9 crops, it appeared that grouse primarily consumed herbaceous leaves and flowers in 2000 (100\% aggregate mass) and beechnuts in 2001 (97\% aggregate mass; Table 3). A larger sample from 2002 showed that recently emerging multiflora rose (Rosa multiflora) leaves were consumed in large quantities by certain grouse (32\% of total contents), but herbaceous leaves and flowers and ferns were more consistently eaten.

North Carolina. - In North Carolina, mountain laurel leaves comprised a large percentage (29\%) of crop contents in 2000, but only 3\% in 2001 when soft fruits made up 35\% of contents. Herbaceous leaf use was higher in 2000 and 2002 than 2001 (IV = 0.74, 0.74, and 0.54 , respectively), whereas bud and twigs were more important in 2001 (IV $=0.40)$. 
Additionally, catkins were absent from crops in 2000 and 2002, but accounted for $12 \%$ of

contents in 2001. Ferns were the second most frequently consumed forage class in 2002, with an IV of 0.38 .

\section{Pre-breeding Nutritional Condition}

Body Composition.- Individual grouse carcass fat levels ranged from $1.3 \%$ to $39.7 \%$

with a mean of $9.9 \%(\mathrm{SE}=0.34)$. Mean percent carcass fat varied substantially both among and within sites and years and between sexes (Table 5). Female grouse consistently contained greater percent carcass fat $($ mean $=12.5 \%, \mathrm{SE}=0.57)$ than did males $($ mean $=7.4 \%, \mathrm{SE}=0.30$; $\left.F_{1,429}=72.25, P<0.001\right)$. Grouse collected in northern states had lower fat levels (mean $=$ $6.0 \%, \mathrm{SE}=0.39)$ than grouse collected in the Appalachians $\left(\right.$ mean $=10.8 \%, \mathrm{SE}=0.39 ; F_{1,429}=$ $52.35, P<0.001)$. Mean weights and proportions of moisture, protein, and ash are reported in Tables A.2 and A.3, respectively. However, these metrics were generally inversely related to percent carcass fat and much less variable, which limited their usefulness in assessing condition. Percent carcass fat is generally considered the most accurate and precise metric to assess avian body condition (Johnson et al. 1985). Therefore, I focused my investigations of pre-breeding condition on factors relating to and effects of percent carcass fat of collected grouse.

Diet-Condition Relations. - I found a strong relation between pre-breeding diet, as estimated by forage class importance values, and condition of ruffed grouse on a site-level in the Appalachians. The "best" model selected $\left(\omega_{\mathrm{i}}=0.48\right.$; Table 6$)$ suggested that, while accounting for sex differences, evergreen leaf consumption was negatively related, and oak and beech fruit and fern consumption was positively related to mean percent carcass fat $(\mathrm{Y}=2.29-0.389$ [Sex] $-0.006[$ EVERGREEN $]+0.006[$ FERN $]+0.010[\mathrm{OAKBEECH}]+\varepsilon) . \quad$ A $2^{\text {nd }} \operatorname{model}\left(\omega_{\mathrm{i}}=0.41\right)$ was a competing "best" model and also suggested bud and twig IV was negatively related and 
catkin IV was positively related to fat levels $(\mathrm{Y}=2.36-0.367$ [Sex] -0.003 [EVERGREEN] + $0.006[\mathrm{FERN}]-0.005[\mathrm{BUD}]+0.009[\mathrm{OAKBEECH}]+0.006[\mathrm{CATKIN}]+\varepsilon)$.

Mast availability as estimated by Mast Index was related to mean percent carcass fat (Table 7; Figs. 2 and 3). Model selection procedures yielded 2 competing models $\left(\omega_{i}=0.32\right.$ and 0.37; Table 7). Both models included 2 variables, sex and Mast Index. However the best model also included site, which was modeled as a random variable.

Acorn and beechnut consumption was related to percent carcass fat at the individual birdlevel. The "best" model included sex, site, and Mast (presence or absence of oak or beech mast in crop) and was found to be the only reasonable model to explain variation in percent carcass fat at the bird level $\left(\omega_{i}=1.00\right.$; Table 8$)$. Although differences between sites were evident, the presence or absence of mast in the crop was an important determinant of condition. Females collected with mast in their crops contained $20 \%$ carcass fat $(n=34, \mathrm{SE}=1.6)$, whereas females collected without mast in their crops only had $11.7 \%$ carcass fat $(n=123, \mathrm{SE}=0.6)$. A similar difference was found in males where a mean of $12.9 \%$ carcass fat $(n=21, \mathrm{SE}=1.2)$ was observed when mast was present and $7.2 \%$ carcass fat $(n=148, \mathrm{SE}=0.3)$ was found when mast was absent.

Condition-Reproduction Relations. - I found evidence suggesting pre-breeding condition was related to the extent of ovarian development. The single "best" model selected included site, year, and $\%$ carcass fat $\left(\omega_{\mathrm{i}}=0.80\right.$; Table 9$)$. Condition also appeared to influence testes size. However, model selection uncertainty was evident and 4 models were classified as competing (Table 9). The 2 "best" models included percent carcass fat, whereas the other 2 models only included year or year and site effects. 
Several relations were found between pre-breeding female condition and estimates of reproductive output at the site-level. The most parsimonious model explaining variation in mean incubation included year and fat class $\left(\omega_{i}=0.84\right.$; Table 10$)$. Multiple models with a variety of parameters were classified as competing to best explain mean clutch size of ruffed grouse nests. However, the model including year and fat class was considered the "best" model. Hatching success was influenced most strongly by site $\left(\omega_{i}=0.81\right.$; Table 10$)$. The random effect of site was also the only parameter included in the best model describing nest success and female success $\left(\omega_{i}=0.82\right.$ and 0.58 , respectively; Table 11$)$.

Variation in realized chick survival to 3 weeks post-hatch was best explained by 2 models with identical $\mathrm{AIC}_{c}$ values (Table 12). The models including fat class only and site and fat class were selected as the only plausible models $\left(\omega_{i}=0.45\right)$. The same 2 models were competing in explaining realized chick survival to 5 weeks post-hatch. However the model with only fat class was selected as the "best" model $\left(\omega_{i}=0.66\right.$; Table 12). Realized recruitment indices were best explained by the model including the terms year and fat class $\left(\omega_{i}=0.91\right.$; Table 12). The same models were selected to explain variation in potential post-hatch reproductive parameters (Table 13). Models including site and fat class and only fat class were competing in describing potential 3 and 5 week post-hatch chick survival and the model including only year and fat class was the most parsimonious model to describe recruitment index.

Subsequent data analyses using contrasts revealed large differences in chick survival and recruitment rates between sites with low mean fat levels and sites with moderate and high fat levels combined. Sites with low mean fat levels had significantly lower realized and potential chick survival rates at 3 and 5 weeks post-hatch than sites with moderate and high fat levels $\left(F_{1,22}>10.6, P<0.006\right.$; Table 14). Sites with moderate or high fat levels also showed 
significantly higher realized and potential Recruitment Index values than sites with low fat levels $\left(F_{1,22}>12.9, P<0.004\right)$.

\section{DISCUSSION}

\section{Pre-breeding Food Habits}

In the central portion of the ruffed grouse range and in New England, high consumption of aspen flower buds in fall, winter, and early spring has been well documented (Darrow 1939, Bump et al 1947, Stollberg et al. 1952, Svoboda and Gullion 1972, Doerr et al 1974, Woehr and Chambers 1975). I found aspen buds comprised $38-44 \%$ of northern crop contents and occurred in 25 of 75 crops analyzed. Moreover, I often found crops nearly filled to capacity with aspen buds. Reports of foraging sessions for grouse feeding in aspen trees average 16-24 minutes (Svoboda and Gullion 1972, Doerr et al 1974). When aspen is available, it is likely that grouse ignore other foods and consume aspen buds until satiated. However, it is clear that many northern grouse do not have access to or do not select aspen flower buds in late-March to early April. Doerr et al. (1972) found few grouse feeding on aspen after the first week of April in Alberta, and related the cessation to lack of snow cover. Grouse in Michigan, Wisconsin, and Minnesota were collected in late-March to mid-April when snow cover varied among collection sites and years. I speculate that the relatively low proportion of grouse crops containing aspen was probably related to the timing of collections and the transition from eating exclusively aspen to a mixed diet in the absence of widespread snow cover. Grouse were collected throughout the northern states and it is likely that the lack of snow and warming temperatures enabled grouse in some areas to forage on herbaceous vegetation more easily. 
Food habits data from central and southern Appalachians also qualitatively suggested that collections occurred during a time of transition. Large dietary differences among and within sites and years were evident. The variety of foods recorded, including hard and soft mast, evergreen leaves, ferns, buds, twigs, and catkins, was similar to previously reported winter food habits data from the southeast portion of the range (Stafford and Dimmick 1979, Seehorn et al 1981, Norman and Kirkpatrick 1984, Servello and Kirkpatrick 1987) and from spring-collected crops in Virginia (Servello and Kirkpatrick 1988). Grouse in this study were found to forage on herbaceous vegetation to a greater extent than previous studies using hunter-killed specimens but less than grouse collected in spring and summer in Virginia (Norman and Kirkpatrick 1984, Servello and Kirkpatrick 1988). Herbaceous leaves or flowers occurred in over 90\% of crops from the Appalachians, suggesting that recently-emerging vegetation is an important nutritional resource that is highly sought during spring green-up. Protein requirements of gallinaceous birds during egg-laying are estimated to be $175 \%$ greater than during winter (Robbins 1981). Herbaceous leaves are the most protein-rich forage class available to egg-laying grouse, containing $21-29 \%$ protein (Servello and Kirkpatrick 1987). Therefore, the high use of green forages was expected during the pre-laying period. However, annual variation in herbaceous food use was evident. For example, in Pennsylvania, herbaceous leaves made up 56\% of crop contents in 2001, but they were relatively unimportant in 2000 when aspen flower buds, buds and twigs, and soft fruits were the most frequently recorded forages. Although collections occurred during the same week each year, spring green-up was functionally later in 2000 , which may have limited the availability of "green" forages. Recently emerging leaves and flowers of species such as cinquefoil, strawberry, and coltsfoot are a readily available source of protein for 
females and probably contribute greatly to the dietary needs of grouse in the weeks immediately preceding egg laying.

Perhaps more enlightening are the inferences that can be drawn from the non-herbaceous portion of the food habits data. It is likely that few, if any, grouse had access to abundant herbaceous forage in the weeks and months prior to collections. Most forbs and flowers found in crops were among the earliest species to germinate in spring, such as cinquefoil and coltsfoot, and were in their early stages of development. Servello and Kirkpatrick (1987) documented that herbaceous plants made up less than $20 \%$ of the diet during January and February in southeastern states with the majority of the diet consisting of fruits, and the leaves, buds, and twigs of woody species. Evergreen leaves, primarily mountain laurel, greenbrier, dewberry, wintergreen, and trailing arbutus are among the poorest quality forages (Servello and Kirkpatrick 1987) but were consumed regularly in the Appalachians, occurring in 36\% of crops and accounting for $12 \%$ of crop contents in this study. Mountain laurel consumption was inversely related to hard mast use on most sites. For example, at WV2 in 2000 , evergreen leaves comprised only $4 \%$ of crop contents when acorns were abundant (65\% aggregate mass), but in 2002 acorns made up 5\% of contents and evergreen leaves were consumed by nearly every grouse and accounted for $34 \%$ of crop contents. Local mast failures may force some grouse in the Appalachians to consume substantial quantities of evergreen forages, possibly affecting the physiological condition of females in late-winter.

Acorns and beechnuts were an important component of the pre-breeding diet of grouse in the Appalachians, consistent with previous food habits reports from the region in winter (Norman and Kirkpatrick 1984, Servello and Kirkpatrick 1987) and spring (Servello and Kirkpatrick 1988). The persistence of these forages through March and early April on some sites 
was somewhat surprising though. Acorns and beechnuts made up a large portion of the aggregate diet in the Appalachians while being found in only a small percentage of crops, suggesting acorns and beechnuts are consumed in large quantities when found. Masting patterns of oaks are highly variable (Koenig and Knops 2002) and this variability was strikingly evident in crop analysis. Oak fruits were nearly absent from crop contents at PA and VA3 in 2000 and 2001 , but made up $78 \%$ and $90 \%$ of crop contents in 2002 , respectively. On the WV2 site, acorns comprised $65 \%$ of contents in 2000 , and then decreased to $12 \%$ in 2001 , and $5 \%$ in 2002 . Beechnuts, though only found to be important in Kentucky, showed similar patterns of variability, accounting for $97 \%$ of crop contents in 1 year while absent the other 2 years. Servello and Kirkpatrick (1988) noted a similar "boom or bust" pattern to acorn use during March and April. Acorns and beechnuts are among the most energy-rich forages available for grouse (Servello and Kirkpatrick 1987, Servello and Kirkpatrick 1989) and appear to be highly selected when available.

Soft fruits, an important food source in summer, fall, and early winter (Stafford and Dimmick 1979, Seehorn et al 1981, Norman and Kirkpatrick 1984, Servello and Kirkpatrick 1987) expectedly were eaten less in early spring. Most soft fruits were probably eaten or had decayed prior to the collection period, and fruits of greenbrier, grape, and sumac were the only fruits found in substantial quantities. Bud and twig use varied but occurred in nearly $50 \%$ of all crops collected in the Appalachians. Consistent with previous accounts (Stafford and Dimmick 1979, Seehorn et al 1981, Norman and Kirkpatrick 1984, Servello and Kirkpatrick 1987), birch, cherry, serviceberry, blueberry, and huckleberry were among the most common species of buds eaten. Buds and twigs are a low-energy, high-fiber food source that is readily available when other more nutritious species are absent. 


\section{Pre-breeding Nutritional Condition}

Grouse collected in Michigan, Wisconsin, and Minnesota had an average of $44 \%$ less carcass fat than grouse collected in the central and southern Appalachians. Similarly, Thomas et al. (1975) found low fat reserves in grouse in Ontario collected from January-August ranging from 5.9-9.3\%. I found mean carcass fat levels in grouse collected in the Appalachians to be highly variable, ranging from $5.6-27.0 \%$ for females and $4.1-19.0 \%$ for males, depending on year and location. Values within that range have been reported for grouse collected in Virginia in December and January (Norman and Kirkpatrick 1984), and March (Servello and Kirkpatrick 1988). Norman and Kirkpatrick (1984) noted a significant decrease in fat levels between December and April and Thomas et al. (1975) documented an approximately 30\% drop in fat levels between April and May, suggesting grouse may rapidly deplete carcass fat during the egglaying period. Most collections of grouse in the Appalachians in this study occurred approximately 2 weeks prior to egg laying during mid-late March. Thus, the range of values I reported likely reflects a near-maximum level of body reserves available to females for egg production. Females accumulated greater fat reserves than males in this study, consistent with previous accounts of ruffed grouse condition in Virginia (Norman and Kirkpatrick 1984, Servello and Kirkpatrick 1988). Servello and Kirkpatrick (1988) suggested that lower spring fat levels in males was due to an increase of time spent near drumming locations and defending territories that may limit time spent foraging.

As expected, a strong relation was evident between the pre-breeding diet and condition of grouse in the Appalachians. I found condition was influenced more by acorn and beechnut consumption than other forages. The correlation between hard mast and condition was more strongly detected at the bird-level. The presence or absence of acorns or beechnuts in the crop at 
time of collection was a powerful predictor of fat levels. Females collected with oak or beech mast in their crops averaged $71 \%$ more carcass fat than those not consuming hard mast. The effect of hard mast on male condition was even greater. Previous researchers have reported anecdotal evidence that high acorn intake may contribute to increased fat reserves (Servello and Kirkpatrick 1988). Acorns are a highly digestible source of energy (Servello and Kirkpatrick 1989) and when abundant likely satisfy the dietary needs of grouse with minimal foraging times, which may also decrease exposure to predators.

The Mast Index was also related to carcass fat levels at the site level after accounting for gender differences (Table 7, Figures 2 and 3). Whitaker (2003) found poor mast crops contributed to increased home range size on ACGRP sites with oak-hickory forest types but not in mixed mesophytic types, suggesting nutritional constraints were acting on sites with limited alternate forages. I found no interaction between forest type and mast availability on prebreeding fat levels. However, the Mast Index-condition relation appeared to be stronger on some sites than others. I believe large within-site variation in forest cover, mast production, and body condition masked this relation on some sites when site means were used as the experimental unit. Nevertheless, my findings support the hypothesis that hard mast production is an important factor influencing ruffed grouse pre-breeding condition on a landscape scale.

Expectedly, I found that bud and twig and evergreen leaf consumption were negatively related to pre-breeding condition. Buds, twigs, and leaves of evergreen woody plants are lowenergy foods often consumed during winter and early spring. These findings support the conclusions of previous researchers that evergreen forages, particularly mountain laurel, are among the poorest-quality foods available to grouse in the Appalachians (Hewitt and Kirkpatrick 1997, Servello and Kirkpatrick 1987). Hewitt and Kirkpatrick (1997) found that grouse could 
maintain body mass with diets containing $<20 \%$ evergreen leaves, but grouse consuming $>40 \%$ evergreen matter were unable to maintain body mass. Although evergreen leaves did not comprise $>40 \%$ of the composite diet at any site, the diets of individual grouse are largely unknown because individual crop contents only represent what the grouse consumed on the day of collection. However, I found 30 of 326 crops from the Appalachians contained $>40 \%$ evergreen leaves and 13 crops contained $>75 \%$ evergreen leaves. If these grouse did not have access to higher quality foods during late-winter, excess consumption of toxic phenols present in evergreen leaves may be affecting nearly $10 \%$ of the grouse in the region. Additionally, forbs and flowers were undoubtedly much less available in the weeks preceding collections and prior to spring green-up. If alternate foods such as mast were absent, evergreen leaf consumption may have been substantially higher during that critical late-winter period.

An unexpected finding was the positive relation between fern consumption and prebreeding condition found in the series of crop food categories with the greatest influence on condition. Servello and Kirkpatrick (1987) found Christmas fern (Polystichum acrostichoides) to be among the least energy-rich forages available. However, fern is often a major understory component of mature oak forests, and its occurrence may be related to habitat use by grouse searching for high-energy acorns. Although the variables OAKBEECHIV and FERNIV used in my analyses were not significantly correlated $\left(r^{2}=0.25\right)$, it is reasonable to suggest that many grouse with access to acorns in the weeks preceding collections consumed ferns as "filler" while searching for patchily distributed acorns.

\section{Effects of Nutrition and Condition on Reproduction}

Although the influence of diet on pre-breeding condition of grouse in the Appalachians was evident, the effect of condition on productivity and population ecology is more difficult to 
assess. Few studies have attempted to quantify the relation between condition and reproduction in gallinaceous birds, limiting direct comparisons with other studies. Until recently no method of accurately determining condition on a living specimen was available and most condition research, including the present study, relied on collections and subsequent proximate analysis for condition data. Once sacrificed, reproductive data cannot be obtained and therefore direct effects of condition on reproductive output at the bird-level have been impossible to assess. I made the assumption that a randomly collected sample of females from each study site was representative of the pre-breeding conditional state of transmittered females that were used to estimate reproductive output for that site. The validity of my assumption is unknown. However, I believe any relations revealed at this coarse level of examination are likely to be much stronger if the same sample of grouse could be used for all measurements. Large within-site variations in food habits, condition, and reproductive output were evident and undoubtedly influenced my ability to detect relations. Despite these methodology shortcomings, I found evidence that poor prebreeding condition may decrease reproductive output at the site level via delayed incubation and reduced clutch size and chick survival.

Delayed incubation due to nutritional stress and dietary deficiencies has been noted in ruffed grouse (Beckerton and Middleton 1982), ring-necked pheasants (Phasianus colchicus; Gates and Whoeler 1968), and poultry (Harms and Waldroup 1963) in experimental situations, and this study supports previous findings. Although year was also included in the best model, females on sites with higher mean fat levels tended to nest earlier than on sites with lower mean fat levels. Delayed nesting could affect chick survival and potential for renesting attempts. Although the data supported several models, clutch size appeared to be positively related to fat levels, particularly after accounting for site and year effects. Low dietary energy decreased egg 
production in captive northern bobwhite by 41-58\% (Guiliano et al. 1996), but no such relation has been reported in ruffed grouse. Dietary energy influences hatchability in turkeys (Menge et al. 1979) and Coturnix quail (Coturnix japonica; Begin and Insko 1972) and similar effects are plausible in ruffed grouse. However, my data do not support such a relation. I also found nesting success and female success to be influenced only by site. This is understandable given that most nesting failures in this study were due to depredation (Smith et al. 2003, Devers 2004). However, I hypothesized that incubating females with lower fat reserves may spend more time foraging to maintain condition, thereby increasing the risk of nest exposure to predators. It also may be reasonable to purport that females in poorer condition may simply inhabit marginal habitats that are lacking in both nutritional resources and adequate nesting cover. Although these complex relations may be evident with more rigorous examination, the effect of site-specific variables such as predator densities and habitat quality appeared to be more influential than condition on nesting success and female success in this study.

Although I found weak evidence linking pre-breeding condition to some pre-hatching reproductive parameters, this study revealed an even more convincing relation between condition and chick survival. Fat levels accounted for $43 \%$ and $47 \%$ of variation in realized and potential chick survival to 3-weeks post-hatch, respectively. Weather has long been hypothesized to be a primary factor affecting early chick survival in ruffed grouse (Bump et al. 1947, Dorney and Kabat 1960). I did not measure any weather variables and assumed that any weather effects would be manifested in site or year effects. Although some site and year effects were found, female condition appeared to have a relatively greater influence on early chick survival. Realized chick survival on sites with low mean fat levels was $61 \%$ and $45 \%$ lower than sites with moderate and high mean fat levels, respectively. Previous studies provide conflicting results 
regarding possible maternal effects on avian offspring fitness. Although I did not measure any aspect of egg quality in this study, the most probable intermediate mechanism causing this apparent relation would be increased egg size or yolk size. Yolk content increases in response to increased dietary energy and protein levels in other gallinaceous birds (Gardner and Young 1972, Menge et al. 1979, Begin and Insko 1972). Williams (1994) noted that $47 \%$ of studies examining egg size and offspring survival revealed a positive relation in precocial birds, though he stressed that data are stronger regarding effects of egg size on early chick survival. Extensive research on red grouse (Lagopus l. scoticus) in Scotland provides conflicting hypotheses on maternal effects on chick survival (Jenkins et al 1967, Moss 1969), but this aspect of nutritional ecology has not yet been examined in ruffed grouse.

Effects of poor pre-breeding female condition did not appear to be compensated for as the brood matured and fewer chicks were recruited at 5 weeks of age on sites with poor pre-breeding condition. Survival to 5 -weeks post hatch on sites with low mean fat levels was $65 \%$ and $50 \%$ lower than sites with moderate and high mean fat levels, respectively. Contrary to my expectations, this relation was not linear. My data suggested that survival and recruitment may be highest when grouse are in a moderate state of nutritional condition (11-15\% carcass fat), and that productivity may actually decline when grouse retain large amounts of body fat. Grouse with abnormally large fat reserves may have been feeding exclusively on high-energy, lowprotein food sources such as acorns. Large amounts of both energy and protein are needed for reproduction and it is possible that protein deficiencies may account for lowered reproductive output. However, I suggest there is simply a threshold level of fat reserves that is needed for successful reproduction, and once this threshold is exceeded other factors become more influential than condition. On the basis of my findings, in areas where females have less than 
$11 \%$ body fat, recruitment tends to decrease substantially, largely driven by poor chick survival. Conversely, recruitment is likely adequate in areas inhabited by grouse with average or aboveaverage fat reserves and chick survival is probably more dependent on weather, predation, and/or brood habitat constraints.

\section{CONCLUSIONS}

My results suggest: (1) pre-breeding condition in ruffed grouse in the central and southern Appalachians is largely influenced by diet, (2) hard mast plays a key role in increasing fat reserves in grouse, but when mast is unavailable grouse are forced to consume poorer quality forages including buds and twigs and evergreen leaves, (3) poor condition may negatively impact reproductive success via delayed nesting, reduced clutch size and particularly lowered chick survival, and (4) grouse in the central portion of their range have substantially less fat reserves than grouse in the central and southern Appalachians, suggesting large differences in the nutritional ecology between regions.

Exactly why grouse populations in the central and southern Appalachians occur at lower densities than more northern populations is still largely unknown. However, this study suggests the nutritional ecology of grouse inhabiting the 2 regions is different. In the northern range, grouse feed on a relatively constant supply of forages throughout the fall, winter, and early spring. Foods such as buds and catkins of aspen are of moderate nutritional value, but are abundant and widely distributed throughout the core of the grouse's range. Although grouse in the northern region may not accumulate large fat reserves, there is probably no need to; at anytime they can move a short distance to meet their dietary and reproductive nutritional needs. However, grouse in the Appalachians depend on foods that are much more variable in quality 
and less predictable in availability. Hard mast, which appears to be the most selected forage of grouse in the central and southern Appalachians, exhibits substantial spatial and temporal variation. Grouse may have to travel long distances to find these sometimes patchily distributed mast-producing trees and forage in habitats where they are presumably more exposed to predators. My data shows that only about $20 \%$ of grouse may have access to hard mast in latewinter. Without mast, grouse must rely on low-energy foods including evergreen leaves, ferns, and buds and twigs. Grouse consuming these forages have lower fat reserves that may not be adequate to maintain the level of nutritional condition required for reproductive demands.

Although most of the analyses presented here were relative to the landscape level, anecdotal evidence suggests complex relations among nutrition, condition, and reproduction are most likely occurring at the bird-level. Large variation in food habits and condition was strikingly evident within certain study areas that contained multiple habitat types. For example in Pennsylvania, grouse that were collected from one side of the study site where habitat was diverse and generally considered ideal had high fat levels, whereas grouse collected on the other side of the area where oak and mountain laurel were dominant habitat components had extremely poor body condition in 2 of 3 years. These nutrition and condition differences are probably occurring at a home-range level (macrohabitat) and therefore the effects of nutritional deficiencies are difficult to detect at the site or landscape level. Grouse productivity in the Appalachians may be influenced by the percentage of female grouse within a given area that have adequate nutrition (i.e., at or above the threshold level). The distribution and composition of habitat types is probably a key factor in determining the proportion of grouse that are adequately prepared for successful nesting and brood-rearing. Areas with a diversity of habitat types that can supply high-quality foods even in the absence of unpredictable hard mast crops 
may produce the highest numbers of grouse. In oak-dominated areas, grouse populations may be at the mercy of annual oak production, increasing following years of abundant mast, and decreasing in years when it is less available. This may be the reason that grouse in the Appalachians do not exhibit "cycles" like northern grouse, but rather exhibit stochastic patterns from year to year.

Although this field research provides strong evidence regarding the importance of nutrition and female condition in Appalachian forests, additional research in this area is needed. A well-designed experiment to assess the effect of varying realistic diet regimens on female condition and productivity, in the absence of confounding environmental factors, would provide a worthy test of this hypothesis. Additionally, data on food availability in the Appalachians during the winter and early spring are clearly lacking, but if obtained may provide additional support for the hypothesis of nutritional constraint. Lastly, if oak mast is as important as this and other studies suggest, a thorough investigation of how regional and local variation in oak abundance affects grouse population levels may provide a powerful explanation of why grouse populations vary over time and lead to enhanced understanding of population regulation in oakdominated ecosystems.

\section{MANAGEMENT IMPLICATIONS}

This and other studies suggest that grouse in the Appalachians are nutritionally stressed at certain times throughout the year (Norman and Kirkpatrick 1984, Servello and Kirkpatrick 1987, Hewitt and Kirkpatrick 1997a, Whitaker 2003). Grouse in more northern regions are not thought to be food-limited, but most current management regimes have been modeled from ones developed for those regions. Because the nutritional ecology of grouse inhabiting the 
Appalachians differs dramatically from northern grouse, habitat management prescriptions should not be applied universally among regions. Extensive clear-cutting of northern forests yields maximum stem densities and adequate food supplies necessary to support grouse populations, but similar silvicultural practices used in Appalachian oak-hickory forests may decrease mast production and produce monocultures of poor-quality forages. Whitaker (2003) provides detailed recommendations regarding habitat management designed to increase food production in the Appalachians. Although timber harvests are clearly the most beneficial and efficient option to increase grouse habitat in the region, potential food resources should be assessed prior to any action. Forest stand diversity should be the goal of habitat management in the Appalachians, providing the high stem density that is needed for cover while encouraging hard and soft mast production and abundant herbaceous cover through well-planned timber harvests. 


\section{LITERATURE CITED}

Aldrich, J. W. 1963. Geographic orientation of American Tetraonidae. Journal of Wildlife Management 27:529-545.

Association of Official Analytical Chemists. 1990. Official methods of analysis. $15^{\text {th }}$ ed. Association of Official Analytical Chemists, Washington, D. C., USA

Barber, H. L., F. J. Brenner, R. Kirkpatrick, F. A. Servello, D. F. Stauffer, and F. R. Thompson. 1989a. Food. Pages 268-282 in Atwater, S., and J. Schnell, editors. The wildlife series: ruffed grouse. Stackpole Books, Harrisburg, Pennsylvania, USA.

Barber, H. L., R. Kirkpatrick, J. Kubisiak, D. Rusch, F. A. Servello, S. K. Staforrd, D. F. Stauffer, and F. R. Thompson III. 1989b. The ecological niche. Pages 15-20 in Atwater, S., and J. Schnell, editors. The wildlife series: ruffed grouse. Stackpole Books, Harrisburg, Pennsylvania, USA.

Beckerton, P. R., and A. L. A. Middleton. 1982. Effects of dietary protein levels on ruffed grouse reproduction. Journal of Wildlife Management 46:569-579.

Begin, J. J., and W. M. Insko, Jr. 1972. The effects of dietary protein level on the reproductive performance of Coturnix breeder hens. Poultry Science 51:1662-1669.

Billingsley, B. B., and D. H. Arner. 1970. The nutritive value and digestibility of some winter foods of the eastern wild turkey. Journal of Wildlife Management 34:176-182.

Braun, E. L. 1950. Deciduous forests of eastern North America. Blakiston Company, Philadelphia, PA. 
Bump, G., R. W. Darrow, F. C. Edminster, and W. F. Crissey. 1947. The ruffed grouse: life history, propagation, management. New York State Conservation Department, Albany, New York, USA.

Burnham, K. P., and D. R. Anderson. 1998. Model Selection and inference: a practical information-theoretical approach. Springer, New York. 353 pp.

Butts, J. N., and F. E. Cunningham. 1972. Effect of dietary protein on selected properties of the egg. Poultry Science 51:1726-1734.

Darrow, R. 1939. Seasonal food preferences of adult and young grouse in New York State. Transactions of the North American Wildlife Conference 4:585-590.

Davis, J. A., and R. J. Stoll. 1973. Ruffed grouse age and sex ratios in Ohio. Journal of Wildlife Management 37:133-141.

Devers, P. K. 2004. Population ecology and the effects of hunting on ruffed grouse (Bonasa umbellus) in the southern and central Appalachians. Ph.D. Dissertation. Virginia Polytechnic Institute and State University, Blacksburg, Virginia. 195 pp.

Doerr, P. D., L. B. Keith, D. H. Rusch, and C. A. Fischer. 1974. Characteristics of winter feeding aggregations of ruffed grouse in Alberta. Journal of Wildlife Management 38:601615.

Dorney, R. S. 1963. Sex and age structure of Wisconsin ruffed grouse populations. Journal of Wildlife Management 27:599-603. , and C. Kabat. 1960. Relation of weather, parasitic disease and hunting to Wisconsin ruffed grouse populations. Wisconsin Conservation Department Technical Bulletin 20. Eberhardt, L. L. 2003. What should we do about hypothesis testing? Journal of Wildlife Management 67:241-247. 
Fischer, C. A., and L. B. Keith. 1974. Population responses of central Alberta ruffed grouse to hunting. Journal of Wildlife Management 38:585-600.

Gardner, F. A., and L. L. Young. 1972. The influence of dietary protein and energy levels on the protein and lipid content of the hen's egg. Poultry Science 51:994-997.

Gilfillan, M. C., and H. Bezdek. 1944. Winter foods of the ruffed grouse in Ohio. Journal of Wildlife Management 8:208-210.

Giuliano, W. M., R. S. Lutz, and R. Patino. 1996. Reproductive responses of adult female northern bobwhite and scaled quail to nutritional stress. Journal of Wildlife Management 60:302-309.

Guglielmo, C. G., and W. H. Karasov. 1995. Nutritional quality of winter browse for ruffed grouse. Journal of Wildlife Management 59:427-436.

Gullion, G. W. 1965. Improvements in methods for trapping and marking ruffed grouse. Journal of Wildlife Management 29:109-116. , and W. H. Marshall. 1968. Survival of ruffed grouse in a boreal forest. Living Bird $7: 117-167$.

Gwynn, J. V. 1980. Game questionnaire surveys. Pages 154-171 in Virginia Game Investigations. Virginia Commission of Game and Inland Fisheries, Richmond, Virginia, USA.

Harms, R. H., and P. W. Waldroup. 1963. Length of laying cycle as influenced by dietary protein level. Poultry Science 42:1195-1197.

Hewitt, D. G., and R. L. Kirkpatrick. 1996. Forage intake rates of ruffed grouse and potential effects on grouse density. Canadian Journal of Zoology 74:2016-2024. 
, and . 1997a. Ruffed grouse consumption and detoxification of evergreen leaves.

Journal of Wildlife Management 61:129-139. , and . 1997b. Daily activity times of ruffed grouse in southwestern Virginia.

Journal of Field Ornithology 68:413-420. , F. A. Servello, and . 1992. Ruffed grouse food availability in southwestern

Virginia. Proceedings of the Annual Conference of the Southeast Association of Fish and Wildlife Agencies 46:207-214.

Hill, D. C., E. V. Evans, and H. G. Lumsden. 1968. Metabolizable energy of aspen flower buds for captive ruffed grouse. Journal of Wildlife Management 32:854-858.

Jakubas, W. J., and G. W. Gullion. 1991. Use of quaking aspen flower buds by ruffed grouse: its relationship to grouse densities and bud chemical composition. Condor 93:473-485.

Jenkins, D., A. Watson, and G. R. Miller. 1967. Population fluctuations in the red grouse Lagopus lagopus scoticus. Journal of Animal Ecology 36:97-122.

Johnson, D. H, G. L. Krapu, K. J. Reinecke, and D. G. Jorde. 1985. An evaluation of condition indices for birds. Journal of Wildlife Management 49:569-575.

Kalla, P. I., and R. W. Dimmick. 1995. Reliability of established aging and sexing methods in ruffed grouse. Proceedings of the Annual Conference of the Southeast Association of Fish and Wildlife Agencies 49:580-593.

Koenig, W. D., and J. M. H. Knops. 2002. The behavioral ecology of masting in oaks. Pp 129148 in W. J. McShea and W. M. Healy, Eds. Oak forest ecosystems: ecology and management for wildlife, Johns Hopkins University Press, Baltimore, MD.

Korschgen, L. J. 1967. Feeding habits and food. Pages 137-198 in O. H. Hewitt, ed., The wild turkey and its management, The Wildlife Society, Washington, D. C. 
Liscinsky, S. A, and W. J. Bailey. 1955. A modified shorebird trap for capturing woodcock and grouse. Journal of Wildlife Management 19:405-408.

Longford, N. T. 1993. Random coefficient models. Oxford University Press, New York, NY.

Martin, A. C., R. H. Gensch, and C. P. Brown. 1946. Alternative methods in upland gamebird food analysis. Journal of Wildlife Management 10:8-12.

Menge, H., T. Frobish, B. T. Weinland, and E. G. Geis. 1979. Effect of dietary protein and energy on reproductive performance of turkey hens. Poultry Science 58:419-426.

Moss, R. 1969. A comparison of red grouse (Lagopus l. scoticus) stocks with the production and nutritive value of heather (Caluna vulgaris). Journal of Animal Ecology 38:103112.

Norman, G. W., and R. L. Kirkpatrick. 1984. Foods, nutrition, and condition of ruffed grouse in southwestern Virginia. Journal of Wildlife Management 48:183-187.

, N. W. Lafon, D. E. Steffen, and J. C. Jeffreys. 1988. 1997-98 Ruffed grouse population status in Virginia. Wildlife Resource Bulletin Number 98-7, Virginia Department of Game and Inland Fisheries, Richmond, Virginia, USA.

, D. F. Stauffer, J. Sole, T. J. Allen, W. K. Igo, S. Bittner, J. Edwards, R. L. Kirkpatrick, W. M. Giuliano, B. Tefft, C. Harper, D. Buehler, D. Figert, M. Seamster, and D. Swanson. 2004. Ruffed grouse ecology and management in the Appalachian region: Final project report of the Appalachian Cooperative Grouse Research Project.

Porter, W. F., G. C. Nelson, and K. Mattson. 1983. Effects of winter conditions on reproduction in a northern wild turkey population. Journal of Wildlife Management 47:281-290.

Robbins, C. T. 1981. Estimation of the relative cost of reproduction in birds. Condor 83:177179. 
Rusch, D. H., and L. B. Keith. 1971a. Seasonal and annual trends in numbers of Alberta ruffed grouse. Journal of Wildlife Management 35:803-822. , and _ _ 1971b. Ruffed grouse-vegetation relationships in central Alberta. Journal of Wildlife Management 35:417-429.

Seehorn, M. E., R. F. Harlow, and M. T. Mengak. 1981. Foods of ruffed grouse from three locations in the southern Appalachian mountains. Proceedings of the Annual Conference of the Southeast Association of Fish and Wildlife Agencies 35:216-224.

Servello, F. A. 1985. Regional variation in the nutritional ecology of ruffed grouse. Ph.D. Thesis, Virginia Polytechnic Institute and State University, Blacksburg, Virginia. 204pp. Servello, F. A., and R. L. Kirkpatrick. 1986. Sexing ruffed grouse in the Southeast using feather criteria. Wildlife Society Bulletin 14:280-282. , and _ _ 1987. Regional variation in the nutritional ecology of ruffed grouse. Journal of Wildlife Management 51:749-770. , and __ 1988. Nutrition and condition of ruffed grouse during the breeding season in southwestern Virginia. Condor 90:836-842. , and __ 1989. Nutritional value of acorns for ruffed grouse. Journal of Wildlife Management 53:26-29.

Smith, B. W., C. A. Dobony, J. W. Edwards, and W. Mark Ford. 2003. Observations of longtailed weasel, Mustela frenata, hunting behavior in central West Virginia. The Canadian Field-Naturalist 117:313-315.

Stafford, S. K., and R. W. Dimmick. 1979. Autumn and winter foods of ruffed grouse in the southern Appalachians. Journal of Wildlife Management 43:121-127. 
Stoll, R. J., M. W. McClain, C. M. Nixon, and D. M. Worley. 1980. Foods of ruffed grouse in Ohio. Ohio Fish and Wildlife Report 7. 17pp.

Stoll, R. J., and W. L. Culbertson. 1995. Ruffed grouse hunting pressure and harvest on an Ohio public hunting area. Fish and Wildlife Report 12. Ohio Department of Natural Resources, Division of Wildlife, Columbus, Ohio, USA.

Stollberg, B. P., R. L. Hine, J. B. Hale, Eds. 1952. Food habit studies of ruffed grouse, pheasant, quail and mink in Wisconsin. Wisconsin Department of Natural Resources Technical Bulletin 4. 22 pp.

Swanson, G. A., G. L. Krapu, J. C. Bartonek, J. R. Serie, and D. H. Johnson. 1974. Advantages in mathematically weighting food habits data. Journal of Wildlife Management 38:302-307.

Svoboda, F. J., and G. W. Gullion. 1972. Preferential use of aspen by ruffed grouse in northern Minnesota. Journal of Wildlife Management 36:1166-1180.

Thomas, V. G., H. G. Lumsden, and D. H. Price. 1975. Aspects of the winter metabolism of ruffed grouse (Bonasa umbellus) with special reference to energy reserves. Canadian Journal of Zoology 53:434-440.

Thompson, F. R. 1987. The ecology of the ruffed grouse in central Missouri. Dissertation. University of Missouri, Columbia, Missouri, USA.

Treichler, R., R. W. Stow, and A. L. Nelson. 1946. Nutrient content of some winter foods of ruffed grouse. Journal of Wildlife Management 10:12-17.

Weber, A. J., and Barick. 1963. Eleven years of ruffed grouse censusing in western North Carolina. Proceedings of the Annual Conference of the Southeast Association of Fish and Wildlife Agencies 17:13-15. 
Whitaker, D. M. 2003. Ruffed grouse (Bonasa umbellus) habitat ecology in the central and southern Appalachians. Ph.D. Dissertation. Virginia Polytechnic Institute and State University, Blacksburg, Virginia. 220pp.

Woehr, J. R., and R. E. Chambers. 1975. Winter and spring food preference of ruffed grouse in central New York. Transactions of the Northeast Section of the Wildlife Society 32:95-110.

Wright, B. A. 1995. Virginia survey of hunter harvest, effort, and attitudes, 1993-94. Virginia Game Department, Richmond, Virginia, USA. 
Table 1. Collection dates and distribution of 432 ruffed grouse collected among regions, sites, sexes, and years.

\begin{tabular}{|c|c|c|c|c|c|c|c|c|c|}
\hline \multirow{2}{*}{$\begin{array}{l}\text { Region } \\
\quad \text { State (Site) }\end{array}$} & \multicolumn{2}{|c|}{ Collection period } & \multicolumn{2}{|c|}{2000} & \multicolumn{2}{|c|}{2001} & \multicolumn{2}{|c|}{2002} & \multirow[b]{2}{*}{ Total } \\
\hline & Start date & End date & Female & Male & Female & Male & Female & Male & \\
\hline \multicolumn{10}{|l|}{ Appalachians } \\
\hline Kentucky (KY) & 13 Mar & $19 \mathrm{Mar}$ & 3 & 1 & 2 & 5 & 6 & 10 & 27 \\
\hline North Carolina (NC) & 13 Mar & 19 Mar & 8 & 12 & 9 & 11 & 7 & 10 & 57 \\
\hline Virginia (VA3) & 19 Mar & $25 \mathrm{Mar}$ & 12 & 10 & 6 & 8 & 8 & 5 & 49 \\
\hline West Virginia (WV2) & $19 \mathrm{Mar}$ & $25 \mathrm{Mar}$ & 5 & 8 & 7 & 4 & 6 & 9 & 39 \\
\hline Virginia (VA1) & $21 \mathrm{Mar}$ & $27 \mathrm{Mar}$ & 11 & 5 & 8 & 16 & 8 & 9 & 57 \\
\hline West Virginia (WV1) & $21 \mathrm{Mar}$ & 27 Mar & 6 & 8 & 6 & 2 & 10 & 7 & 39 \\
\hline Maryland (MD) & $23 \mathrm{Mar}$ & 29 Mar & 7 & 12 & 7 & 3 & 5 & 2 & 36 \\
\hline Pennsylvania (PA) & $28 \mathrm{Mar}$ & $3 \mathrm{Apr}$ & 8 & 11 & 7 & 8 & 8 & 6 & 48 \\
\hline Total & & & 60 & 67 & 52 & 57 & 58 & 58 & 352 \\
\hline \multicolumn{10}{|l|}{ Northern } \\
\hline Michigan & $1 \mathrm{Apr}$ & 14 Apr & 2 & 3 & 9 & 12 & 2 & 5 & 33 \\
\hline Wisconsin & $1 \mathrm{Apr}$ & 14 Apr & 6 & 7 & 4 & 6 & 0 & 1 & 24 \\
\hline Minnesota & 27 Mar & $9 \mathrm{Apr}$ & 8 & 6 & 2 & 0 & 3 & 4 & 23 \\
\hline Total & & & 16 & 16 & 15 & 18 & 5 & 10 & 80 \\
\hline Grand total & & & 76 & 83 & 67 & 75 & 63 & 68 & 432 \\
\hline
\end{tabular}


Table 2. Aggregate mass (\%), occurrence (\%), and Importance Values ${ }^{\mathrm{a}}$ of forage classes found in crop contents of ruffed grouse collected in Michigan, Wisconsin and Minnesota (Northern) and 8 study sites in the central and southern Appalachians, 2000-2002.

\begin{tabular}{|c|c|c|c|c|c|c|}
\hline \multirow[b]{2}{*}{ Forage class } & \multicolumn{3}{|c|}{ Northern $(n=75)$} & \multicolumn{3}{|c|}{ Appalachians $(n=326)$} \\
\hline & Mass & Occurrence & IV & Mass & Occurrence & IV \\
\hline Herbaceous leaves and flowers & 23.5 & 80.0 & 0.52 & 25.5 & 90.5 & 0.58 \\
\hline Evergreen leaves & 0.9 & 5.3 & 0.03 & 11.8 & 35.9 & 0.24 \\
\hline Deciduous leaves & 3.6 & 2.7 & 0.03 & 1.9 & 5.5 & 0.04 \\
\hline Ferns & 0.0 & 1.3 & 0.01 & 3.4 & 30.7 & 0.17 \\
\hline Buds and twigs & 18.6 & 42.7 & 0.31 & 12.2 & 47.2 & 0.30 \\
\hline Oak and beech fruits & 0.2 & 2.7 & 0.01 & 25.5 & 16.9 & 0.21 \\
\hline Other hard fruits & 0.2 & 2.7 & 0.01 & 4.5 & 9.5 & 0.07 \\
\hline Soft fruits & 2.0 & 1.3 & 0.02 & 10.8 & 18.1 & 0.14 \\
\hline Catkins & 4.1 & 10.7 & 0.07 & 3.8 & 7.7 & 0.06 \\
\hline Aspen flower buds & 46.4 & 33.3 & 0.40 & 0.5 & 2.1 & 0.01 \\
\hline Animal matter & 0.6 & 24.0 & 0.12 & 0.1 & 5.8 & 0.03 \\
\hline
\end{tabular}

${ }^{\mathrm{a}}$ Importance Value $(\mathrm{IV})=($ aggregate mass $(\%) / 100+$ occurrence $(\%) / 100) / 2$ 
Table 3. Aggregate mass (\%), frequency of occurrence, and Importance Values (IV) $)^{\mathrm{a}}$ of forage classes from crops of ruffed grouse collected in March and April, 2000-2002 in Michigan,

Wisconsin, and Minnesota (Northern) and 8 study sites in the central and southern Appalachians ${ }^{\mathrm{b}}$.

\begin{tabular}{|c|c|c|c|c|c|c|c|c|c|}
\hline \multirow{3}{*}{$\begin{array}{l}\text { Site }^{\mathrm{b}} \\
\quad \text { Forage class }\end{array}$} & \multicolumn{9}{|c|}{ Year } \\
\hline & \multicolumn{3}{|c|}{2000} & \multicolumn{3}{|c|}{2001} & \multicolumn{3}{|c|}{2002} \\
\hline & Mass & Freq & IV & Mass & Freq & IV & Mass & Freq & IV \\
\hline Northern $(n)$ & \multicolumn{3}{|c|}{$(32)$} & \multicolumn{3}{|c|}{$(31)$} & \multicolumn{3}{|c|}{$(12)$} \\
\hline Herbaceous leaves and flowers & 37.7 & 26 & 0.59 & 12.8 & 24 & 0.45 & 38.4 & 10 & 0.61 \\
\hline Evergreen leaves & 0.0 & 0 & 0.00 & 1.5 & 4 & 0.07 & 0.0 & 0 & 0.00 \\
\hline Deciduous leaves & 12.3 & 2 & 0.09 & 0.0 & 0 & 0.00 & 0.0 & 0 & 0.00 \\
\hline Ferns & $\operatorname{tr}$ & 1 & 0.02 & 0.0 & 0 & 0.00 & 0.0 & 0 & 0.00 \\
\hline Buds and twigs & 1.4 & 9 & 0.15 & 30.8 & 17 & 0.43 & 3.6 & 6 & 0.27 \\
\hline Oak and beech fruits & 0.0 & 0 & 0.00 & 0.0 & 0 & 0.00 & 1.2 & 2 & 0.09 \\
\hline Other hard fruits & 0.0 & 0 & 0.00 & 0.4 & 1 & 0.02 & 0.1 & 1 & 0.04 \\
\hline Soft fruits & 0.0 & 0 & 0.00 & 3.4 & 1 & 0.03 & 0.0 & 0 & 0.00 \\
\hline Catkins & 4.8 & 4 & 0.09 & 0.4 & 2 & 0.03 & 19.3 & 2 & 0.18 \\
\hline Aspen flower buds & 43.6 & 11 & 0.39 & 49.9 & 10 & 0.41 & 37.5 & 4 & 0.35 \\
\hline Animal matter & 0.1 & 3 & 0.05 & 0.9 & 15 & 0.25 & 0.0 & 0 & 0.00 \\
\hline $\mathrm{PA}(n)$ & \multicolumn{3}{|c|}{ (17) } & \multicolumn{3}{|c|}{ (13) } & \multicolumn{3}{|c|}{ (13) } \\
\hline Herbaceous leaves and flowers & 13.2 & 13 & 0.45 & 56.1 & 12 & 0.74 & 12.1 & 10 & 0.45 \\
\hline Evergreen leaves & 3.6 & 3 & 0.11 & 7.1 & 6 & 0.27 & 5.5 & 5 & 0.22 \\
\hline Deciduous leaves & 0.0 & 0 & 0.00 & 0.0 & 0 & 0.00 & 0.0 & 0 & 0.00 \\
\hline Ferns & 0.0 & 0 & 0.00 & 0.3 & 3 & 0.12 & 0.9 & 3 & 0.12 \\
\hline Buds and twigs & 27.5 & 9 & 0.40 & 12.0 & 11 & 0.48 & 2.3 & 8 & 0.32 \\
\hline Oak and beech fruits & 0.0 & 0 & 0.00 & 5.1 & 1 & 0.06 & 78.3 & 6 & 0.62 \\
\hline Other hard fruits & $\operatorname{tr}$ & 1 & 0.03 & 11.0 & 2 & 0.13 & $\operatorname{tr}$ & 1 & 0.04 \\
\hline Soft fruits & 20.1 & 5 & 0.25 & 8.4 & 5 & 0.23 & 0.5 & 2 & 0.08 \\
\hline Catkins & 19.3 & 6 & 0.27 & 0.0 & 0 & 0.00 & 0.3 & 1 & 0.04 \\
\hline Aspen flower buds & 16.2 & 7 & 0.29 & 0.0 & 0 & 0.00 & 0.0 & 0 & 0.00 \\
\hline Animal matter & 0.1 & 1 & 0.03 & $\operatorname{tr}$ & 1 & 0.04 & 0.1 & 3 & 0.12 \\
\hline
\end{tabular}


Table 3. Continued.

\begin{tabular}{|c|c|c|c|c|c|c|c|c|c|}
\hline \multirow{3}{*}{$\begin{array}{l}\text { Site } \\
\quad \text { Forage Class }\end{array}$} & \multicolumn{9}{|c|}{ Year } \\
\hline & \multicolumn{3}{|c|}{2000} & \multicolumn{3}{|c|}{2001} & \multicolumn{3}{|c|}{2002} \\
\hline & Mass & Freq & IV & Mass & Freq & IV & Mass & Freq & IV \\
\hline $\mathrm{MD}(n)$ & \multicolumn{3}{|c|}{ (18) } & \multicolumn{3}{|c|}{ (9) } & \multicolumn{3}{|c|}{$(5)$} \\
\hline Herbaceous leaves and flowers & 62.4 & 18 & 0.81 & 35.7 & 9 & 0.68 & 43.0 & 5 & 0.71 \\
\hline Evergreen leaves & 0.1 & 1 & 0.03 & 0.0 & 0 & 0.00 & 0.0 & 0 & 0.00 \\
\hline Deciduous leaves & 0.1 & 2 & 0.06 & 0.0 & 0 & 0.00 & 0.0 & 0 & 0.00 \\
\hline Ferns & 8.8 & 8 & 0.27 & 5.6 & 4 & 0.25 & 15.9 & 4 & 0.48 \\
\hline Buds and twigs & 5.4 & 4 & 0.14 & 11.1 & 6 & 0.39 & 0.0 & 0 & 0.00 \\
\hline Oak and beech fruits & 1.5 & 1 & 0.04 & 0.0 & 0 & 0.00 & 30.7 & 1 & 0.25 \\
\hline Other hard fruits & 4.4 & 2 & 0.08 & 28.6 & 4 & 0.37 & 0.0 & 0 & 0.00 \\
\hline Soft fruits & 2.6 & 2 & 0.07 & 18.0 & 2 & 0.20 & 9.9 & 1 & 0.15 \\
\hline Catkins & 14.4 & 1 & 0.10 & 0.0 & 0 & 0.00 & 0.0 & 0 & 0.00 \\
\hline Aspen flower buds & 0.0 & 0 & 0.00 & 0.0 & 0 & 0.00 & 0.0 & 0 & 0.00 \\
\hline Animal matter & 0.1 & 2 & 0.06 & 0.0 & 0 & 0.00 & 0.5 & 1 & 0.10 \\
\hline WV1 (n) & \multicolumn{3}{|c|}{ (14) } & \multicolumn{3}{|c|}{ (8) } & \multicolumn{3}{|c|}{ (15) } \\
\hline Herbaceous leaves and flowers & 15.7 & 12 & 0.51 & 20.1 & 8 & 0.60 & 42.5 & 14 & 0.68 \\
\hline Evergreen leaves & 17.5 & 4 & 0.23 & 54.7 & 5 & 0.59 & 4.1 & 2 & 0.09 \\
\hline Deciduous leaves & 8.1 & 3 & 0.15 & 0.0 & 0 & 0.00 & 4.3 & 1 & 0.05 \\
\hline Ferns & 0.1 & 2 & 0.07 & 4.4 & 5 & 0.33 & 2.6 & 2 & 0.08 \\
\hline Buds and twigs & 16.3 & 9 & 0.40 & 2.8 & 4 & 0.26 & 13.9 & 5 & 0.24 \\
\hline Oak and beech fruits & 0.0 & 0 & 0.00 & 2.8 & 2 & 0.14 & 15.1 & 1 & 0.11 \\
\hline Other hard fruits & 0.0 & 0 & 0.00 & 5.6 & 3 & 0.22 & 0.0 & 0 & 0.00 \\
\hline Soft fruits & 20.6 & 5 & 0.28 & 9.3 & 2 & 0.17 & 17.6 & 5 & 0.25 \\
\hline Catkins & 21.8 & 3 & 0.22 & 0.0 & 0 & 0.00 & 0.0 & 0 & 0.00 \\
\hline Aspen flower buds & 0.0 & 0 & 0.00 & 0.0 & 0 & 0.00 & 0.0 & 0 & 0.00 \\
\hline Animal matter & 0.0 & 0 & 0.00 & 0.0 & 0 & 0.00 & 0.0 & 0 & 0.00 \\
\hline $\mathrm{WV} 2(n)$ & \multicolumn{3}{|c|}{ (13) } & \multicolumn{3}{|c|}{ (10) } & \multicolumn{3}{|c|}{ (14) } \\
\hline Herbaceous leaves and flowers & 12.9 & 10 & 0.45 & 13.9 & 10 & 0.57 & 24.4 & 14 & 0.62 \\
\hline Evergreen leaves & 3.5 & 4 & 0.17 & 0.4 & 4 & 0.20 & 33.7 & 11 & 0.56 \\
\hline Deciduous leaves & 0.0 & 0 & 0.00 & 0.0 & 0 & 0.00 & 0.2 & 1 & 0.04 \\
\hline Ferns & 2.0 & 2 & 0.09 & 0.8 & 2 & 0.10 & $\operatorname{tr}$ & 1 & 0.04 \\
\hline Buds and twigs & 9.9 & 8 & 0.36 & 1.3 & 4 & 0.21 & 32.3 & 9 & 0.48 \\
\hline Oak and beech fruits & 65.0 & 5 & 0.52 & 11.8 & 1 & 0.11 & 5.2 & 4 & 0.17 \\
\hline Other hard fruits & 0.0 & 0 & 0.00 & 47.6 & 8 & 0.64 & 0.1 & 1 & 0.04 \\
\hline Soft fruits & 6.1 & 1 & 0.07 & 24.3 & 6 & 0.42 & 3.9 & 3 & 0.13 \\
\hline Catkins & 0.6 & 1 & 0.04 & 0.0 & 0 & 0.00 & $\operatorname{tr}$ & 1 & 0.04 \\
\hline Aspen flower buds & 0.0 & 0 & 0.00 & 0.0 & 0 & 0.00 & 0.0 & 0 & 0.00 \\
\hline Animal matter & 0.0 & 0 & 0.00 & 0.2 & 1 & 0.05 & 0.2 & 2 & 0.07 \\
\hline
\end{tabular}


Table 3. Continued.

\begin{tabular}{|c|c|c|c|c|c|c|c|c|c|}
\hline \multirow{3}{*}{$\begin{array}{l}\text { Site } \\
\quad \text { Forage Class }\end{array}$} & \multicolumn{9}{|c|}{ Year } \\
\hline & \multicolumn{3}{|c|}{2000} & \multicolumn{3}{|c|}{2001} & \multicolumn{3}{|c|}{2002} \\
\hline & Mass & Freq & IV & Mass & Freq & IV & Mass & Freq & IV \\
\hline VA1 $(n)$ & \multicolumn{3}{|c|}{ (16) } & \multicolumn{3}{|c|}{$(22)$} & \multicolumn{3}{|c|}{ (15) } \\
\hline Herbaceous leaves and flowers & 16.5 & 15 & 0.55 & 28.4 & 22 & 0.64 & 29.4 & 15 & 0.65 \\
\hline Evergreen leaves & 3.2 & 11 & 0.36 & 17.7 & 10 & 0.32 & 16.6 & 11 & 0.45 \\
\hline Deciduous leaves & 0.0 & 0 & 0.00 & 2.7 & 2 & 0.06 & 2.3 & 2 & 0.08 \\
\hline Ferns & 0.1 & 3 & 0.09 & 7.6 & 3 & 0.11 & 8.8 & 8 & 0.31 \\
\hline Buds and twigs & 2.4 & 5 & 0.17 & 14.3 & 10 & 0.30 & 12.5 & 9 & 0.36 \\
\hline Oak and beech fruits & 60.8 & 5 & 0.46 & 1.1 & 1 & 0.03 & 5.3 & 2 & 0.09 \\
\hline Other hard fruits & 0.0 & 0 & 0.00 & 8.6 & 3 & 0.11 & 0.0 & 0 & 0.00 \\
\hline Soft fruits & 12.3 & 3 & 0.16 & 19.5 & 6 & 0.23 & 7.3 & 3 & 0.14 \\
\hline Catkins & 4.9 & 1 & 0.06 & 0.0 & 0 & 0.00 & 17.6 & 4 & 0.22 \\
\hline Aspen flower buds & 0.0 & 0 & 0.00 & 0.0 & 0 & 0.00 & 0.0 & 0 & 0.00 \\
\hline Animal matter & 0.0 & 0 & 0.00 & 0.0 & 0 & 0.00 & 0.3 & 1 & 0.03 \\
\hline $\operatorname{VA} 3(n)$ & \multicolumn{3}{|c|}{ (21) } & \multicolumn{3}{|c|}{ (14) } & \multicolumn{3}{|c|}{ (13) } \\
\hline Herbaceous leaves and flowers & 46.8 & 19 & 0.69 & 44.1 & 13 & 0.69 & 5.9 & 9 & 0.38 \\
\hline Evergreen leaves & 7.6 & 5 & 0.16 & 12.5 & 7 & 0.31 & 0.7 & 3 & 0.12 \\
\hline Deciduous leaves & 0.0 & 0 & 0.00 & 0.0 & 0 & 0.00 & 0.0 & 0 & 0.00 \\
\hline Ferns & 0.1 & 3 & 0.07 & 14.4 & 9 & 0.39 & 2.2 & 6 & 0.24 \\
\hline Buds and twigs & 10.8 & 12 & 0.34 & 28.1 & 9 & 0.46 & 0.7 & 3 & 0.12 \\
\hline Oak and beech fruits & 23.5 & 3 & 0.19 & 0.0 & 0 & 0.00 & 90.0 & 11 & 0.87 \\
\hline Other hard fruits & $\operatorname{tr}$ & 1 & 0.02 & 0.5 & 3 & 0.11 & 0.0 & 0 & 0.00 \\
\hline Soft fruits & 10.8 & 1 & 0.08 & 0.0 & 0 & 0.00 & 0.4 & 1 & 0.04 \\
\hline Catkins & 0.0 & 0 & 0.00 & 0.2 & 1 & 0.04 & 0.1 & 1 & 0.04 \\
\hline Aspen flower buds & 0.0 & 0 & 0.00 & 0.0 & 0 & 0.00 & 0.0 & 0 & 0.00 \\
\hline Animal matter & 0.0 & 1 & 0.02 & 0.1 & 1 & 0.04 & 0.1 & 1 & 0.04 \\
\hline $\mathrm{KY}(n)$ & \multicolumn{3}{|c|}{ (2) } & \multicolumn{3}{|c|}{ (7) } & \multicolumn{3}{|c|}{ (13) } \\
\hline Herbaceous leaves and flowers & 100.0 & 2 & 1.00 & 2.2 & 5 & 0.37 & 42.1 & 11 & 0.6 \\
\hline Evergreen leaves & 0.0 & 0 & 0.00 & 0.3 & 1 & 0.07 & 9.5 & 4 & 0.2 \\
\hline Deciduous leaves & 0.0 & 0 & 0.00 & 0.0 & 0 & 0.00 & 32.3 & 4 & 0.3 \\
\hline Ferns & 0.0 & 0 & 0.00 & 0.2 & 2 & 0.14 & 11.3 & 8 & 0.3 \\
\hline Buds and twigs & 0.0 & 0 & 0.00 & 0.0 & 0 & 0.00 & 1.6 & 3 & 0.1 \\
\hline Oak and beech fruits & 0.0 & 0 & 0.00 & 97.5 & 6 & 0.92 & 0.0 & 0 & 0.0 \\
\hline Other hard fruits & 0.0 & 0 & 0.00 & 0.0 & 0 & 0.00 & 0.6 & 1 & 0.0 \\
\hline Soft fruits & 0.0 & 0 & 0.00 & 0.0 & 0 & 0.00 & 2.2 & 2 & 0.1 \\
\hline Catkins & 0.0 & 0 & 0.00 & 0.0 & 0 & 0.00 & 0.1 & 1 & 0.0 \\
\hline Aspen flower buds & 0.0 & 0 & 0.00 & 0.0 & 0 & 0.00 & 0.0 & 0 & 0.0 \\
\hline Animal matter & 0.0 & 0 & 0.00 & 0.0 & 0 & 0.00 & 0.2 & 2 & 0.1 \\
\hline
\end{tabular}


Table 3. Continued.

\begin{tabular}{|c|c|c|c|c|c|c|c|c|c|}
\hline \multirow{3}{*}{$\begin{array}{l}\text { Site } \\
\quad \text { Forage Class }\end{array}$} & \multicolumn{9}{|c|}{ Year } \\
\hline & \multicolumn{3}{|c|}{2000} & \multicolumn{3}{|c|}{2001} & \multicolumn{3}{|c|}{2002} \\
\hline & Mass & Freq & IV & Mass & Freq & IV & Mass & Freq & IV \\
\hline $\mathrm{NC}(n)$ & \multicolumn{3}{|c|}{ (17) } & \multicolumn{3}{|c|}{$(20)$} & \multicolumn{3}{|c|}{ (16) } \\
\hline Herbaceous leaves and flowers & 54.3 & 16 & 0.74 & 17.6 & 18 & 0.54 & 54.2 & 15 & 0.74 \\
\hline Evergreen leaves & 29.9 & 8 & 0.38 & 6.7 & 9 & 0.26 & 3.1 & 3 & 0.11 \\
\hline Deciduous leaves & 2.3 & 1 & 0.04 & 0.5 & 1 & 0.03 & 4.7 & 1 & 0.05 \\
\hline Ferns & 1.1 & 5 & 0.15 & 1.9 & 8 & 0.21 & 19.3 & 9 & 0.38 \\
\hline Buds and twigs & 6.3 & 9 & 0.30 & 25.6 & 11 & 0.40 & 2.1 & 6 & 0.20 \\
\hline Oak and beech fruits & 5.9 & 1 & 0.06 & 0.0 & 0 & 0.00 & 16.6 & 4 & 0.21 \\
\hline Other hard fruits & 0.4 & 1 & 0.03 & 0.0 & 0 & 0.00 & 0.0 & 0 & 0.00 \\
\hline Soft fruits & 0.0 & 0 & 0.00 & 35.3 & 3 & 0.25 & 0.1 & 1 & 0.03 \\
\hline Catkins & 0.0 & 0 & 0.00 & 12.4 & 4 & 0.16 & 0.0 & 0 & 0.00 \\
\hline Aspen flower buds & 0.0 & 0 & 0.00 & 0.0 & 0 & 0.00 & 0.0 & 0 & 0.00 \\
\hline Animal matter & 0.0 & 0 & 0.00 & 0.1 & 2 & 0.05 & 0.0 & 0 & 0.00 \\
\hline
\end{tabular}

${ }^{a}$ Importance Value (IV) = (aggregate mass (\%)/ $100+$ occurrence $\left.(\%) / 100\right) / 2$

${ }^{\mathrm{b}} \mathrm{PA}=$ Pennsylvania, MD = Maryland; WV1 = West Virginia 1; WV2 = West Virginia 2; VA1 = Virginia 1; VA3 = Virginia 3; KY = Kentucky; $\mathrm{NC}=$ North Carolina. 
Table 4. Mean Importance Values ${ }^{\mathrm{a}}$ of forages from crops of ruffed grouse collected in March and April, 2000-2002 in Michigan, Wisconsin, and Minnesota (Northern) and 8 study sites in the central and southern Appalachians ${ }^{\mathrm{b}}$. Only forages with IV $>0.05$ in at least 1 year are presented. Abbreviations are 1.=leaves, fl.=flowers, c.=catkins, bt.=buds and twigs, fr. $=$ fruit.

\begin{tabular}{|c|c|c|c|c|c|c|c|c|c|}
\hline \multirow[b]{2}{*}{ Forage } & \multicolumn{9}{|c|}{ Site $^{b}$} \\
\hline & Northern & PA & MD & WV1 & WV2 & VA1 & VA3 & KY & $\mathrm{NC}$ \\
\hline Alder c. (Alnus spp.) & 0.05 & & & & & & & & \\
\hline Animal matter & 0.10 & 0.06 & 0.05 & & 0.04 & & & 0.02 & 0.02 \\
\hline Aspen fl. (Populus spp.) & 0.38 & 0.10 & & & & & & & \\
\hline Avens 1. (Geum spp.) & 0.10 & 0.14 & 0.15 & & & 0.04 & & 0.03 & 0.04 \\
\hline Azalea 1. (Rhododendron spp.) & & & & & & & & & 0.02 \\
\hline Beech fr. (Fagus grandifolia) & & 0.02 & & 0.05 & & & & 0.31 & \\
\hline $\begin{array}{l}\text { Birdsfoot-trefoil 1. (Lotus } \\
\text { corniculatus) }\end{array}$ & & & 0.20 & & & 0.05 & & 0.03 & \\
\hline Black birch bt. (Betula lenta) & 0.04 & 0.07 & 0.11 & 0.05 & & 0.02 & & & 0.06 \\
\hline Black birch c. & & 0.10 & 0.03 & 0.07 & & 0.03 & & & 0.05 \\
\hline $\begin{array}{l}\text { Blueberry / huckleberry bt. } \\
\text { (Vaccinium spp. / Gaylussacia } \\
\text { spp.) }\end{array}$ & & 0.22 & & 0.04 & 0.19 & 0.09 & 0.11 & & 0.07 \\
\hline Cherry bt. (Prunus spp.) & & 0.04 & & 0.02 & & & & & \\
\hline Cherry fr. & & & 0.06 & & & & & & \\
\hline $\begin{array}{l}\text { Christmas fern 1. (Polystichum } \\
\text { acrostichoides) }\end{array}$ & & & 0.14 & 0.06 & 0.06 & 0.14 & 0.21 & 0.11 & 0.20 \\
\hline Cinquefoil 1. (Potentilla spp.) & 0.07 & 0.15 & 0.21 & 0.13 & 0.32 & 0.18 & 0.24 & & 0.19 \\
\hline Clover 1. (Trifolium spp.) & 0.02 & & & 0.15 & 0.07 & 0.05 & 0.13 & & 0.18 \\
\hline Coltsfoot fl. (Tussilago farfara) & & 0.16 & 0.03 & 0.06 & 0.07 & 0.12 & 0.23 & & \\
\hline Dewberry 1. (Rubus hispidus) & & 0.04 & & 0.10 & & 0.02 & & & \\
\hline Grape fr. (Vitis spp.) & & 0.02 & & & & & & & \\
\hline Greenbrier fr. (Smilax spp.) & & 0.02 & & 0.11 & 0.08 & 0.07 & 0.04 & & 0.07 \\
\hline Greenbrier 1. & & & & 0.06 & 0.05 & 0.12 & 0.04 & 0.08 & 0.08 \\
\hline Hawkweed 1. (Hieracium spp.) & & 0.04 & & 0.14 & 0.14 & 0.06 & & & 0.05 \\
\hline Hornbeam c. (Ostrya virginiana) & 0.02 & & & & & 0.03 & & & \\
\hline Maple fr. (Acer spp.) & & 0.05 & 0.06 & & 0.16 & 0.02 & 0.04 & & \\
\hline
\end{tabular}


Table 4. Continued

\begin{tabular}{|c|c|c|c|c|c|c|c|c|c|}
\hline \multirow[b]{2}{*}{ Forage } & \multicolumn{9}{|c|}{ Site } \\
\hline & Northern & PA & MD & WV1 & WV2 & VA1 & VA3 & KY & $\mathrm{NC}$ \\
\hline $\begin{array}{l}\text { Mountain laurel bt. (Kalmia } \\
\text { latifolia) }\end{array}$ & & & & 0.10 & 0.09 & 0.04 & 0.04 & & 0.02 \\
\hline Mountain laurel 1. & & 0.05 & & 0.23 & 0.23 & 0.16 & 0.14 & & 0.23 \\
\hline Multiflora rose 1. (Rosa multiflora) & & & & 0.06 & & 0.03 & & 0.10 & 0.03 \\
\hline Oak fr. (Quercus spp.) & & 0.22 & 0.10 & 0.04 & 0.27 & 0.19 & 0.35 & & 0.09 \\
\hline Partridgeberry 1. (Mitchella repens) & 0.03 & 0.07 & & & 0.05 & 0.10 & & 0.03 & \\
\hline Pyrola spp. 1. & 0.12 & & & & & & & & \\
\hline Ragwort 1. (Senecio spp.) & & & & & & & 0.04 & 0.03 & 0.04 \\
\hline Serviceberry bt. (Amelanchier spp.) & & 0.08 & 0.03 & 0.03 & 0.02 & 0.09 & 0.07 & & 0.06 \\
\hline Sorrel 1. (Rumex acetosella) & & & 0.05 & & & & & & 0.05 \\
\hline Strawberry 1. (Fragaria spp.) & 0.25 & & 0.07 & & & & 0.02 & & 0.09 \\
\hline Sumac fr. (Rhus spp.) & & 0.12 & 0.02 & & & & & 0.03 & \\
\hline Trailing arbutus 1. (Epigaea repens) & & 0.04 & & & 0.04 & 0.06 & 0.03 & & 0.02 \\
\hline Viburnum spp. fr. & & & & & & 0.04 & & & \\
\hline $\begin{array}{l}\text { Wintergreen fr. (Gaultheria } \\
\text { procumbens) }\end{array}$ & & 0.03 & & 0.06 & 0.05 & 0.07 & & & \\
\hline Wintergreen 1. & 0.02 & 0.03 & & & & & & & \\
\hline $\begin{array}{l}\text { Witch-hazel bt. (Hamamelis } \\
\text { virginiana) }\end{array}$ & & & & 0.02 & 0.02 & 0.04 & & & \\
\hline Witch-hazel fr. & & & & 0.02 & 0.16 & 0.03 & & & \\
\hline $\begin{array}{l}\text { Wood fern 1. (Dryopteris } \\
\text { camyloptera) }\end{array}$ & & 0.07 & 0.23 & 0.15 & & 0.04 & 0.04 & 0.02 & 0.07 \\
\hline $\begin{array}{l}\text { Yellow birch c. (Betula } \\
\text { alleghaniensis) }\end{array}$ & & & & 0.05 & & & & & \\
\hline
\end{tabular}


Table 5. Carcass fat (\%) of ruffed grouse collected March-April 2000-2002 in Michigan, Wisconsin, and Minnesota (Northern) and at 8 sites in the central and southern Appalachians $\mathrm{a}^{\mathrm{a}}$.

\begin{tabular}{|c|c|c|c|c|c|c|c|c|c|}
\hline \multirow{3}{*}{$\begin{array}{l}\text { Site }^{\mathrm{a}} \\
\text { Sex }\end{array}$} & \multicolumn{9}{|c|}{ Year } \\
\hline & \multicolumn{3}{|c|}{2000} & \multicolumn{3}{|c|}{2001} & \multicolumn{3}{|c|}{2002} \\
\hline & $n$ & Mean & SE & $n$ & Mean & $\mathrm{SE}$ & $n$ & Mean & SE \\
\hline \multicolumn{10}{|l|}{ Northern } \\
\hline Female & 16 & 7.9 & 0.9 & 15 & 6.7 & 1.0 & 5 & 7.3 & 3.0 \\
\hline Male & 16 & 5.6 & 0.7 & 18 & 4.2 & 0.4 & 10 & 4.7 & 0.4 \\
\hline Combined & 32 & 6.7 & 0.6 & 33 & 5.4 & 0.5 & 15 & 5.6 & 1.0 \\
\hline \multicolumn{10}{|l|}{ PA } \\
\hline Female & 8 & 15.1 & 2.7 & 7 & 8.6 & 2.1 & 8 & 16.2 & 2.9 \\
\hline Male & 11 & 5.6 & 0.5 & 8 & 9.7 & 2.3 & 6 & 10.0 & 2.5 \\
\hline Combined & 19 & 10.3 & 1.2 & 15 & 9.1 & 1.3 & 14 & 13.1 & 1.4 \\
\hline \multicolumn{10}{|l|}{$\mathrm{MD}$} \\
\hline Female & 7 & 12.9 & 2.5 & 7 & 8.0 & 1.6 & 5 & 25.9 & 2.6 \\
\hline Male & 12 & 7.0 & 0.9 & 3 & 7.7 & 2.1 & 2 & 15.9 & 4.2 \\
\hline Combined & 19 & 9.9 & 1.2 & 10 & 7.9 & 1.8 & 7 & 20.9 & 2.1 \\
\hline \multicolumn{10}{|l|}{ WV1 } \\
\hline Female & 6 & 7.8 & 1.6 & 6 & 8.8 & 0.6 & 10 & 10.4 & 1.6 \\
\hline Male & 8 & 5.1 & 0.7 & 2 & 14.6 & 8.0 & 7 & 6.9 & 1.7 \\
\hline Combined & 14 & 6.4 & 1.4 & 8 & 11.7 & 2.1 & 17 & 8.6 & 1.3 \\
\hline \multicolumn{10}{|l|}{ WV2 } \\
\hline Female & 5 & 12.0 & 3.0 & 7 & 7.2 & 0.9 & 6 & 14.0 & 4.4 \\
\hline Male & 8 & 7.2 & 1.3 & 4 & 6.6 & 0.7 & 9 & 4.1 & 0.4 \\
\hline Combined & 13 & 9.6 & 1.5 & 11 & 6.9 & 1.6 & 15 & 9.0 & 1.3 \\
\hline \multicolumn{10}{|l|}{ VA1 } \\
\hline Female & 11 & 25.0 & 2.4 & 8 & 14.6 & 1.9 & 8 & 13.2 & 3.5 \\
\hline Male & 5 & 9.8 & 1.6 & 16 & 10.5 & 1.0 & 9 & 6.9 & 0.6 \\
\hline Combined & 16 & 17.5 & 1.4 & 24 & 12.5 & 1.1 & 17 & 10.0 & 1.3 \\
\hline \multicolumn{10}{|l|}{ VA3 } \\
\hline Female & 12 & 15.6 & 2.4 & 6 & 10.1 & 1.8 & 8 & 27.0 & 1.0 \\
\hline Male & 10 & 7.1 & 1.1 & 8 & 6.9 & 1.1 & 5 & 19.0 & 2.5 \\
\hline Combined & 22 & 11.3 & 1.1 & 14 & 8.5 & 1.4 & 13 & 23.0 & 1.5 \\
\hline \multicolumn{10}{|l|}{ KY } \\
\hline Female & 3 & 11.2 & 1.6 & 2 & 28.3 & 4.3 & 6 & 11.7 & 1.5 \\
\hline Male & 1 & 5.1 & . & 5 & 16.4 & 1.0 & 10 & 8.8 & 1.4 \\
\hline Combined & 4 & 8.2 & 2.9 & 7 & 22.3 & 2.1 & 16 & 10.2 & 1.3 \\
\hline \multicolumn{10}{|l|}{$\mathrm{NC}$} \\
\hline Female & 8 & 5.6 & 1.0 & 9 & 11.7 & 2.2 & 7 & 8.8 & 1.3 \\
\hline Male & 12 & 5.2 & 0.5 & 11 & 7.3 & 0.7 & 10 & 7.7 & 1.4 \\
\hline Combined & 20 & 5.4 & 1.2 & 20 & 9.5 & 1.1 & 17 & 8.2 & 1.3 \\
\hline
\end{tabular}


Table 6. Results of information-theoretic model selection to evaluate competing a-priori models predicting mean pre-breeding carcass fat (\%) of ruffed grouse collected from 8 sites in the central and southern Appalachians, 2000-2002 using crop food category Importance Values ${ }^{\mathrm{a}}$ and the control variable $\operatorname{Sex}(n=48)$. Statistics presented are number of parameters $(K)$, Akaike's Information Criterion adjusted for small sample size $\left(\mathrm{AIC}_{c}\right), \mathrm{AIC}_{c}$ difference $\left(\Delta_{i}\right)$, and $\mathrm{AIC}_{c}$ weight $\left(\omega_{i}\right)$.

\begin{tabular}{|c|c|c|c|c|}
\hline Model Parameters & $K$ & $\mathrm{AIC}_{c}$ & $\Delta_{i}$ & $\omega_{i}$ \\
\hline \multicolumn{5}{|l|}{$\begin{array}{l}\text { HERB, EVERGREEN, FERN, BUD, OAKBEECH, SOFTMAST, } \\
\text { HARDMAST, CATKIN, EVERGREEN x OAKBEECH, }\end{array}$} \\
\hline HERBXEVERGREEN & 13 & -99.0 & 8.8 & 0.01 \\
\hline OAKBEECH & 3 & -88.7 & 19.0 & 0.00 \\
\hline EVERGREEN, OAKBEECH & 4 & -89.1 & 18.6 & 0.00 \\
\hline EVERGREEN x OAKBEECH & 3 & -77.1 & 30.6 & 0.00 \\
\hline EVERGREEN, FERN, OAKBEECH & 5 & -92.3 & 15.4 & 0.00 \\
\hline HERB & 3 & -71.4 & 36.4 & 0.00 \\
\hline EVERGREEN & 3 & -69.0 & 38.7 & 0.00 \\
\hline EVERGREEN, FERN, BUD, OAKBEECH, CATKIN & 7 & -92.5 & 15.2 & 0.00 \\
\hline OAKBEECH, SOFTMAST, HARDMAST & 5 & -84.4 & 23.3 & 0.00 \\
\hline OAKBEECH, SOFTMAST & 4 & -86.9 & 20.8 & 0.00 \\
\hline BUD, CATKIN & 4 & -76.7 & 31.0 & 0.00 \\
\hline EVERGREEN, FERN, BUD, CATKIN & 6 & -72.5 & 35.3 & 0.00 \\
\hline HERB, EVERGREEN, FERN, BUD, CATKIN & 7 & -77.4 & 30.3 & 0.00 \\
\hline HERB x EVERGREEN & 3 & -70.4 & 37.3 & 0.00 \\
\hline OAKBEECH, HERB x EVERGREEN & 4 & -89.0 & 18.7 & 0.00 \\
\hline Sex, OAKBEECH & 4 & -99.0 & 8.7 & 0.01 \\
\hline Sex, EVERGREEN, OAKBEECH & 5 & -102.8 & 5.0 & 0.04 \\
\hline Sex, EVERGREEN x OAKBEECH & 4 & -81.4 & 26.4 & 0.00 \\
\hline Sex, EVERGREEN, FERN, OAKBEECH & 6 & -107.7 & 0.0 & 0.48 \\
\hline Sex, HERB & 4 & -83.5 & 24.3 & 0.00 \\
\hline Sex, EVERGREEN & 4 & -81.5 & 26.2 & 0.00 \\
\hline Sex, EVERGREEN, FERN, BUD, OAKBEECH, CATKIN & 8 & -107.4 & 0.3 & 0.41 \\
\hline Sex, OAKBEECH, SOFTMAST, HARDMAST & 6 & -95.5 & 12.3 & 0.00 \\
\hline Sex, OAKBEECH, SOFTMAST & 5 & -100.6 & 7.1 & 0.01 \\
\hline Sex, BUD, CATKIN & 5 & -88.9 & 18.8 & 0.00 \\
\hline Sex, EVERGREEN, FERN, BUD, CATKIN & 7 & -84.6 & 23.1 & 0.00 \\
\hline Sex, HERB, EVERGREEN, FERN, BUD, CATKIN & 8 & -96.0 & 11.8 & 0.00 \\
\hline Sex, HERB x EVERGREEN & 4 & -83.8 & 23.9 & 0.00 \\
\hline Sex, OAKBEECH, HERB x EVERGREEN & 5 & -102.8 & 4.9 & 0.04 \\
\hline
\end{tabular}


Table 7. Results of information-theoretic model selection to evaluate competing a-priori models predicting mean pre-breeding carcass fat (\%) of ruffed grouse collected from 8 sites in the central and southern Appalachians, 2000-2002 using control variables (Sex, Site, Forest type) and Mast Index ${ }^{\mathrm{a}}$ values $(n=48)$. Statistics presented are number of parameters $(K)$, Akaike's Information Criterion adjusted for small sample size $\left(\mathrm{AIC}_{c}\right), \mathrm{AIC}_{c}$ difference $\left(\Delta_{i}\right)$, and $\mathrm{AIC}_{c}$ weight $\left(\omega_{i}\right)$.

\begin{tabular}{lcccc}
\hline Model parameters & $K$ & $\mathrm{AIC}_{c}$ & $\Delta_{i}$ & $\omega_{i}$ \\
\hline Site & 3 & 69.5 & 14.2 & 0.00 \\
Sex & 3 & 58.2 & 2.9 & 0.09 \\
Mast Index & 3 & 66.5 & 11.2 & 0.00 \\
Site, Mast Index & 4 & 68.0 & 12.7 & 0.00 \\
Sex, Site & 4 & 59.4 & 4.1 & 0.05 \\
Sex, Mast Index & 4 & 55.6 & 0.3 & 0.32 \\
Sex, Site, Mast Index & 5 & 55.3 & 0.0 & 0.37 \\
Forest Type & 3 & 69.2 & 13.9 & 0.00 \\
Forest Type, Mast Index & 4 & 68.5 & 13.2 & 0.00 \\
Sex, Forest Type & 4 & 60.0 & 4.7 & 0.04 \\
Sex, Forest Type, Mast Index & 5 & 57.8 & 2.5 & 0.11 \\
Mast Index x Forest Type & 3 & 71.6 & 16.3 & 0.00 \\
Sex, Mast Index x Forest Type & 4 & 60.7 & 5.4 & 0.02 \\
\hline
\end{tabular}

\footnotetext{
${ }^{a}$ Mast Index was calculated as the sum of the rankings of red/black oak, white oak, chestnut oak, and beech production
} as none (0), light (1), moderate (2), or heavy (3) 
Table 8. Results of information-theoretic model selection to evaluate competing a-priori models predicting pre-breeding carcass fat $(\%)$ of ruffed grouse collected from 8 sites in the central and southern Appalachians, 2000-2002 using control variables (Sex, Site, Forest type) and the presence/absence of acorns or beechnuts in crop (Mast; $n=326)$. Statistics presented are number of parameters $(K)$, Akaike's Information Criterion (AIC), AIC difference $\left(\Delta_{i}\right)$, and AIC weight $\left(\omega_{i}\right)$.

\begin{tabular}{llcrc}
\hline Model parameters & $K$ & AIC & \multicolumn{1}{c}{$\Delta_{i}$} & $\omega_{i}$ \\
\hline Site & 3 & 601.1 & 104.5 & 0.00 \\
Sex & 3 & 580.6 & 84.0 & 0.00 \\
Mast & 3 & 579.5 & 82.9 & 0.00 \\
Site, Mast & 4 & 548.4 & 51.8 & 0.00 \\
Sex, Site & 4 & 543.6 & 47.0 & 0.00 \\
Sex, Mast & 4 & 535.5 & 38.9 & 0.00 \\
Sex, Site, Mast & 5 & 496.6 & 0.0 & 1.00 \\
Forest Type & 3 & 629.1 & 132.5 & 0.00 \\
Forest Type, Mast & 4 & 580.9 & 84.3 & 0.00 \\
Sex, Forest Type & 4 & 577.6 & 81.0 & 0.00 \\
Sex, Forest Type, Mast & 5 & 534.9 & 38.3 & 0.00 \\
Mast x Forest Type & 3 & 580.7 & 84.1 & 0.00 \\
Sex, Mast x Forest Type & 4 & 536.8 & 40.2 & 0.00 \\
\hline
\end{tabular}


Table 9. Results of information-theoretic model selection to evaluate competing a-priori models

predicting pre-breeding reproductive organ mass for females (ovary mass + oviduct mass) and males

(paired testes mass) ruffed grouse collected from 8 sites in the central and southern Appalachians, 2000-

2002 using \% carcass fat, crop-free body mass (MASS), and control variables (Site, Year). Statistics

presented are number of parameters $(K)$, Akaike's Information Criterion adjusted for small sample size

$\left(\mathrm{AIC}_{c}\right), \mathrm{AIC}_{c}$ difference $\left(\Delta_{i}\right)$, and $\mathrm{AIC}_{c}$ weight $\left(\omega_{i}\right)$.

\begin{tabular}{|c|c|c|c|c|c|c|c|}
\hline \multirow[b]{2}{*}{ Model parameters } & \multirow[b]{2}{*}{ K } & \multicolumn{3}{|c|}{ Female $(n=160)$} & \multicolumn{3}{|c|}{ Male $(n=166)$} \\
\hline & & $\mathrm{AIC}_{c}$ & $\Delta_{i}$ & $\omega_{i}$ & $\mathrm{AIC}_{c}$ & $\Delta_{i}$ & $\omega_{i}$ \\
\hline Site & 3 & 255.6 & 54.9 & 0.00 & 140.4 & 5.5 & 0.02 \\
\hline Year & 4 & 221.0 & 20.3 & 0.00 & 135.8 & 0.9 & 0.16 \\
\hline Mass & 3 & 253.9 & 53.2 & 0.00 & 143.1 & 8.2 & 0.00 \\
\hline$\%$ Fat & 3 & 243.3 & 42.6 & 0.00 & 141.1 & 6.2 & 0.01 \\
\hline Site, Year & 5 & 215.6 & 14.9 & 0.00 & 135.3 & 0.4 & 0.21 \\
\hline Site, Mass & 4 & 249.2 & 48.5 & 0.00 & 143.3 & 8.4 & 0.00 \\
\hline Site, $\%$ Fat & 4 & 251.6 & 50.9 & 0.00 & 147.8 & 12.9 & 0.00 \\
\hline Year, Mass & 5 & 218.3 & 17.6 & 0.00 & 138.8 & 3.9 & 0.04 \\
\hline Year, \% Fat & 5 & 204.0 & 3.3 & 0.15 & 134.9 & 0.0 & 0.26 \\
\hline Mass, \% Fat & 4 & 250.4 & 49.7 & 0.00 & 146.1 & 11.2 & 0.00 \\
\hline Site, Year, Mass & 6 & 209.8 & 9.1 & 0.00 & 137.6 & 2.7 & 0.07 \\
\hline Site, Year, \% Fat & 6 & 200.7 & 0.0 & 0.80 & 135.7 & 0.8 & 0.17 \\
\hline Site, Mass, \% Fat & 5 & 248.4 & 47.7 & 0.00 & 146.4 & 11.5 & 0.00 \\
\hline Year, Mass, \% Fat & 6 & 212.8 & 12.1 & 0.00 & 139.9 & 5.0 & 0.02 \\
\hline Site, Year, Mass, $\%$ Fat & 7 & 207.1 & 6.4 & 0.03 & 139.5 & 4.6 & 0.03 \\
\hline
\end{tabular}


Table 10. Results of information-theoretic model selection to evaluate 8 a-priori models and 3 post-hoc models (models including fat class) predicting mean incubation date, clutch size, and hatching success of radio-transmittered ruffed grouse nests on 8 sites in the central and southern Appalachians, 2000-2002 using site, year, mean pre-breeding carcass fat (\%) and carcass fat class (low, moderate, high) of grouse collected from same sites $(n=22)$. Statistics presented are number of parameters $(K)$, Akaike's Information Criterion adjusted for small sample size $\left(\mathrm{AIC}_{c}\right), \mathrm{AIC}_{c}$ difference $\left(\Delta_{i}\right)$, and $\mathrm{AIC} c$ weight $\left(\omega_{i}\right)$.

\begin{tabular}{|c|c|c|c|c|c|c|c|c|c|c|}
\hline \multirow[b]{2}{*}{ Model parameters } & \multirow[b]{2}{*}{ K } & \multicolumn{3}{|c|}{ Incubation date } & \multicolumn{3}{|c|}{ Clutch size } & \multicolumn{3}{|c|}{ Hatching success } \\
\hline & & $\mathrm{AIC}_{c}$ & $\Delta_{i}$ & $\omega_{i}$ & $\mathrm{AIC}_{c}$ & $\Delta_{i}$ & $\omega_{i}$ & $\mathrm{AIC}_{c}$ & $\Delta_{i}$ & $\omega_{i}$ \\
\hline Site & 3 & 129.7 & 10.9 & 0.00 & 48.1 & 2.0 & 0.16 & -30.1 & 0.0 & 0.81 \\
\hline Year & 4 & 129.0 & 10.2 & 0.01 & 47.0 & 0.9 & 0.28 & -24.6 & 5.5 & 0.05 \\
\hline$\%$ Fat & 3 & 139.9 & 21.1 & 0.00 & 53.5 & 7.4 & 0.01 & -20.8 & 9.3 & 0.00 \\
\hline Site, Year & 5 & 121.4 & 2.6 & 0.23 & 47.0 & 0.9 & 0.27 & -24.6 & 5.5 & 0.05 \\
\hline Site, $\%$ Fat & 4 & 132.1 & 13.3 & 0.00 & 53.5 & 7.4 & 0.01 & -20.8 & 9.3 & 0.01 \\
\hline Year, \% Fat & 5 & 129.7 & 10.9 & 0.00 & 52.3 & 6.2 & 0.02 & -16.4 & 13.7 & 0.00 \\
\hline Site, Year, \% Fat & 6 & 123.7 & 4.9 & 0.07 & 52.3 & 6.2 & 0.02 & -16.4 & 13.7 & 0.00 \\
\hline Year x \% Fat & 4 & 139.7 & 20.9 & 0.00 & 63.8 & 17.7 & 0.00 & -4.7 & 25.4 & 0.00 \\
\hline Fat Class & 4 & 128.5 & 9.7 & 0.01 & 47.0 & 0.9 & 0.27 & -23.6 & 6.5 & 0.03 \\
\hline Site, Fat Class & 5 & 123.6 & 4.8 & 0.08 & 47.0 & 0.9 & 0.27 & -23.6 & 6.5 & 0.03 \\
\hline Year, Fat Class & 6 & 118.8 & 0.0 & 0.84 & 46.1 & 0.0 & 0.43 & -18.1 & 12.0 & 0.00 \\
\hline
\end{tabular}


Table 11. Results of information-theoretic model selection to evaluate 8 a-priori models and 3 post-hoc models (models including fat class) predicting nest success and hen success of radiotransmittered ruffed grouse nests and females on 8 sites in the central and southern Appalachians, 2000-2002 using site, year, mean pre-breeding carcass fat (\%) and carcass fat class (low, moderate, high) of grouse collected from same sites $(n=22)$. Statistics presented are number of parameters $(K)$, Akaike's Information Criterion adjusted for small sample size $\left(\operatorname{AIC}_{c}\right), \operatorname{AIC}_{c}$ difference $\left(\Delta_{i}\right)$, and $\operatorname{AIC}_{c}$ weight $\left(\omega_{i}\right)$.

\begin{tabular}{|c|c|c|c|c|c|c|c|}
\hline \multirow[b]{2}{*}{ Model parameters } & \multirow[b]{2}{*}{ K } & \multicolumn{3}{|c|}{ Nest success } & \multicolumn{3}{|c|}{ Female success } \\
\hline & & $\mathrm{AIC}_{c}$ & $\Delta_{i}$ & $\omega_{i}$ & $\mathrm{AIC}_{c}$ & $\Delta_{i}$ & $\omega_{i}$ \\
\hline Site & 3 & 0.7 & 0.0 & 0.82 & 3.1 & 0.0 & 0.58 \\
\hline Year & 4 & 7.2 & 6.5 & 0.03 & 5.9 & 2.8 & 0.14 \\
\hline$\%$ Fat & 3 & 10.1 & 9.4 & 0.01 & 8.8 & 5.7 & 0.03 \\
\hline Site, Year & 5 & 7.0 & 6.3 & 0.03 & 8.3 & 5.2 & 0.04 \\
\hline Site, $\%$ Fat & 4 & 8.2 & 7.5 & 0.02 & 10.9 & 7.8 & 0.01 \\
\hline Year, \% Fat & 5 & 14.9 & 14.2 & 0.00 & 13.5 & 10.4 & 0.00 \\
\hline Site, Year, \% Fat & 6 & 14.4 & 13.7 & 0.00 & 15.9 & 12.8 & 0.00 \\
\hline Year $\mathrm{x} \%$ Fat & 4 & 25.6 & 24.9 & 0.00 & 24.6 & 21.5 & 0.00 \\
\hline Fat Class & 4 & 7.1 & 6.4 & 0.03 & 6.0 & 2.9 & 0.14 \\
\hline Site, Fat Class & 5 & 6.2 & 5.5 & 0.05 & 8.4 & 5.3 & 0.04 \\
\hline Year, Fat Class & 6 & 11.7 & 11.0 & 0.00 & 10.7 & 7.6 & 0.01 \\
\hline
\end{tabular}


Table 12. Results of information-theoretic model selection to evaluate 8 a-priori models and 3 post-hoc models (models including fat class) predicting realized ${ }^{\text {a }}$ chick survival and Recruitment Indices (number chicks alive at 5 weeks post-hatch per female alive on April 1) of radio-transmittered ruffed grouse on 8 sites in the central and southern Appalachians, 2000-2002 using site, year, mean pre-breeding carcass fat (\%) and carcass fat class (low, moderate, high) of grouse collected from same sites $(n=22)$. Statistics presented are number of parameters $(K)$, Akaike's Information Criterion adjusted for small sample size $\left(\mathrm{AIC}_{c}\right), \mathrm{AIC}_{c}$ difference $\left(\Delta_{i}\right)$, and $\mathrm{AIC}_{c}$ weight $\left(\omega_{i}\right)$.

\begin{tabular}{|c|c|c|c|c|c|c|c|c|c|c|}
\hline \multirow[b]{2}{*}{ Model parameters } & \multirow[b]{2}{*}{ K } & \multicolumn{3}{|c|}{ 3-week survival } & \multicolumn{3}{|c|}{ 5-week survival } & \multicolumn{3}{|c|}{ Recruitment Index } \\
\hline & & $\mathrm{AIC}_{c}$ & $\Delta_{i}$ & $\omega_{i}$ & $\mathrm{AIC}_{c}$ & $\Delta_{i}$ & $\omega_{i}$ & $\mathrm{AIC}_{c}$ & $\Delta_{i}$ & $\omega_{i}$ \\
\hline Site & 3 & -0.1 & 7.2 & 0.01 & -12.1 & 6.0 & 0.03 & 73.8 & 18.8 & 0.00 \\
\hline Year & 4 & 2.9 & 10.2 & 0.00 & -7.0 & 11.1 & 0.00 & 69.0 & 14.0 & 0.00 \\
\hline$\%$ Fat & 3 & 5.3 & 12.6 & 0.00 & -6.4 & 11.7 & 0.00 & 75.1 & 20.1 & 0.00 \\
\hline Site, Year & 5 & 5.4 & 12.7 & 0.00 & -5.0 & 13.1 & 0.00 & 71.5 & 16.5 & 0.00 \\
\hline Site, $\%$ Fat & 4 & 7.6 & 14.9 & 0.00 & -4.8 & 13.3 & 0.00 & 77.4 & 22.4 & 0.00 \\
\hline Year, \% Fat & 5 & 10.1 & 17.4 & 0.00 & -0.6 & 17.5 & 0.00 & 71.1 & 16.1 & 0.00 \\
\hline Site, Year, \% Fat & 6 & 12.6 & 19.9 & 0.00 & 1.6 & 19.7 & 0.00 & 73.6 & 18.6 & 0.00 \\
\hline Year $\times \%$ Fat & 4 & 20.5 & 27.8 & 0.00 & 10.1 & 28.2 & 0.00 & 81.5 & 26.5 & 0.00 \\
\hline Fat Class & 4 & -7.3 & 0.0 & 0.45 & -18.1 & 0.0 & 0.66 & 61.1 & 6.1 & 0.04 \\
\hline Site, Fat Class & 5 & -7.3 & 0.0 & 0.45 & -16.3 & 1.8 & 0.27 & 61.1 & 6.1 & 0.04 \\
\hline Year, Fat Class & 6 & -4.1 & 3.2 & 0.09 & -13.6 & 4.5 & 0.07 & 55.0 & 0.0 & 0.91 \\
\hline
\end{tabular}


Table 13. Results of information-theoretic model selection to evaluate 8 a-priori models and 3 post-hoc models (models including fat class) predicting potential ${ }^{\mathrm{a}}$ chick survival and Recruitment Indices (number chicks alive at 5 weeks post-hatch per female alive on April 1) of radio-transmittered ruffed grouse on 8 sites in the central and southern Appalachians, 20002002 using site, year, mean pre-breeding carcass fat (\%) and carcass fat class (low, moderate, high) of grouse collected from same sites $(n=22)$. Statistics presented are number of parameters $(K)$, Akaike's Information Criterion adjusted for small sample size $\left(\mathrm{AIC}_{c}\right), \mathrm{AIC}_{c}$ difference $\left(\Delta_{i}\right)$, and $\mathrm{AIC}_{c}$ weight $\left(\omega_{i}\right)$.

\begin{tabular}{|c|c|c|c|c|c|c|c|c|c|c|}
\hline \multirow[b]{2}{*}{ Model parameters } & \multirow[b]{2}{*}{ K } & \multicolumn{3}{|c|}{ 3-week survival } & \multicolumn{3}{|c|}{ 5-week survival } & \multicolumn{3}{|c|}{ Recruitment Index } \\
\hline & & $\mathrm{AIC}_{c}$ & $\Delta_{i}$ & $\omega_{i}$ & $\mathrm{AIC}_{c}$ & $\Delta_{i}$ & $\omega_{i}$ & $\mathrm{AIC}_{c}$ & $\Delta_{i}$ & $\omega_{i}$ \\
\hline Site & 3 & -0.3 & 8.4 & 0.01 & -8.5 & 8.3 & 0.01 & 73.9 & 20.0 & 0.00 \\
\hline Year & 4 & 3.0 & 11.7 & 0.00 & -3.5 & 13.3 & 0.00 & 69.9 & 16.0 & 0.00 \\
\hline$\%$ Fat & 3 & 4.9 & 13.6 & 0.00 & -2.9 & 13.9 & 0.00 & 75.2 & 21.3 & 0.00 \\
\hline Site, Year & 5 & 5.3 & 14.0 & 0.00 & -1.9 & 14.9 & 0.00 & 72.1 & 18.2 & 0.00 \\
\hline Site, $\%$ Fat & 4 & 6.9 & 15.6 & 0.00 & -2.1 & 14.7 & 0.00 & 77.0 & 23.1 & 0.00 \\
\hline Year, \% Fat & 5 & 9.5 & 18.2 & 0.00 & 3.1 & 19.9 & 0.00 & 71.8 & 17.9 & 0.00 \\
\hline Site, Year, \% Fat & 6 & 11.8 & 20.5 & 0.00 & 4.7 & 21.5 & 0.00 & 73.9 & 20.0 & 0.00 \\
\hline Year $x \%$ Fat & 4 & 19.7 & 28.4 & 0.00 & 13.8 & 30.6 & 0.00 & 81.8 & 27.9 & 0.00 \\
\hline Fat Class & 4 & -8.7 & 0.0 & 0.46 & -16.8 & 0.0 & 0.64 & 58.8 & 4.9 & 0.08 \\
\hline Site, Fat Class & 5 & -8.7 & 0.0 & 0.46 & -15.5 & 1.3 & 0.33 & 61.2 & 7.3 & 0.02 \\
\hline Year, Fat Class & 6 & -5.2 & 3.5 & 0.08 & -10.8 & 6.0 & 0.03 & 53.9 & 0.0 & 0.90 \\
\hline
\end{tabular}

${ }^{a}$ Potential chick survival and Recruitment Indices do not include broods of females that were killed prior to the brood count used to calculate parameters. 
Table 14. Mean post-hatch reproductive parameters of central and southern Appalachian study sites by condition class of collected ruffed grouse, 2000-2002. For all reproductive parameters, significant differences $(P<0.05)$ were found using contrast analyses between the following class means: low vs. high, and low vs. moderate and high combined. No differences were found between high vs. low and moderate combined.

\begin{tabular}{|c|c|c|c|c|c|c|c|c|c|c|c|c|c|c|c|}
\hline \multirow[b]{2}{*}{ Condition class } & \multirow[b]{2}{*}{$n$} & \multicolumn{2}{|c|}{ Carcass fat $(\%)$} & \multicolumn{2}{|c|}{$\begin{array}{c}\text { Realized } \\
\text { 3-week survival }\end{array}$} & \multicolumn{2}{|c|}{$\begin{array}{c}\text { Potential } \\
\text { 3-week survival }\end{array}$} & \multicolumn{2}{|c|}{$\begin{array}{c}\text { Realized } \\
\text { 5-week survival }\end{array}$} & \multicolumn{2}{|c|}{$\begin{array}{c}\text { Potential } \\
\text { 5-week survival }\end{array}$} & \multicolumn{2}{|c|}{$\begin{array}{c}\text { Realized } \\
\text { Recruitment } \\
\text { index } \\
\end{array}$} & \multicolumn{2}{|c|}{$\begin{array}{c}\text { Potential } \\
\text { Recruitment } \\
\text { index }\end{array}$} \\
\hline & & Mean & $\mathrm{SE}$ & Mean & $\mathrm{SE}$ & Mean & SE & Mean & SE & Mean & SE & Mean & SE & Mean & $\mathrm{SE}$ \\
\hline Low $\left(<11 \%{ }^{\mathrm{a}}\right)$ & 8 & 8.3 & 0.55 & 0.20 & 0.08 & 0.20 & 0.08 & 0.13 & 0.04 & 0.13 & 0.04 & 1.17 & 0.39 & 1.19 & 0.39 \\
\hline Moderate (11-15\%) & 7 & 12.8 & 0.46 & 0.51 & 0.04 & 0.53 & 0.03 & 0.37 & 0.04 & 0.42 & 0.05 & 2.87 & 0.36 & 3.09 & 0.28 \\
\hline High $(>15 \%)$ & 7 & 21.9 & 2.25 & 0.34 & 0.05 & 0.38 & 0.05 & 0.26 & 0.05 & 0.29 & 0.04 & 2.09 & 0.31 & 2.29 & 0.32 \\
\hline $\begin{array}{l}\text { Moderate and high } \\
\text { combined }(>11 \%)\end{array}$ & 14 & 17.3 & 1.67 & 0.42 & 0.04 & 0.45 & 0.03 & 0.32 & 0.03 & 0.35 & 0.04 & 2.48 & 0.26 & 2.69 & 0.23 \\
\hline
\end{tabular}

${ }^{\mathrm{a}}$ Percent dry carcass fat 


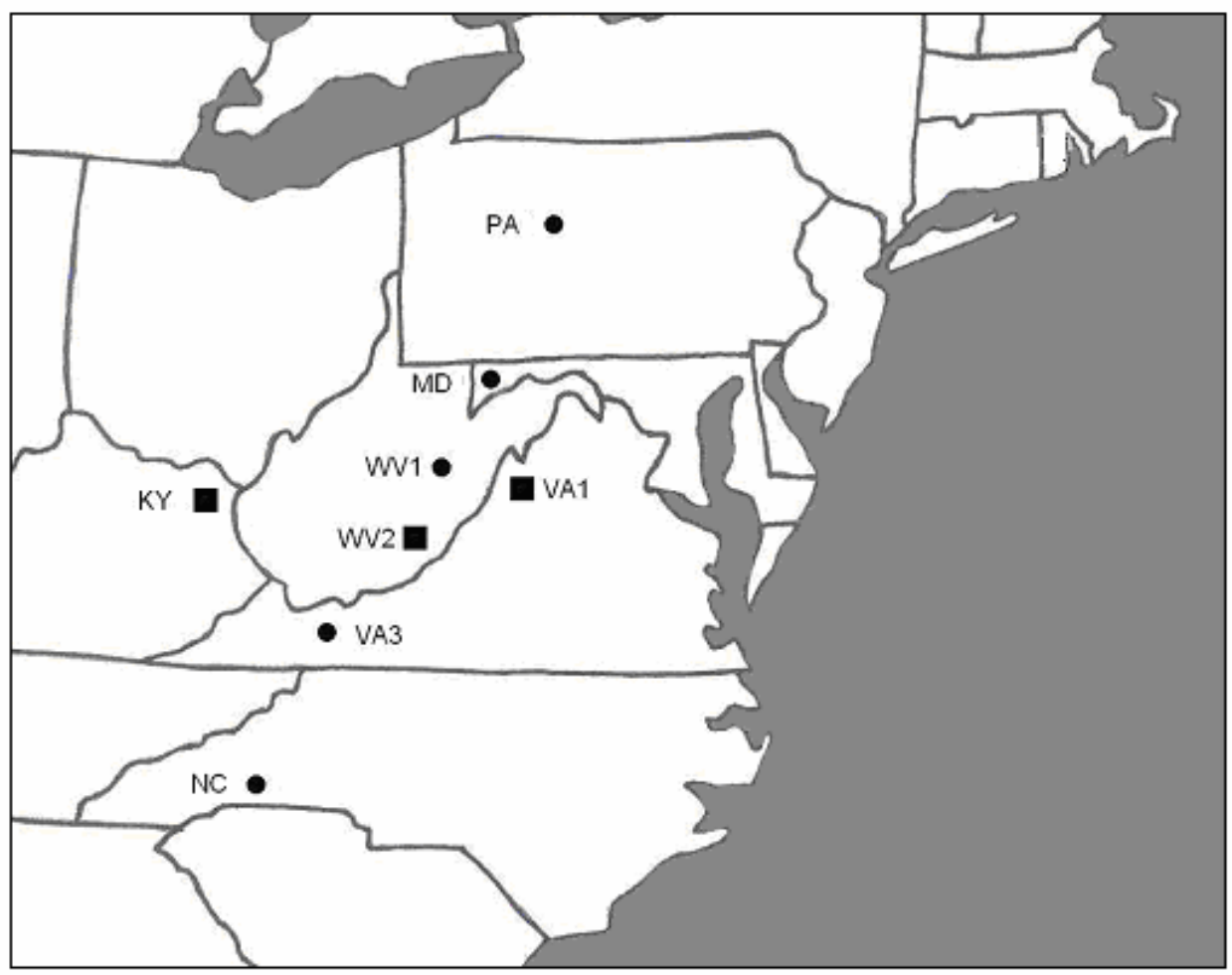

Figure 1. Locations of Appalachian Cooperative Grouse Research Project study sites used in this research in 2000-2002. Square markers identify study sites having oak-hickory forests; circles identify study sites having mixed-mesophytic forests. Study site abbreviations and collection dates are: PA = Pennsylvania (28 March - 3 April); MD = Maryland (23 March - 29 March); WV1 = West Virginia 1 (21 March - 27 March); WV2 = West Virginia 2 (19 March - 25 March); VA1 = Virginia 1 (21 March - 27 March); VA3 = Virginia 3 (25 March - 19 March); KY = Kentucky (13 March - 9 March); NC = North Carolina (13 March - 19 March). 


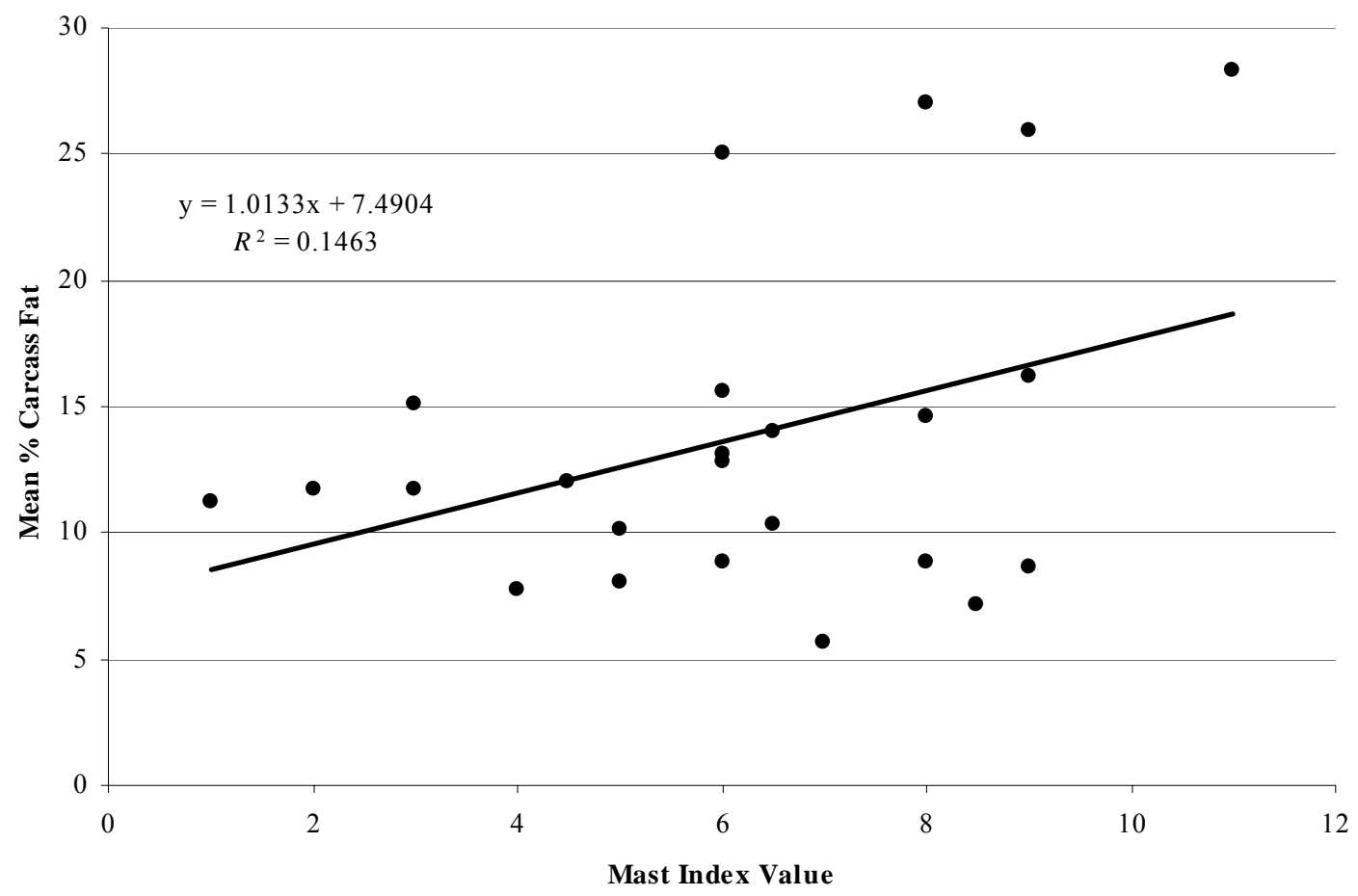

Figure 2. Relation between the Mast Index (sum of the rankings of red/black oak, white oak, chestnut oak, and beech production as none [0], light [1], moderate [2], or heavy [3]) and mean pre-breeding carcass fat (\%) of female ruffed grouse on 8 sites in the central and southern Appalachians, 2000-2002 $(n=24)$. 


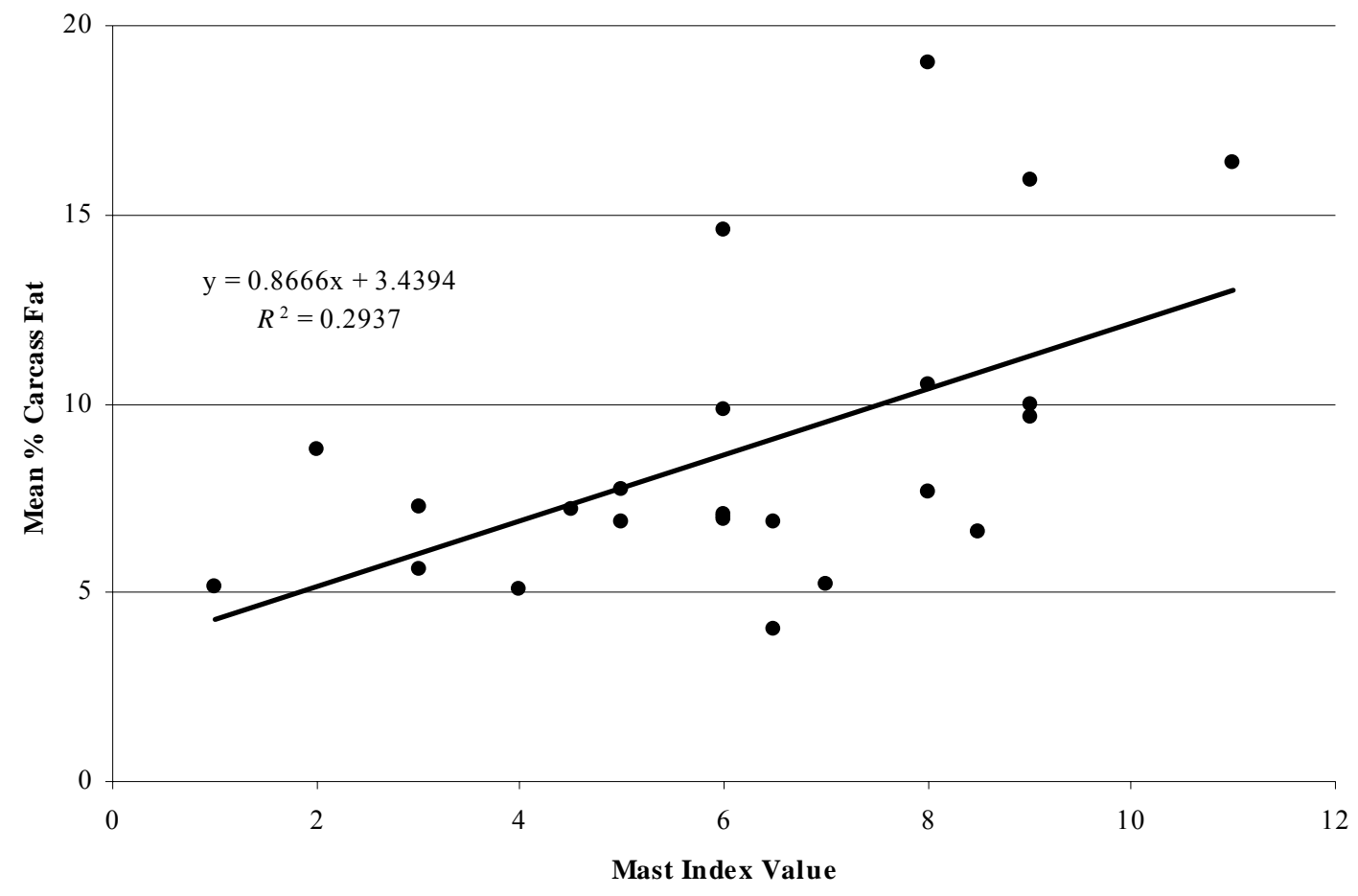

Figure 3. Relation between the Mast Index (sum of the rankings of red/black oak, white oak, chestnut oak, and beech production as none [0], light [1], moderate [2], or heavy [3]) and mean pre-breeding carcass fat (\%) of male ruffed grouse on 8 sites in the central and southern Appalachians, 2000-2002 $(n=24)$. 


\section{APPENDIX TABLES}

Table A.1. Percent aggregate mass, frequency of occurrence, and Importance Values (IV) $)^{\mathrm{a}}$ of forages from crops of ruffed grouse collected in March and April, 2000-2002 in Michigan, Wisconsin, and Minnesota (Northern) and 8 study sites in the central and southern Appalachians. Only forages with IV $>0.05$ in at least 1 year are presented. Abbreviations are 1.=leaves, fl.=flowers, c. $=$ catkins, bt. $=$ buds and twigs, fr. $=$ fruit.

\begin{tabular}{|c|c|c|c|c|c|c|c|c|c|c|}
\hline \multirow{3}{*}{$\begin{array}{l}\text { Site }^{c} \\
\quad \text { Forage }\end{array}$} & \multicolumn{9}{|c|}{ Year } & \multirow[b]{3}{*}{ Mean IV } \\
\hline & \multicolumn{3}{|c|}{2000} & \multicolumn{3}{|c|}{2001} & \multicolumn{3}{|c|}{2002} & \\
\hline & $\%$ mass & Freq & IV & $\%$ mass & Freq & IV & $\%$ mass & Freq & IV & \\
\hline Northern $(n)$ & & $(32)$ & & & $(31)$ & & & $(12)$ & & \\
\hline Aspen fl. (Populus spp.) & 43.6 & 11 & 0.39 & 49.9 & 10 & 0.41 & 37.5 & 4 & 0.35 & 0.38 \\
\hline Strawberry 1. (Fragaria spp.) & 9.2 & 12 & 0.23 & 4.8 & 10 & 0.19 & 10.8 & 7 & 0.35 & 0.25 \\
\hline Pyrola spp. 1. & 11.6 & 6 & 0.15 & 2.9 & 4 & 0.08 & 7.1 & 2 & 0.12 & 0.12 \\
\hline Animal matter & 0.1 & 3 & 0.05 & 0.9 & 15 & 0.25 & 0.0 & 0 & 0.00 & 0.10 \\
\hline Avens 1. (Geum spp.) & 1.6 & 4 & 0.07 & 1.1 & 6 & 0.10 & 6.8 & 2 & 0.12 & 0.10 \\
\hline Cinquefoil 1. (Potentilla spp.) & 4.1 & 5 & 0.10 & 1.2 & 7 & 0.12 & 0.0 & 0 & 0.00 & 0.07 \\
\hline Alder c. (Alnus spp.) & 0.0 & 0 & 0.00 & 0.0 & 0 & 0.00 & 15.6 & 2 & 0.16 & 0.05 \\
\hline Black birch bt. (Betula lenta) & 0.0 & 0 & 0.00 & 18.0 & 2 & 0.12 & 0.0 & 0 & 0.00 & 0.04 \\
\hline Oak fr. (Quercus spp.) & 0.0 & 0 & 0.00 & 0.0 & 0 & 0.00 & 1.2 & 2 & 0.09 & 0.03 \\
\hline Hornbeam c. (Ostrya virginiana) & 0.0 & 0 & 0.00 & 0.0 & 0 & 0.00 & 3.6 & 1 & 0.06 & 0.02 \\
\hline Wintergreen 1. (Gaultheria procumbens) & 0.0 & 0 & 0.00 & 0.5 & 3 & 0.05 & 0.0 & 0 & 0.00 & 0.02 \\
\hline Clover 1. (Trifolium spp.) & 0.5 & 3 & 0.05 & 0.0 & 0 & 0.00 & 0.0 & 0 & 0.00 & 0.02 \\
\hline$\%$ Identified $^{\mathrm{b}}$ & 71.3 & & & 89.6 & & & 82.7 & & & \\
\hline
\end{tabular}

(Continued on next page) 
Table A.1. Continued.

\begin{tabular}{|c|c|c|c|c|c|c|c|c|c|c|}
\hline \multirow{3}{*}{$\begin{array}{l}\text { Site }^{c} \\
\quad \text { Forage }\end{array}$} & \multicolumn{9}{|c|}{ Year } & \multirow[b]{3}{*}{ Mean IV } \\
\hline & \multicolumn{3}{|c|}{2000} & \multicolumn{3}{|c|}{2001} & \multicolumn{3}{|c|}{2002} & \\
\hline & $\%$ mass & Freq & IV & $\%$ mass & Freq & IV & $\%$ mass & Freq & IV & \\
\hline $\mathrm{PA}(n)$ & & $(17)$ & & & $(13)$ & & & $(13)$ & & \\
\hline Oak fr. & 0.0 & 0 & 0.00 & 2.2 & 1 & 0.05 & 78.3 & 6 & 0.62 & 0.22 \\
\hline Blueberry / huckleberry bt. (Vaccinium & & & & & & & & & & \\
\hline Gaylussacia spp.) & 8.0 & 4 & 0.16 & 5.8 & 7 & 0.30 & 1.1 & 5 & 0.20 & 0.22 \\
\hline Coltsfoot fl. (Tussilago farfara) & 1.0 & 1 & 0.03 & 9.0 & 4 & 0.20 & 10.2 & 5 & 0.24 & 0.16 \\
\hline Cinquefoil 1. & 2.1 & 4 & 0.13 & 9.5 & 6 & 0.28 & 0.1 & 1 & 0.04 & 0.15 \\
\hline Avens 1. & 3.0 & 3 & 0.10 & 26.8 & 3 & 0.25 & 0.1 & 2 & 0.08 & 0.14 \\
\hline Sumac fr. (Rhus spp.) & 15.2 & 3 & 0.16 & 0.8 & 3 & 0.12 & 0.5 & 2 & 0.08 & 0.12 \\
\hline Black birch c. & 19.3 & 6 & 0.27 & 0.0 & 0 & 0.00 & 0.3 & 1 & 0.04 & 0.10 \\
\hline Aspen fl. & 16.2 & 7 & 0.29 & 0.0 & 0 & 0.00 & 0.0 & 0 & 0.00 & 0.10 \\
\hline Serviceberry bt. (Amelanchier spp.) & 11.4 & 2 & 0.12 & 3.8 & 2 & 0.10 & 0.2 & 1 & 0.04 & 0.08 \\
\hline Black birch bt. & 3.0 & 4 & 0.13 & 0.0 & 1 & 0.04 & 0.1 & 1 & 0.04 & 0.07 \\
\hline Partridgeberry 1. (Mitchella repens) & 0.0 & 0 & 0.00 & 1.3 & 2 & 0.08 & 1.2 & 3 & 0.12 & 0.07 \\
\hline Wood fern 1. (Dryopteris camyloptera) & 0.0 & 0 & 0.00 & 0.1 & 2 & 0.08 & 0.9 & 3 & 0.12 & 0.07 \\
\hline Animal matter & 0.1 & 1 & 0.03 & 0.0 & 1 & 0.04 & 0.1 & 3 & 0.12 & 0.06 \\
\hline Maple fr. (Acer spp.) & 0.1 & 1 & 0.03 & 9.9 & 1 & 0.09 & 0.0 & 1 & 0.04 & 0.05 \\
\hline Mountain laurel 1. (Kalmia latifolia) & 0.0 & 0 & 0.00 & 5.3 & 3 & 0.14 & 0.0 & 0 & 0.00 & 0.05 \\
\hline Trailing arbutus 1. (Epigaea repens) & 0.2 & 1 & 0.03 & 0.0 & 0 & 0.00 & 3.1 & 2 & 0.09 & 0.04 \\
\hline Cherry bt. (Prunus spp.) & 4.0 & 2 & 0.08 & 0.7 & 1 & 0.04 & 0.0 & 0 & 0.00 & 0.04 \\
\hline Dewberry 1. (Rubus hispidus) & 3.3 & 2 & 0.08 & 0.0 & 0 & 0.00 & 1.1 & 1 & 0.04 & 0.04 \\
\hline Hawkweed 1. (Hieracium spp.) & 0.0 & 0 & 0.00 & 0.6 & 2 & 0.08 & 0.1 & 1 & 0.04 & 0.04 \\
\hline Wintergreen fr. & 0.0 & 0 & 0.00 & 1.4 & 2 & 0.08 & 0.0 & 0 & 0.00 & 0.03 \\
\hline Wintergreen 1. & 0.0 & 0 & 0.00 & 0.5 & 2 & 0.08 & 0.0 & 0 & 0.00 & 0.03 \\
\hline Grape fr. (Vitis spp.) & 0.0 & 0 & 0.00 & 6.0 & 1 & 0.07 & 0.0 & 0 & 0.00 & 0.02 \\
\hline Beech fr. (Fagus grandifolia) & 0.0 & 0 & 0.00 & 2.8 & 1 & 0.05 & 0.0 & 0 & 0.00 & 0.02 \\
\hline Greenbrier fr. (Smilax spp.) & 3.5 & 1 & 0.05 & 0.0 & 0 & 0.00 & 0.0 & 0 & 0.00 & 0.02 \\
\hline$\%$ Identified & 90.5 & & & 87.3 & & & 97.6 & & & \\
\hline
\end{tabular}

(Continued on next page) 
Table A.1. Continued.

\begin{tabular}{|c|c|c|c|c|c|c|c|c|c|c|}
\hline \multirow{3}{*}{$\begin{array}{l}\text { Site }^{c} \\
\quad \text { Forage }\end{array}$} & \multicolumn{9}{|c|}{ Year } & \multirow[b]{3}{*}{ Mean IV } \\
\hline & \multicolumn{3}{|c|}{2000} & \multicolumn{3}{|c|}{2001} & \multicolumn{3}{|c|}{2002} & \\
\hline & $\%$ mass & Freq & IV & $\%$ mass & Freq & IV & $\%$ mass & Freq & IV & \\
\hline $\mathrm{MD}(n)$ & & $(18)$ & & & $(9)$ & & & $(5)$ & & \\
\hline Wood fern 1 & 3.7 & 5 & 0.16 & 3.0 & 3 & 0.18 & 8.9 & 3 & 0.34 & 0.23 \\
\hline Cinquefoil 1. & 6.6 & 5 & 0.17 & 9.4 & 5 & 0.32 & 7.5 & 1 & 0.14 & 0.21 \\
\hline Birdsfoot-trefoil 1. (Lotus corniculatus) & 0.3 & 1 & 0.03 & 9.9 & 5 & 0.33 & 6.0 & 2 & 0.23 & 0.20 \\
\hline Avens 1. & 0.1 & 1 & 0.03 & 0.0 & 0 & 0.00 & 26.1 & 3 & 0.43 & 0.15 \\
\hline Christmas fern 1. (Polystichum acrostichoides) & 5.2 & 3 & 0.11 & 2.5 & 1 & 0.07 & 7.0 & 2 & 0.23 & 0.14 \\
\hline Black birch bt. & 3.6 & 1 & 0.05 & 9.6 & 4 & 0.27 & 0.0 & 0 & 0.00 & 0.11 \\
\hline Oak fr. & 1.7 & 1 & 0.04 & 0.0 & 0 & 0.00 & 30.7 & 1 & 0.25 & 0.10 \\
\hline Strawberry 1. & 2.1 & 2 & 0.07 & 5.6 & 2 & 0.14 & 0.0 & 0 & 0.00 & 0.07 \\
\hline Cherry fr. & 2.1 & 1 & 0.04 & 17.8 & 1 & 0.14 & 0.0 & 0 & 0.00 & 0.06 \\
\hline Maple fr. & 3.6 & 1 & 0.05 & 16.0 & 1 & 0.14 & 0.0 & 0 & 0.00 & 0.06 \\
\hline Animal matter & 0.1 & 2 & 0.06 & 0.0 & 0 & 0.00 & 0.5 & 1 & 0.10 & 0.05 \\
\hline Sorrel 1. (Rumex acetosella) & 1.4 & 3 & 0.09 & 0.3 & 1 & 0.06 & 0.0 & 0 & 0.00 & 0.05 \\
\hline Black birch c. & 14.4 & 1 & 0.10 & 0.0 & 0 & 0.00 & 0.0 & 0 & 0.00 & 0.03 \\
\hline Coltsfoot fl. & 8.4 & 2 & 0.10 & 0.0 & 0 & 0.00 & 0.0 & 0 & 0.00 & 0.03 \\
\hline Serviceberry bt. & 0.4 & 1 & 0.03 & 0.2 & 1 & 0.06 & 0.0 & 0 & 0.00 & 0.03 \\
\hline Sumac fr. & 0.0 & 0 & 0.00 & 0.2 & 1 & 0.06 & 0.0 & 0 & 0.00 & 0.02 \\
\hline$\%$ identified & 54.2 & & & 74.3 & & & 86.7 & & & \\
\hline
\end{tabular}


Table A.1. Continued.

\begin{tabular}{|c|c|c|c|c|c|c|c|c|c|c|}
\hline \multirow{3}{*}{$\begin{array}{l}\text { Site }^{c} \\
\quad \text { Forage }\end{array}$} & \multicolumn{9}{|c|}{ Year } & \multirow[b]{3}{*}{ Mean IV } \\
\hline & \multicolumn{3}{|c|}{2000} & \multicolumn{3}{|c|}{2001} & \multicolumn{3}{|c|}{2002} & \\
\hline & $\%$ mass & Freq & IV & $\%$ mass & Freq & IV & $\%$ mass & Freq & IV & \\
\hline WV1 $(n)$ & & (14) & & & $(8)$ & & & $(15)$ & & \\
\hline Mountain laurel 1. & 16.9 & 4 & 0.23 & 40.9 & 3 & 0.39 & 3.3 & 2 & 0.08 & 0.23 \\
\hline Wood fern 1. & 0.1 & 2 & 0.07 & 4.1 & 5 & 0.33 & 1.2 & 1 & 0.04 & 0.15 \\
\hline Clover 1. & 4.8 & 3 & 0.13 & 3.1 & 2 & 0.14 & 7.9 & 4 & 0.17 & 0.15 \\
\hline Hawkweed 1. & 1.0 & 2 & 0.08 & 6.8 & 3 & 0.22 & 1.5 & 3 & 0.11 & 0.14 \\
\hline Cinquefoil 1. & 3.0 & 5 & 0.19 & 0.8 & 2 & 0.13 & 1.2 & 2 & 0.07 & 0.13 \\
\hline Greenbrier fr. & 20.1 & 4 & 0.24 & 0.0 & 0 & 0.00 & 2.6 & 2 & 0.08 & 0.11 \\
\hline Mountain laurel bt. & 10.6 & 4 & 0.20 & 0.3 & 1 & 0.06 & 0.2 & 1 & 0.03 & 0.10 \\
\hline Dewberry 1. & 0.6 & 1 & 0.04 & 13.5 & 3 & 0.25 & 0.0 & 0 & 0.00 & 0.10 \\
\hline Sumac fr. & 0.0 & 0 & 0.00 & 8.2 & 1 & 0.10 & 7.4 & 3 & 0.14 & 0.08 \\
\hline Black birch c. & 21.8 & 3 & 0.22 & 0.0 & 0 & 0.00 & 0.0 & 0 & 0.00 & 0.07 \\
\hline Coltsfoot fl. & 0.0 & 0 & 0.00 & 0.0 & 0 & 0.00 & 17.1 & 3 & 0.19 & 0.06 \\
\hline Wintergreen fr. & 0.5 & 1 & 0.04 & 1.1 & 1 & 0.07 & 7.5 & 1 & 0.07 & 0.06 \\
\hline Multiflora rose 1. (Rosa multiflora) & 2.2 & 3 & 0.12 & 0.0 & 0 & 0.00 & 4.3 & 1 & 0.05 & 0.06 \\
\hline Greenbrier 1. & 0.0 & 1 & 0.04 & 0.3 & 1 & 0.06 & 0.8 & 2 & 0.07 & 0.06 \\
\hline Christmas fern 1. & 0.0 & 0 & 0.00 & 0.2 & 2 & 0.13 & 1.3 & 1 & 0.04 & 0.06 \\
\hline Black birch bt. & 2.0 & 4 & 0.15 & 0.0 & 0 & 0.00 & 0.0 & 0 & 0.00 & 0.05 \\
\hline Yellow Birch c. (Betula alleghaniensis) & 0.0 & 0 & 0.00 & 5.2 & 2 & 0.15 & 0.0 & 0 & 0.00 & 0.05 \\
\hline Beech fr. & 0.0 & 0 & 0.00 & 2.8 & 2 & 0.14 & 0.0 & 0 & 0.00 & 0.05 \\
\hline Blueberry / huckleberry bt. & 1.1 & 2 & 0.08 & 0.0 & 0 & 0.00 & 0.9 & 1 & 0.04 & 0.04 \\
\hline Oak fr. & 0.0 & 0 & 0.00 & 0.0 & 0 & 0.00 & 15.1 & 1 & 0.11 & 0.04 \\
\hline Serviceberry bt. & 1.6 & 1 & 0.04 & 0.0 & 0 & 0.00 & 4.9 & 1 & 0.06 & 0.03 \\
\hline Witch-hazel fr. (Hamamelis virginiana) & 0.0 & 0 & 0.00 & 0.6 & 1 & 0.07 & 0.0 & 0 & 0.00 & 0.02 \\
\hline Cherry bt. & 0.0 & 0 & 0.00 & 0.5 & 1 & 0.06 & 0.0 & 0 & 0.00 & 0.02 \\
\hline Witch-hazel bt. & 0.0 & 0 & 0.00 & 0.0 & 0 & 0.00 & 2.9 & 1 & 0.05 & 0.02 \\
\hline$\%$ Identified & 87.0 & & & 88.4 & & & 83.7 & & & \\
\hline
\end{tabular}

(Continued on next page) 
Table A.1. Continued.

\begin{tabular}{|c|c|c|c|c|c|c|c|c|c|c|}
\hline \multirow{3}{*}{$\begin{array}{l}\text { Site }^{c} \\
\quad \text { Forage }\end{array}$} & \multicolumn{9}{|c|}{ Year } & \multirow[b]{3}{*}{ Mean IV } \\
\hline & \multicolumn{3}{|c|}{2000} & \multicolumn{3}{|c|}{2001} & \multicolumn{3}{|c|}{2002} & \\
\hline & $\%$ mass & Freq & IV & $\%$ mass & Freq & IV & $\%$ mass & Freq & IV & \\
\hline $\mathrm{WV} 2(n)$ & & (13) & & & (10) & & & (14) & & \\
\hline Cinquefoil 1. & 3.0 & 6 & 0.25 & 4.6 & 6 & 0.32 & 5.8 & 10 & 0.39 & 0.32 \\
\hline Oak fr. & 65.0 & 5 & 0.52 & 11.8 & 1 & 0.11 & 5.2 & 4 & 0.17 & 0.27 \\
\hline Mountain laurel 1. & 1.8 & 3 & 0.12 & 0.2 & 3 & 0.15 & 27.9 & 8 & 0.43 & 0.23 \\
\hline Blueberry / huckleberry bt. & 4.3 & 6 & 0.25 & 1.1 & 2 & 0.11 & 8.1 & 5 & 0.22 & 0.19 \\
\hline Maple fr. & 0.0 & 0 & 0.00 & 19.9 & 7 & 0.45 & 0.1 & 1 & 0.04 & 0.16 \\
\hline Witch-hazel fr. & 0.0 & 0 & 0.00 & 24.3 & 7 & 0.47 & 0.0 & 0 & 0.00 & 0.16 \\
\hline Hawkweed 1. & 0.0 & 0 & 0.00 & 4.8 & 6 & 0.32 & 0.4 & 3 & 0.11 & 0.14 \\
\hline Mountain laurel bt. & 4.8 & 3 & 0.14 & 0.0 & 0 & 0.00 & 15.2 & 4 & 0.22 & 0.12 \\
\hline Greenbrier fr. & 6.1 & 1 & 0.07 & 10.3 & 3 & 0.20 & 0.0 & 0 & 0.00 & 0.09 \\
\hline Coltsfoot fl. & 0.2 & 1 & 0.04 & 0.4 & 1 & 0.05 & 6.9 & 3 & 0.14 & 0.08 \\
\hline Clover 1. & 1.1 & 2 & 0.08 & 0.0 & 0 & 0.00 & 6.6 & 3 & 0.14 & 0.07 \\
\hline Grape fr. & 0.0 & 0 & 0.00 & 14.0 & 2 & 0.17 & 0.1 & 1 & 0.04 & 0.07 \\
\hline Christmas fern 1. & 2.0 & 2 & 0.09 & 0.7 & 1 & 0.05 & 0.0 & 1 & 0.04 & 0.06 \\
\hline Partridgeberry 1. & 0.0 & 0 & 0.00 & 0.0 & 0 & 0.00 & 2.7 & 4 & 0.16 & 0.05 \\
\hline Greenbrier 1. & 0.0 & 0 & 0.00 & 0.0 & 0 & 0.00 & 2.6 & 4 & 0.16 & 0.05 \\
\hline Wintergreen fr. & 0.0 & 0 & 0.00 & 0.1 & 1 & 0.05 & 3.8 & 2 & 0.09 & 0.05 \\
\hline Trailing arbutus 1. (Epigaea repens) & 1.4 & 1 & 0.05 & 0.2 & 1 & 0.05 & 0.2 & 1 & 0.04 & 0.04 \\
\hline Animal matter & 0.0 & 0 & 0.00 & 0.2 & 1 & 0.05 & 0.2 & 2 & 0.07 & 0.04 \\
\hline Serviceberry bt. & 0.0 & 0 & 0.00 & 0.0 & 0 & 0.00 & 4.3 & 1 & 0.06 & 0.02 \\
\hline Witch-hazel bt. & 0.0 & 0 & 0.00 & 0.0 & 0 & 0.00 & 4.3 & 1 & 0.06 & 0.02 \\
\hline$\%$ Identified & 90.8 & & & 92.4 & & & 97.3 & & & \\
\hline
\end{tabular}

(Continued on next page) 
Table A.1. Continued.

\begin{tabular}{|c|c|c|c|c|c|c|c|c|c|c|}
\hline \multirow{3}{*}{$\begin{array}{l}\text { Site }^{c} \\
\quad \text { Forage }\end{array}$} & \multicolumn{9}{|c|}{ Year } & \multirow[b]{3}{*}{ Mean IV } \\
\hline & \multicolumn{3}{|c|}{2000} & \multicolumn{3}{|c|}{2001} & \multicolumn{3}{|c|}{2002} & \\
\hline & $\%$ mass & Freq & IV & $\%$ mass & Freq & IV & $\%$ mass & Freq & IV & \\
\hline VA1 $(n)$ & & $(16)$ & & & $(22)$ & & & $(15)^{1}$ & & \\
\hline Oak fr. & 60.8 & 5 & 0.46 & 1.1 & 1 & 0.03 & 5.3 & 2 & 0.09 & 0.19 \\
\hline Cinquefoil 1. & 0.2 & 1 & 0.03 & 1.1 & 9 & 0.21 & 4.1 & 8 & 0.29 & 0.18 \\
\hline Mountain laurel 1. & 0.8 & 3 & 0.10 & 5.9 & 7 & 0.19 & 11.0 & 4 & 0.19 & 0.16 \\
\hline Christmas fern 1 . & 0.1 & 3 & 0.09 & 6.6 & 2 & 0.08 & 5.6 & 7 & 0.26 & 0.14 \\
\hline Greenbrier 1. & 1.7 & 8 & 0.26 & 2.5 & 3 & 0.08 & 0.0 & 1 & 0.03 & 0.12 \\
\hline Coltsfoot fl. & 9.3 & 6 & 0.23 & 0.7 & 2 & 0.05 & 1.5 & 2 & 0.07 & 0.12 \\
\hline Partridgeberry 1. & 0.0 & 0 & 0.00 & 0.0 & 0 & 0.00 & 2.9 & 9 & 0.31 & 0.10 \\
\hline Serviceberry bt. & 1.8 & 1 & 0.04 & 5.8 & 2 & 0.07 & 5.2 & 4 & 0.16 & 0.09 \\
\hline Blueberry / huckleberry bt. & 0.0 & 1 & 0.03 & 1.5 & 5 & 0.12 & 2.4 & 3 & 0.11 & 0.09 \\
\hline Greenbrier fr. & 10.8 & 2 & 0.12 & 5.2 & 3 & 0.09 & 0.0 & 0 & 0.00 & 0.07 \\
\hline Wintergreen fr. & 0.0 & 0 & 0.00 & 0.5 & 3 & 0.07 & 7.3 & 3 & 0.14 & 0.07 \\
\hline Trailing arbutus 1. & 0.7 & 2 & 0.07 & 2.2 & 1 & 0.03 & 2.6 & 2 & 0.08 & 0.06 \\
\hline Hawkweed 1. & 0.5 & 2 & 0.06 & 0.3 & 3 & 0.07 & 1.5 & 1 & 0.04 & 0.06 \\
\hline Clover 1. & 0.2 & 1 & 0.03 & 8.2 & 4 & 0.13 & 0.0 & 0 & 0.00 & 0.05 \\
\hline Birdfoot-trefoil 1. & 0.0 & 0 & 0.00 & 0.5 & 2 & 0.05 & 1.2 & 3 & 0.11 & 0.05 \\
\hline Wood fern 1 & 0.0 & 0 & 0.00 & 0.1 & 1 & 0.02 & 2.1 & 3 & 0.11 & 0.04 \\
\hline Mountain laurel bt. & 0.1 & 2 & 0.06 & 0.2 & 1 & 0.02 & 0.1 & 1 & 0.03 & 0.04 \\
\hline Witch-hazel bt. & 0.0 & 0 & 0.00 & 0.0 & 0 & 0.00 & 3.9 & 3 & 0.12 & 0.04 \\
\hline Viburnum spp. fr. & 0.0 & 0 & 0.00 & 13.8 & 2 & 0.11 & 0.0 & 0 & 0.00 & 0.04 \\
\hline Avens 1. & 0.0 & 0 & 0.00 & 0.0 & 0 & 0.00 & 1.7 & 3 & 0.11 & 0.04 \\
\hline Multiflora rose 1. & 0.0 & 0 & 0.00 & 2.7 & 2 & 0.06 & 2.1 & 1 & 0.04 & 0.03 \\
\hline Black birch c. & 4.9 & 1 & 0.06 & 0.0 & 0 & 0.00 & 0.6 & 1 & 0.04 & 0.03 \\
\hline Hornbeam c. & 0.0 & 0 & 0.00 & 0.0 & 0 & 0.00 & 3.9 & 2 & 0.09 & 0.03 \\
\hline Witch-hazel fr. & 0.0 & 0 & 0.00 & 7.4 & 2 & 0.08 & 0.0 & 0 & 0.00 & 0.03 \\
\hline Maple fr. & 0.0 & 0 & 0.00 & 1.2 & 3 & 0.07 & 0.0 & 0 & 0.00 & 0.02 \\
\hline Black birch bt. & 0.0 & 0 & 0.00 & 4.1 & 2 & 0.07 & 0.0 & 0 & 0.00 & 0.02 \\
\hline Dewberry 1. & 0.0 & 0 & 0.00 & 7.1 & 1 & 0.06 & 0.0 & 0 & 0.00 & 0.02 \\
\hline$\%$ Identified & 91.7 & & & 83.7 & & & 79.9 & & & \\
\hline
\end{tabular}

(Continued on next page) 
Table A.1. Continued.

\begin{tabular}{|c|c|c|c|c|c|c|c|c|c|c|}
\hline \multirow{3}{*}{$\begin{array}{l}\text { Site }^{c} \\
\quad \text { Forage }\end{array}$} & \multicolumn{9}{|c|}{ Year } & \multirow[b]{3}{*}{ Mean IV } \\
\hline & \multicolumn{3}{|c|}{2000} & \multicolumn{3}{|c|}{2001} & \multicolumn{3}{|c|}{2002} & \\
\hline & $\%$ mass & Freq & IV & $\%$ mass & Freq & IV & $\%$ mass & Freq & IV & \\
\hline VA3 $(n)$ & & $(21)$ & & & $(14)$ & & & (13) & & \\
\hline Oak fr. & 23.5 & 3 & 0.19 & 0.0 & 0 & 0.00 & 90.0 & 11 & 0.87 & 0.35 \\
\hline Cinquefoil 1. & 1.9 & 5 & 0.13 & 16.3 & 11 & 0.47 & 1.7 & 3 & 0.12 & 0.24 \\
\hline Coltsfoot fl. & 30.3 & 12 & 0.44 & 6.8 & 5 & 0.21 & 1.3 & 1 & 0.05 & 0.23 \\
\hline Christmas fern 1 . & 0.1 & 3 & 0.07 & 12.0 & 8 & 0.35 & 1.9 & 5 & 0.20 & 0.21 \\
\hline Mountain laurel 1. & 4.5 & 3 & 0.09 & 9.5 & 7 & 0.30 & 0.1 & 1 & 0.04 & 0.14 \\
\hline Clover 1. & 3.0 & 2 & 0.06 & 6.3 & 7 & 0.28 & 0.4 & 1 & 0.04 & 0.13 \\
\hline Blueberry / huckleberry bt. & 1.1 & 4 & 0.10 & 4.9 & 5 & 0.20 & 0.1 & 1 & 0.04 & 0.11 \\
\hline Serviceberry bt. & 8.9 & 1 & 0.07 & 20.6 & 1 & 0.14 & 0.0 & 0 & 0.00 & 0.07 \\
\hline Greenbrier 1. & 0.2 & 2 & 0.05 & 0.0 & 0 & 0.00 & 0.2 & 2 & 0.08 & 0.04 \\
\hline Ragwort 1. (Senecio spp.) & 0.0 & 0 & 0.00 & 3.0 & 2 & 0.09 & 0.1 & 1 & 0.04 & 0.04 \\
\hline Maple fr. & 0.1 & 2 & 0.05 & 0.5 & 2 & 0.07 & 0.0 & 0 & 0.00 & 0.04 \\
\hline Mountain laurel bt. & 0.4 & 5 & 0.12 & 0.0 & 0 & 0.00 & 0.0 & 0 & 0.00 & 0.04 \\
\hline Wood fern 1 & 0.0 & 0 & 0.00 & 1.4 & 2 & 0.08 & 0.3 & 1 & 0.04 & 0.04 \\
\hline Greenbrier fr. & 10.8 & 1 & 0.08 & 0.0 & 0 & 0.00 & 0.4 & 1 & 0.04 & 0.04 \\
\hline Trailing arbutus 1 . & 2.9 & 1 & 0.04 & 2.5 & 1 & 0.05 & 0.0 & 0 & 0.00 & 0.03 \\
\hline Strawberry 1. & 3.4 & 2 & 0.06 & 0.0 & 0 & 0.00 & 0.0 & 0 & 0.00 & 0.02 \\
\hline$\%$ Identified & 91.6 & & & 85.2 & & & 97.3 & & & \\
\hline
\end{tabular}

(Continued on next page) 
Table A.1. Continued.

\begin{tabular}{|c|c|c|c|c|c|c|c|c|c|c|}
\hline \multirow{3}{*}{$\begin{array}{l}\text { Site }^{c} \\
\quad \text { Forage }\end{array}$} & \multicolumn{9}{|c|}{ Year } & \multirow[b]{3}{*}{ Mean IV } \\
\hline & \multicolumn{3}{|c|}{2000} & \multicolumn{3}{|c|}{2001} & \multicolumn{3}{|c|}{2002} & \\
\hline & $\%$ mass & Freq & IV & $\%$ mass & Freq & IV & $\%$ mass & Freq & IV & \\
\hline $\mathrm{KY}(n)$ & & $(2)$ & & & $(7)$ & & & (14) & & \\
\hline Beech fr. & 0.0 & 0 & 0.00 & 97.3 & 6 & 0.92 & 0.0 & 0 & 0.0 & 0.31 \\
\hline Christmas fern 1. & 0.0 & 0 & 0.00 & 0.1 & 1 & 0.07 & 10.7 & 6 & 0.27 & 0.11 \\
\hline Multiflora rose 1. & 0.0 & 0 & 0.00 & 0.0 & 0 & 0.00 & 32.3 & 4 & 0.30 & 0.10 \\
\hline Greenbrier 1. & 0.0 & 0 & 0.00 & 0.3 & 1 & 0.07 & 6.8 & 4 & 0.18 & 0.08 \\
\hline Avens 1 & 0.0 & 0 & 0.00 & 0.0 & 0 & 0.00 & 4.4 & 2 & 0.09 & 0.03 \\
\hline Partridgeberry 1. & 0.0 & 0 & 0.00 & 0.0 & 0 & 0.00 & 2.7 & 2 & 0.09 & 0.03 \\
\hline Ragwort 1. & 0.0 & 0 & 0.00 & 0.0 & 0 & 0.00 & 2.4 & 2 & 0.08 & 0.03 \\
\hline Sumac fr. & 0.0 & 0 & 0.00 & 0.0 & 0 & 0.00 & 1.9 & 2 & 0.08 & 0.03 \\
\hline Birdsfoot-trefoil 1. & 0.0 & 0 & 0.00 & 0.0 & 0 & 0.00 & 1.7 & 2 & 0.08 & 0.03 \\
\hline Wood fern 1 & 0.0 & 0 & 0.00 & 0.0 & 0 & 0.00 & 0.4 & 2 & 0.07 & 0.02 \\
\hline Animal matter & 0.0 & 0 & 0.00 & 0.0 & 0 & 0.00 & 0.2 & 2 & 0.07 & 0.02 \\
\hline$\%$ Identified & 0.0 & & & 97.7 & & & 63.7 & & & \\
\hline
\end{tabular}

(Continued on next page) 
Table A.1. Continued.

\begin{tabular}{|c|c|c|c|c|c|c|c|c|c|c|}
\hline \multirow{3}{*}{$\begin{array}{l}\text { Site }^{c} \\
\quad \text { Forage }\end{array}$} & \multicolumn{9}{|c|}{ Year } & \multirow[b]{3}{*}{ Mean IV } \\
\hline & \multicolumn{3}{|c|}{2000} & \multicolumn{3}{|c|}{2001} & \multicolumn{3}{|c|}{2002} & \\
\hline & $\%$ mass & Freq & IV & $\%$ mass & Freq & IV & $\%$ mass & Freq & IV & \\
\hline $\mathrm{NC}(n)$ & & $(17)$ & & & (20) & & & (16) & & \\
\hline Mountain laurel 1. & 28.9 & 8 & 0.38 & 3.4 & 7 & 0.19 & 2.7 & 3 & 0.11 & 0.23 \\
\hline Christmas fern 1. & 0.1 & 3 & 0.09 & 1.0 & 7 & 0.18 & 19.2 & 8 & 0.35 & 0.20 \\
\hline Cinquefoil 1. & 8.0 & 8 & 0.28 & 1.2 & 5 & 0.13 & 8.5 & 4 & 0.17 & 0.19 \\
\hline Clover 1. & 10.1 & 7 & 0.26 & 2.3 & 2 & 0.06 & 15.5 & 5 & 0.23 & 0.18 \\
\hline Oak fr. & 5.9 & 1 & 0.06 & 0.0 & 0 & 0.00 & 16.6 & 4 & 0.21 & 0.09 \\
\hline Strawberry 1. & 4.5 & 2 & 0.08 & 6.3 & 6 & 0.18 & 0.0 & 0 & 0.00 & 0.09 \\
\hline Greenbrier 1. & 0.9 & 1 & 0.03 & 3.0 & 6 & 0.17 & 0.3 & 1 & 0.03 & 0.08 \\
\hline Greenbrier fr. & 0.0 & 0 & 0.00 & 32.7 & 2 & 0.21 & 0.0 & 0 & 0.00 & 0.07 \\
\hline Blueberry / huckleberry bt & 0.0 & 1 & 0.03 & 2.3 & 5 & 0.14 & 1.5 & 1 & 0.04 & 0.07 \\
\hline Wood fern 1 & 1.0 & 3 & 0.09 & 0.9 & 3 & 0.08 & 0.1 & 1 & 0.03 & 0.07 \\
\hline Black birch bt. & 1.3 & 2 & 0.07 & 10.6 & 3 & 0.13 & 0.0 & 0 & 0.00 & 0.06 \\
\hline Serviceberry bt. & 4.7 & 3 & 0.11 & 3.2 & 1 & 0.04 & 0.1 & 1 & 0.03 & 0.06 \\
\hline Black birch c. & 0.0 & 0 & 0.00 & 12.4 & 4 & 0.16 & 0.0 & 0 & 0.00 & 0.05 \\
\hline Sorrel 1. & 0.0 & 0 & 0.00 & 1.4 & 2 & 0.06 & 1.8 & 3 & 0.10 & 0.05 \\
\hline Hawkweed 1. & 0.3 & 1 & 0.03 & 0.9 & 4 & 0.10 & 0.0 & 0 & 0.00 & 0.05 \\
\hline Avens 1. & 5.5 & 3 & 0.12 & 0.0 & 0 & 0.00 & 0.0 & 0 & 0.00 & 0.04 \\
\hline Ragwort 1. & 4.2 & 3 & 0.11 & 0.0 & 0 & 0.00 & 0.0 & 0 & 0.00 & 0.04 \\
\hline Multiflora rose 1 & 2.3 & 1 & 0.04 & 0.0 & 0 & 0.00 & 4.7 & 1 & 0.05 & 0.03 \\
\hline Azalea 1. (Rhododendron spp.) & 0.0 & 0 & 0.00 & 8.2 & 1 & 0.07 & 0.0 & 0 & 0.00 & 0.02 \\
\hline Trailing arbutus 1. & 0.0 & 0 & 0.00 & 0.2 & 2 & 0.05 & 0.0 & 0 & 0.00 & 0.02 \\
\hline Animal matter & 0.0 & 0 & 0.00 & 0.1 & 2 & 0.05 & 0.0 & 0 & 0.00 & 0.02 \\
\hline Mountain laurel bt. & 0.0 & 0 & 0.00 & 0.0 & 2 & 0.05 & 0.0 & 0 & 0.00 & 0.02 \\
\hline
\end{tabular}

${ }^{\mathrm{a}}$ Importance Value $(\mathrm{IV})=($ aggregate $\%$ mass $/ 100+\%$ occurrence $/ 100) / 2$

b $\%$ of total aggregate mass identified to genus or species.

${ }^{\mathrm{c}} \mathrm{PA}=$ Pennsylvania, $\mathrm{MD}=$ Maryland; WV1 = West Virginia 1; WV2 = West Virginia 2; VA1 = Virginia 1; VA3 = Virginia 3; KY $=$ Kentucky; NC $=$ North Carolina. 
Table A.2. Body composition (grams water, lipid, protein, and ash) of ruffed grouse collected in March - April, 2000-2002 in

Michigan, Wisconsin and Minnesota (Northern) and 8 sites in the central and southern Appalachians.

\begin{tabular}{|c|c|c|c|c|c|c|c|c|c|c|c|c|c|c|c|c|c|c|}
\hline \multirow{3}{*}{$\begin{array}{l}\text { Site }^{\mathrm{a}} \\
\qquad \text { Year }\end{array}$} & \multicolumn{9}{|c|}{ Female } & \multicolumn{9}{|c|}{ Male } \\
\hline & \multirow[b]{2}{*}{$n$} & \multicolumn{2}{|c|}{ Moisture } & \multicolumn{2}{|c|}{ Lipid } & \multicolumn{2}{|c|}{ Protein } & \multicolumn{2}{|c|}{ Ash } & \multirow[b]{2}{*}{$n$} & \multicolumn{2}{|c|}{ Moisture } & \multicolumn{2}{|c|}{ Lipid } & \multicolumn{2}{|c|}{ Protein } & \multicolumn{2}{|c|}{ Ash } \\
\hline & & Mean & SE & Mean & $\mathrm{SE}$ & Mean & $\overline{S E}$ & Mean & $\overline{S E}$ & & Mean & $\mathrm{SE}$ & Mean & $\mathrm{SE}$ & Mean & $\mathrm{SE}$ & Mean & $\mathrm{SE}$ \\
\hline \multicolumn{19}{|l|}{ Northern } \\
\hline 2000 & 16 & 261.1 & 4.7 & 8.5 & 1.1 & 77.1 & 1.6 & 12.9 & 0.4 & 16 & 305.6 & 5.1 & 6.5 & 1.0 & 88.4 & 1.7 & 14.1 & 0.3 \\
\hline 2001 & 15 & 244.7 & 4.2 & 6.4 & 1.1 & 71.8 & 1.8 & 12.2 & 0.4 & 18 & 281.5 & 4.5 & 4.4 & 0.5 & 80.8 & 1.8 & 14.0 & 0.2 \\
\hline 2002 & 5 & 229.3 & 7.5 & 7.8 & 3.8 & 76.3 & 3.1 & 12.7 & 0.3 & 10 & 289.2 & 14.1 & 5.7 & 0.6 & 93.2 & 4.9 & 14.7 & 0.6 \\
\hline \multicolumn{19}{|l|}{ PA } \\
\hline 2000 & 8 & 293.8 & 9.7 & 20.9 & 4.6 & 82.7 & 7.6 & 14.0 & 1.3 & 11 & 312.7 & 7.7 & 6.7 & 0.8 & 92.5 & 3.1 & 15.4 & 0.6 \\
\hline 2001 & 7 & 273.1 & 14.4 & 9.9 & 3.4 & 77.5 & 4.0 & 12.7 & 0.7 & 8 & 348.1 & 7.1 & 13.7 & 3.8 & 99.4 & 2.1 & 15.9 & 0.4 \\
\hline 2002 & 8 & 293.5 & 10.7 & 21.1 & 3.8 & 94.3 & 7.3 & 15.3 & 1.3 & 6 & 302.8 & 6.7 & 13.1 & 3.4 & 99.7 & 3.8 & 15.6 & 0.4 \\
\hline \multicolumn{19}{|l|}{$\mathrm{MD}$} \\
\hline 2000 & 7 & 291.6 & 9.1 & 16.8 & 3.7 & 94.0 & 3.5 & 14.4 & 0.6 & 12 & 329.7 & 5.4 & 8.9 & 1.3 & 98.2 & 1.9 & 15.4 & 0.3 \\
\hline 2001 & 7 & 276.9 & 8.1 & 9.6 & 2.2 & 85.5 & 2.2 & 14.0 & 0.5 & 3 & 330.4 & 8.7 & 10.5 & 3.0 & 100.8 & 2.5 & 16.3 & 0.2 \\
\hline 2002 & 5 & 303.8 & 4.1 & 41.9 & 6.3 & 96.3 & 1.0 & 16.4 & 0.3 & 2 & 345.3 & 35.6 & 25.6 & 10.1 & 111.0 & 10.4 & 17.7 & 0.3 \\
\hline \multicolumn{19}{|l|}{ WV1 } \\
\hline 2000 & 6 & 293.2 & 7.6 & 9.1 & 2.1 & 84.1 & 1.9 & 14.0 & 0.5 & 8 & 324.9 & 10.7 & 6.2 & 1.0 & 95.7 & 3.1 & 14.9 & 0.5 \\
\hline 2001 & 6 & 273.3 & 4.2 & 9.6 & 0.9 & 84.9 & 3.0 & 13.3 & 0.4 & 2 & 337.0 & 32.2 & 23.2 & 15.4 & 105.5 & 8.2 & 17.5 & 0.9 \\
\hline 2002 & 10 & 302.9 & 6.0 & 13.6 & 2.1 & 96.6 & 2.3 & 15.6 & 0.4 & 7 & 306.7 & 13.4 & 8.5 & 2.0 & 98.3 & 5.5 & 16.4 & 0.7 \\
\hline \multicolumn{19}{|l|}{ WV2 } \\
\hline 2000 & 5 & 302.1 & 5.7 & 15.5 & 4.0 & 92.0 & 2.2 & 14.9 & 0.7 & 8 & 356.9 & 8.4 & 9.9 & 1.8 & 104.3 & 2.2 & 16.9 & 0.5 \\
\hline 2001 & 7 & 295.6 & 6.2 & 8.6 & 1.2 & 88.5 & 2.2 & 14.4 & 0.6 & 4 & 340.7 & 4.5 & 9.2 & 1.2 & 100.6 & 1.8 & 15.3 & 0.4 \\
\hline 2002 & 6 & 291.9 & 15.7 & 19.0 & 6.5 & 91.9 & 6.2 & 15.4 & 1.2 & 9 & 310.0 & 10.6 & 5.3 & 0.6 & 104.0 & 3.3 & 17.0 & 0.6 \\
\hline
\end{tabular}


Table A.2. Continued

\begin{tabular}{|c|c|c|c|c|c|c|c|c|c|c|c|c|c|c|c|c|c|c|}
\hline \multirow{3}{*}{$\begin{array}{l}\text { Site }^{\mathrm{a}} \\
\quad \text { Year }\end{array}$} & \multicolumn{9}{|c|}{ Female } & \multicolumn{9}{|c|}{ Male } \\
\hline & \multirow[b]{2}{*}{$n$} & \multicolumn{2}{|c|}{ Moisture } & \multicolumn{2}{|c|}{ Lipid } & \multicolumn{2}{|c|}{ Protein } & \multicolumn{2}{|c|}{ Ash } & \multirow[b]{2}{*}{$n$} & \multicolumn{2}{|c|}{ Moisture } & \multicolumn{2}{|c|}{ Lipid } & \multicolumn{2}{|c|}{ Protein } & \multicolumn{2}{|c|}{ Ash } \\
\hline & & Mean & $\mathrm{SE}$ & Mean & $\mathrm{SE}$ & Mean & $\mathrm{SE}$ & Mean & SE & & Mean & SE & Mean & $\mathrm{SE}$ & Mean & SE & Mean & $\mathrm{SE}$ \\
\hline \multicolumn{19}{|l|}{ VA1 } \\
\hline 2000 & 11 & 302.3 & 8.9 & 34.8 & 4.1 & 87.2 & 5.2 & 14.7 & 0.9 & 5 & 351.5 & 14.2 & 13.7 & 2.1 & 108.3 & 5.0 & 16.6 & 0.8 \\
\hline 2001 & 8 & 285.5 & 3.5 & 17.8 & 2.6 & 86.4 & 1.1 & 15.5 & 1.0 & 16 & 323.8 & 10.6 & 14.2 & 1.7 & 98.8 & 2.9 & 16.5 & 0.6 \\
\hline 2002 & 8 & 271.8 & 5.9 & 18.7 & 6.2 & 90.6 & 2.5 & 14.5 & 0.4 & 9 & 318.3 & 11.0 & 9.3 & 1.0 & 104.2 & 3.3 & 17.0 & 0.5 \\
\hline \multicolumn{19}{|l|}{ VA3 } \\
\hline 2000 & 12 & 291.6 & 4.9 & 20.9 & 3.9 & 88.8 & 1.7 & 15.0 & 0.4 & 10 & 327.7 & 12.5 & 9.1 & 1.6 & 95.5 & 3.6 & 15.6 & 0.3 \\
\hline 2001 & 6 & 271.2 & 4.9 & 11.2 & 2.3 & 81.0 & 1.5 & 13.6 & 0.7 & 8 & 324.8 & 6.2 & 8.7 & 1.6 & 93.4 & 1.6 & 16.1 & 0.3 \\
\hline 2002 & 8 & 295.7 & 6.7 & 44.3 & 2.6 & 100.4 & 2.0 & 16.4 & 0.7 & 5 & 349.9 & 12.1 & 32.5 & 4.9 & 116.4 & 4.5 & 18.4 & 0.7 \\
\hline \multicolumn{19}{|l|}{ KY } \\
\hline 2000 & 3 & 290.8 & 15.2 & 14.2 & 2.6 & 86.9 & 4.3 & 15.1 & 0.8 & 1 & 321.8 & & 6.3 & & 99.2 & & 14.8 & \\
\hline 2001 & 2 & 316.0 & 2.9 & 44.7 & 8.9 & 93.3 & 1.2 & 15.3 & 0.1 & 5 & 357.4 & 18.1 & 23.2 & 2.0 & 103.1 & 8.3 & 15.4 & 0.6 \\
\hline 2002 & 6 & 284.2 & 5.0 & 14.6 & 1.8 & 91.9 & 1.9 & 14.7 & 0.5 & 10 & 329.8 & 9.4 & 12.7 & 2.4 & 108.2 & 2.9 & 16.7 & 0.5 \\
\hline \multicolumn{19}{|l|}{$\mathrm{NC}$} \\
\hline 2000 & 8 & 255.5 & 12.5 & 6.0 & 1.4 & 78.5 & 3.9 & 13.3 & 0.6 & 12 & 320.2 & 7.5 & 6.5 & 0.6 & 96.9 & 2.2 & 16.4 & 0.5 \\
\hline 2001 & 9 & 281.5 & 10.6 & 14.6 & 3.6 & 83.9 & 2.8 & 13.7 & 0.3 & 11 & 326.1 & 6.1 & 8.9 & 1.0 & 93.9 & 1.4 & 16.0 & 0.5 \\
\hline 2002 & 7 & 269.9 & 20.7 & 11.3 & 2.4 & 90.9 & 8.6 & 15.3 & 1.2 & 10 & 312.7 & 10.6 & 10.0 & 1.8 & 101.1 & 4.8 & 18.3 & 1.8 \\
\hline
\end{tabular}


Table A.3. Body composition (percent water ${ }^{\mathrm{a}}$, lipid ${ }^{\mathrm{b}}$, protein $^{\mathrm{b}}$, and $\mathrm{ash}^{\mathrm{b}}$ ) of ruffed grouse collected in March - April, 2000-2002 in Michigan, Wisconsin and Minnesota (Northern) and 8 sites in the central and southern Appalachians.

\begin{tabular}{|c|c|c|c|c|c|c|c|c|c|c|c|c|c|c|c|c|c|c|}
\hline \multirow{3}{*}{$\begin{array}{l}\text { Site }^{\mathrm{a}} \\
\qquad \text { Year }\end{array}$} & \multicolumn{9}{|c|}{ Female } & \multicolumn{9}{|c|}{ Male } \\
\hline & \multirow[b]{2}{*}{$n$} & \multicolumn{2}{|c|}{ Moisture } & \multicolumn{2}{|c|}{ Lipid } & \multicolumn{2}{|c|}{ Protein } & \multicolumn{2}{|c|}{ Ash } & \multirow[b]{2}{*}{$n$} & \multicolumn{2}{|c|}{ Moisture } & \multicolumn{2}{|c|}{ Lipid } & \multicolumn{2}{|c|}{ Protein } & \multicolumn{2}{|c|}{ Ash } \\
\hline & & Mean & SE & Mean & SE & Mean & SE & Mean & $\mathrm{SE}$ & & Mean & $\mathrm{SE}$ & Mean & $\mathrm{SE}$ & Mean & $\mathrm{SE}$ & Mean & $\mathrm{SE}$ \\
\hline \multicolumn{19}{|l|}{ Northern } \\
\hline 2000 & 16 & 71.3 & 0.2 & 7.9 & 0.9 & 73.5 & 0.9 & 12.3 & 0.2 & 16 & 72.8 & 0.2 & 5.6 & 0.7 & 77.4 & 0.6 & 12.4 & 0.2 \\
\hline 2001 & 15 & 72.7 & 0.5 & 6.7 & 1.0 & 78.1 & 0.7 & 13.3 & 0.2 & 18 & 73.4 & 0.4 & 4.2 & 0.4 & 79.0 & 0.4 & 13.8 & 0.3 \\
\hline 2002 & 5 & 69.8 & 0.8 & 7.3 & 3.0 & 77.2 & 2.3 & 12.9 & 0.5 & 10 & 71.0 & 0.2 & 4.7 & 0.4 & 78.7 & 0.6 & 12.6 & 0.4 \\
\hline \multicolumn{19}{|l|}{ PA } \\
\hline 2000 & 8 & 69.1 & 1.2 & 15.1 & 2.7 & 69.4 & 1.9 & 11.8 & 0.3 & 11 & 72.6 & 0.2 & 5.6 & 0.5 & 78.2 & 0.7 & 13.1 & 0.3 \\
\hline 2001 & 7 & 72.5 & 0.7 & 8.6 & 2.1 & 75.2 & 2.4 & 12.3 & 0.4 & 8 & 72.3 & 0.6 & 9.7 & 2.3 & 74.9 & 1.8 & 12.0 & 0.4 \\
\hline 2002 & 8 & 69.0 & 1.0 & 16.2 & 2.9 & 70.9 & 2.3 & 11.5 & 0.5 & 6 & 70.0 & 0.7 & 10.0 & 2.5 & 76.9 & 1.9 & 12.1 & 0.4 \\
\hline \multicolumn{19}{|l|}{$\mathrm{MD}$} \\
\hline 2000 & 7 & 69.9 & 0.8 & 12.9 & 2.5 & 75.2 & 2.1 & 11.5 & 0.3 & 12 & 72.5 & 0.4 & 7.0 & 0.9 & 78.4 & 0.7 & 12.4 & 0.2 \\
\hline 2001 & 7 & 70.4 & 0.4 & 8.0 & 1.6 & 73.7 & 2.0 & 12.1 & 0.7 & 3 & 70.9 & 1.1 & 7.7 & 2.1 & 74.4 & 3.3 & 12.0 & 0.4 \\
\hline 2002 & 5 & 65.7 & 0.7 & 25.9 & 2.6 & 61.1 & 2.5 & 10.4 & 0.3 & 2 & 69.1 & 0.9 & 15.9 & 4.2 & 72.0 & 3.7 & 11.6 & 1.5 \\
\hline \multicolumn{19}{|l|}{ WV1 } \\
\hline 2000 & 6 & 71.9 & 0.3 & 7.8 & 1.6 & 73.4 & 1.1 & 12.2 & 0.3 & 8 & 72.9 & 0.1 & 5.1 & 0.7 & 79.2 & 0.5 & 12.3 & 0.2 \\
\hline 2001 & 6 & 71.6 & 0.5 & 8.8 & 0.6 & 78.3 & 1.0 & 12.3 & 0.1 & 2 & 70.1 & 1.8 & 14.6 & 8.0 & 74.2 & 7.8 & 12.4 & 1.6 \\
\hline 2002 & 10 & 69.8 & 0.4 & 10.4 & 1.6 & 73.8 & 0.9 & 11.9 & 0.2 & 7 & 70.9 & 0.3 & 6.9 & 1.7 & 78.2 & 1.8 & 13.1 & 0.5 \\
\hline \multicolumn{19}{|l|}{ WV2 } \\
\hline 2000 & 5 & 70.4 & 0.4 & 12.0 & 3.0 & 72.5 & 1.5 & 11.7 & 0.4 & 8 & 72.2 & 0.3 & 7.2 & 1.3 & 76.1 & 1.2 & 12.3 & 0.3 \\
\hline 2001 & 7 & 71.3 & 0.2 & 7.2 & 0.9 & 74.3 & 0.9 & 12.1 & 0.6 & 4 & 71.1 & 0.9 & 6.6 & 0.7 & 72.8 & 3.1 & 11.1 & 0.6 \\
\hline 2002 & 6 & 69.2 & 1.2 & 14.0 & 4.4 & 71.2 & 3.4 & 11.8 & 0.6 & 9 & 70.1 & 0.5 & 4.1 & 0.4 & 79.0 & 0.6 & 12.9 & 0.2 \\
\hline
\end{tabular}


Table A.3. Continued

\begin{tabular}{|c|c|c|c|c|c|c|c|c|c|c|c|c|c|c|c|c|c|c|}
\hline \multirow{3}{*}{$\begin{array}{l}\text { Site }^{\mathrm{c}} \\
\quad \text { Year }\end{array}$} & \multicolumn{9}{|c|}{ Female } & \multicolumn{9}{|c|}{ Male } \\
\hline & \multirow[b]{2}{*}{$n$} & \multicolumn{2}{|c|}{ Moisture } & \multicolumn{2}{|c|}{ Lipid } & \multicolumn{2}{|c|}{ Protein } & \multicolumn{2}{|c|}{ Ash } & \multirow[b]{2}{*}{$n$} & \multicolumn{2}{|c|}{ Moisture } & \multicolumn{2}{|c|}{ Lipid } & \multicolumn{2}{|c|}{ Protein } & \multicolumn{2}{|c|}{ Ash } \\
\hline & & Mean & $\mathrm{SE}$ & Mean & $\mathrm{SE}$ & Mean & $\mathrm{SE}$ & Mean & $\mathrm{SE}$ & & Mean & $\mathrm{SE}$ & Mean & $\mathrm{SE}$ & Mean & SE & Mean & SE \\
\hline \multicolumn{19}{|l|}{ VA1 } \\
\hline 2000 & 11 & 68.6 & 1.0 & 25.0 & 2.4 & 62.7 & 2.0 & 10.6 & 0.4 & 5 & 71.4 & 1.3 & 9.8 & 1.6 & 77.3 & 1.6 & 11.9 & 0.2 \\
\hline 2001 & 8 & 70.3 & 0.5 & 14.6 & 1.9 & 72.0 & 1.7 & 12.8 & 0.6 & 16 & 71.1 & 0.3 & 10.5 & 1.0 & 75.2 & 0.8 & 12.6 & 0.3 \\
\hline 2002 & 8 & 68.4 & 1.0 & 13.2 & 3.5 & 72.7 & 2.6 & 11.6 & 0.5 & 9 & 70.6 & 0.3 & 6.9 & 0.6 & 78.5 & 0.6 & 12.8 & 0.1 \\
\hline \multicolumn{19}{|l|}{ VA3 } \\
\hline 2000 & 12 & 69.7 & 0.7 & 15.6 & 2.4 & 70.2 & 1.7 & 11.9 & 0.4 & 10 & 72.3 & 0.4 & 7.1 & 1.1 & 76.3 & 0.6 & 12.7 & 0.6 \\
\hline 2001 & 6 & 71.5 & 0.4 & 10.1 & 1.8 & 75.0 & 1.2 & 12.6 & 0.4 & 8 & 72.6 & 0.4 & 6.9 & 1.1 & 76.2 & 0.8 & 13.1 & 0.3 \\
\hline 2002 & 8 & 64.4 & 0.3 & 27.0 & 1.0 & 61.6 & 0.7 & 10.1 & 0.4 & 5 & 67.6 & 0.6 & 19.0 & 2.5 & 69.5 & 2.6 & 11.0 & 0.6 \\
\hline \multicolumn{19}{|l|}{ KY } \\
\hline 2000 & 3 & 69.7 & 0.6 & 11.2 & 1.6 & 68.9 & 1.4 & 12.0 & 0.2 & 1 & 72.2 & & 5.1 & & 80.2 & & 12.0 & \\
\hline 2001 & 2 & 66.8 & 0.9 & 28.3 & 4.3 & 59.5 & 2.1 & 9.8 & 0.5 & 5 & 71.6 & 0.4 & 16.4 & 1.0 & 72.5 & 2.1 & 10.9 & 0.1 \\
\hline 2002 & 6 & 69.4 & 0.4 & 11.7 & 1.5 & 73.5 & 1.6 & 11.7 & 0.4 & 10 & 70.0 & 0.4 & 8.8 & 1.4 & 76.8 & 1.2 & 11.9 & 0.3 \\
\hline \multicolumn{19}{|l|}{$\mathrm{NC}$} \\
\hline 2000 & 8 & 71.5 & 0.4 & 5.6 & 1.0 & 77.2 & 1.0 & 13.2 & 0.5 & 12 & 72.1 & 0.3 & 5.2 & 0.5 & 78.2 & 0.6 & 13.2 & 0.2 \\
\hline 2001 & 9 & 71.0 & 0.5 & 11.7 & 2.2 & 73.4 & 1.7 & 12.1 & 0.5 & 11 & 72.9 & 0.4 & 7.3 & 0.7 & 77.5 & 0.4 & 13.3 & 0.4 \\
\hline 2002 & 7 & 69.4 & 0.7 & 8.8 & 1.3 & 75.6 & 2.0 & 12.9 & 0.4 & 10 & 70.4 & 0.4 & 7.7 & 1.4 & 76.6 & 1.2 & 13.7 & 1.0 \\
\hline
\end{tabular}

${ }^{\mathrm{a}}$ Percent wet carcass mass

${ }^{\mathrm{b}}$ Percent dry carcass mass

${ }^{\mathrm{c}}$ Pennsylvania, MD = Maryland; WV1 = West Virginia 1; WV2 = West Virginia 2; VA1 = Virginia 1; VA3 = Virginia 3; KY = Kentucky; NC = North Carolina. 